\title{
A revision of the Australian species of Parahebe and Derwentia (Scrophulariaceae)
}

\author{
Barbara G. Briggs and F. Ehrendorfer
}

\begin{abstract}
Briggs, Barbara G. ${ }^{1}$ and Ehrendorfer F. ${ }^{2}\left({ }^{1}\right.$ National Herbarium of New South Wales, Royal Botanic Gardens, Sydney, NSW, Australia 2000; ${ }^{2}$ Institut für Botanik, Univ. Wien, Rennweg 14, A-1030 Wien, Austria) 1992. A revision of the Australian species of Parahebe and Derwentia (Scrophulariaceae). Telopea 5 (1): 241-287. The relationships of the Australian species placed in or related to Parahebe $\mathrm{W}$. Oliver are considered. It is concluded, on the basis of phylogenetic analyses to be published elsewhere, that only one Australian species is appropriately referred to Parahebe, namely P. lithophila, which is described as a new species. The genus Derwentia Raf. is revived for a group of eight species restricted to Australia and previously undescribed or referred to Veronica or Parahebe. Derwentia arcuata, D. blakelyi and D. velutina are described as new. Combinations are provided for D. arenaria and D. nivea, both transferred from Veronica, as well as for D. derwentiana (including five subspecies). The chromosome number $n=21$ is reported for Parahebe lithophila and $n=20$ and 19 in Derwentia. The Tasmanian Veronica formosa is discussed and is considered to be allied to a group of taxa including Chionohebe.
\end{abstract}

\section{Introduction}

Parahebe W. Oliver was distinguished from Hebe Comm. ex Juss. by a combination of features (Oliver 1944) including chromosome numbers (Frankel \& Hair 1937, Frankel 1941), leaf serration, short corolla and laterally compressed capsule. Recent usage has included species of New Guinea (Royen \& Ehrendorfer 1970, Royen 1972) in addition to the New Zealand species (e.g. Ashwin 1961b, Moore 1967, Garnock-Jones \& Langer 1980, Chalk 1988). Three Australian species have been transferred to Parahebe from Veronica (Briggs \& Ehrendorfer 1968, 1986) and the combinations have been used in other publications (e.g. Burbidge \& Gray 1970, Jacobs \& Pickard 1981, Beadle et al. 1982, Beadle 1984, Barker 1986).

The genera have been regarded as poorly characterised but there has been agreement that Parahebe, Hebe, Chionohebe B. Briggs \& Ehrend. (formerly Pygmea J.D. Hook. non Pygmaea Stackh.) and Detzneria Schltr. ex Diels (the last mentioned by only some authors) form a southern-hemisphere assemblage distinct from Veronica (Frankel \& Hair 1937, Royen 1972, Briggs \& Ehrendorfer 1976, Ehrendorfer 1971).

Hong (1984), Garnock-Jones (1991 and pers. comm.) and the present authors have made cladistic analyses relevant to the Hebe group of genera. Hong made a wideranging study of the Veroniceae and concluded that Parahebe grouped with Hebe and Chionohebe and more distantly with Detzneria, and that this assemblage of genera has 'its own developmental history based on a different geographical, morphological and chromosomal background from that of Veronica'. Garnock-Jones is investigating the whole assemblage but especially the numerous and diverse New Zealand members. We have found that relationships among the Australian taxa could not be studied satisfactorily without considering relationships among the major groups within Parahebe and Hebe and thus extending our study to the New Zealand groups. The results of our cladistic studies will be published elsewhere, depending on the outcome of other work. 
Grayer-Barkmeijer (1973, 1978 and unpublished, see Hong 1984) found that the Hebe group differed from Veronica, and from other Scrophulariaceae studied, in its iridoidphenolic acid metabolism. She also found differences in leaf flavonoids in different groups included in Parahebe sens. lat.

Parahebe (Oliver 1944) is predated by Derwentia Raf. (Rafinesque 1836), which was never taken into general use. Parahebe has been proposed for conservation against Derwentia (Garnock-Jones et al. 1990) so that a broad concept of Parahebe can, if appropriate, be retained without nomenclatural change. Such conservation does not prevent the adoption of Derwentia for a group of species that excludes the New Zealand $P$. catarractae (G. Forster) W. Oliver, type of Parahebe.

Originally it was our intention to transfer to Parahebe all the species that are revised in this paper, and herbarium annotations were made accordingly, using manuscript names under Parahebe. Further study, including more extensive consideration of species in New Zealand and New Guinea, as well as phylogenetic analysis, has convinced us that this is not appropriate. We conclude that only one Australian species should be placed in Parahebe ( $P$. lithophila) and that Derwentia can appropriately be adopted at generic level. But we exclude Veronica formosa R. Br. from Veronica, Parahebe and Derwentia and refer to it in discussion as 'Formosa' without generic assignment.

We refer in discussion and description of features to groups within Hebe and Parahebe and allies by names based for the New Zealand species on Moore (1961) and Ashwin $(1961 b, 1961 c)$ and as listed below. (A few of the following groups are not referred to in the present paper but are included to indicate the range of our cladistic analyses):

Parahebe sens. strict. (Ashwin's Parahebe group A, New Zealand)

Parahebe B (Ashwin's Parahebe group B, New Zealand)

'Lithophila' (Parahebe lithophila, Australia)

Parahebe New Guinean species

Derwentia (Australia)

'Formosa' (Australia)

Hebe sens. strict. (Moore's Hebe groups A-D, New Zealand, South America)

'Buxifoliatae' (Moore's Hebe group E, New Zealand)

'Flagriformes a' (Moore's Hebe 'Flagriformes' group a, New Zealand)

'Flagriformes b' (Moore's Hebe 'Flagriformes' group b, New Zealand)

'Flagriformes c' (Moore's Hebe 'Flagriformes' group c, New Zealand)

'Connatae' (Moore's Hebe group G, New Zealand)

'Paniculatae' (Moore's Hebe group H, New Zealand)

'Grandiflorae' (Moore's Hebe group I, New Zealand)

'Semiflagriformes' (Moore's Hebe group J, New Zealand)

Chionohebe (Australia and New Zealand)

Detzneria (New Guinea) 
The informal groups and placements of Moore and Ashwin are used here and listed above, although Heads (1987, but see also Garnock-Jones 1989) referred some of the species to his new genus Leonohebe Heads and formalised a number of sections within Leonohebe, some of them apparently based on Moore's informal sections or subsections.

Detzneria is sister group to the remainder of the Hebe group of genera in the preferred hypothesis arising from our cladistic studies. It has small trichomes near the leaf-base reminiscent of but smaller than those in the Chionohebe clade mentioned below. It shows a considerable number of striking autapomorphies in leaf shape and the large tubular flowers (unless the latter are plesiomorphic - many other Scrophulariaceae have large flowers). Its pollen, seeds and chromosome number $(n=24)$ are distinctive among the Hebe group of genera (Hong 1984).

\section{Chromosome numbers}

Parahebe was originally distinguished from Veronica partly on the basis of chromosome numbers. Base numbers of $x=20$ and $x=21$. have been recorded (Frankel \& Hair 1937, Frankel 1941, Hair 1967, Hair 1970, Moore \& Edgar 1970, Beuzenberg \& Hair 1983); both base numbers are found within Parahebe sens. strict.

The number $n=21$ is widely distributed; only Derwentia $(n=20,19)$, 'Hebe Flagriformes group a' $(n=20)$ and Detzneria $(n=24)$ do not, so far as known, include any species with $n=21$, while all species of Hebe sens. strict. reported have $n=20$ except $H$. verni$\cos a$ J.D. Hook. $(n=21)$. Reduction to $n=20$ has apparently occurred repeatedly: within Chionohebe, Parahebe sens. str. and, according to our phylogenetic analysis, at least twice in Hebe sens. lat.

Our findings and those of Frankel (pers. comm.) (Table 1, Figs. 1 and 2) show $n=21$ in $P$. lithophila and 'Veronica formosa'. The finding of $n=19$ in $D$. decorosa and D. arenaria brings a new number for the Hebe group of genera, but other Derwentia species counted (D. nivea, D. derwentiana, D. perfoliata) showed $n=20$. Chromosome number determinations by BGB were made on root tips using $p$-dichlorobenzene pre-treatment and alcoholic carmine stain, or on pollen mother cells.

The Hebe group is considered, by other authors and ourselves, to be palaeopolyploid, in contrast to Veronica which has base chromosome numbers of $x=7,8$ and 9 . The number $n=19$ indicates further dysploid reduction. Detzneria, reported to have $2 n=48$ (Borgmann 1964), may share with the Hebe group the synapomorphy of polyploidy, or its hexaploid level could possibly be derived separately, perhaps even from a different diploid base number. 
Table 1. Chromosome number determinations. Initials in the 'Det.' column refer to the determiner of the chromosome number record. BB, FE and OF refer respectively to Briggs, Ehrendorfer and Frankel. All vouchers in herb. NSW are also included with fuller information in the lists of specimens examined.

\begin{tabular}{|c|c|c|c|c|}
\hline Taxon & $n$ & $2 n$ & Det. & Source \& Voucher \\
\hline \multirow[t]{2}{*}{ Parahebe lithophila } & & 42 & BB & Mt Colong, Briggs 1125 (NSW) \\
\hline & & 42 & BB & Bulga Ridge, Rodd 517 (NSW) \\
\hline \multirow[t]{3}{*}{ 'Veronica formosa' } & 21 & & OF & $\begin{array}{l}\text { cult. Bot. Garden Christchurch } 1932, \\
\text { Frankel HV289 }\end{array}$ \\
\hline & & 42 & BB & $\begin{array}{l}\text { cult. Australian National Botanic Garden, } \\
\text { Canberra ex Freycinet Peninsula, Phillips }\end{array}$ \\
\hline & & 42 & $\mathrm{FE}$ & \\
\hline Derwentia nivea & & 40 & FE & \\
\hline D. decorosa & 19 & 38 & BB & Germein Gorge, Eichler 19209 (AD, NSW) \\
\hline D. arenaria & 19 & 38 & BB & $\begin{array}{l}\text { Blackmans Lookout, Warrumbungle Mtns, } \\
\text { Ehrendorfer, Briggs } 941 \text { \& Johnson (NSW) }\end{array}$ \\
\hline \multicolumn{5}{|l|}{ D. derwentiana } \\
\hline $\begin{array}{l}\text { subsp. not } \\
\text { termined }\end{array}$ & 20 & & OF & $\begin{array}{l}\text { cult. Bot. Garden Christchurch 1937, d e - } \\
\text { Frankel s.n. }\end{array}$ \\
\hline $\begin{array}{l}\text { subsp. not } \\
\text { determined }\end{array}$ & 20 & & OF & $\begin{array}{c}\text { Condor } C k \text { below Blundells plantation ACT, } \\
\text { Burbidge \& Frankel HV414, 5.2.55 }\end{array}$ \\
\hline subsp. homalodonta & & 40 & BB & Hindmarsh Tiers, MCArthur NSW 118325 \\
\hline $\begin{array}{l}\text { subsp.? (subsp. } \\
\text { homalodonta \& } \\
\text { anisodonta occur } \\
\text { in the vicinity) }\end{array}$ & c. 20 & & OF & $\begin{array}{l}\text { Flinders Chase, Kangaroo I., } \\
\text { Cleland HV415, } 15.12 .54\end{array}$ \\
\hline subsp. subglauca & & 40 & $\mathrm{BB}$ & Hampton, Briggs 1011 \& Johnson (NSW) \\
\hline \multirow[t]{5}{*}{ D. perfoliata } & 20 & & OF & $\begin{array}{l}\text { Cabramurra, Tumut R. Rd, } \\
\text { Frankel HV410 }\end{array}$ \\
\hline & 20 & & OF & Condor Ck, Burbidge \& Frankel HV415, 5.2.55 \\
\hline & & 40 & $\mathrm{FE}$ & Cherry Tree Hill, Ehrendorfer 8801 et al. \\
\hline & & 40 & BB & W of Tuross Falls, Johnson NSW 854491 \\
\hline & & 40 & BB & Granya Gap, Rodd 606 (NSW) \\
\hline
\end{tabular}




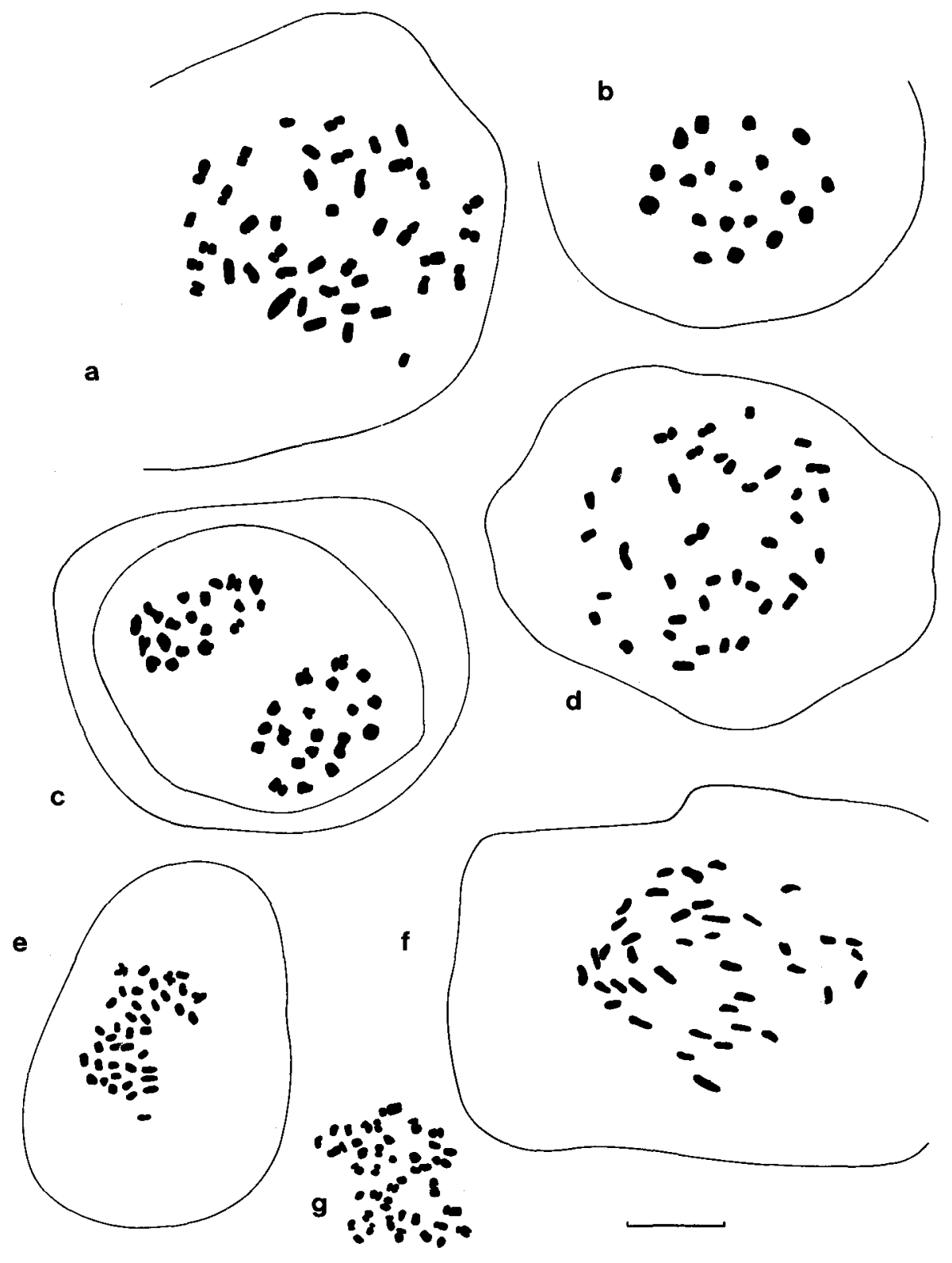

Figure 1. Chromosome complements. Counts from meiosis (1b, 1c) or root-tip mitosis. Vouchers are indicated in Table 1. a, Parahebe lithophila $2 n=42 ; \mathbf{b}$, Derwentia decorosa $n=19 ; \mathbf{c}, \mathbf{d}$ D. arenaria $n=19,2 n=38 ; \mathbf{e}, D$. derwentiana subsp. subglauca $2 n=40 ; \mathbf{f}$, D. velutina $2 n=40 ; \mathbf{g}$, D. perfoliata $2 n=40$. 


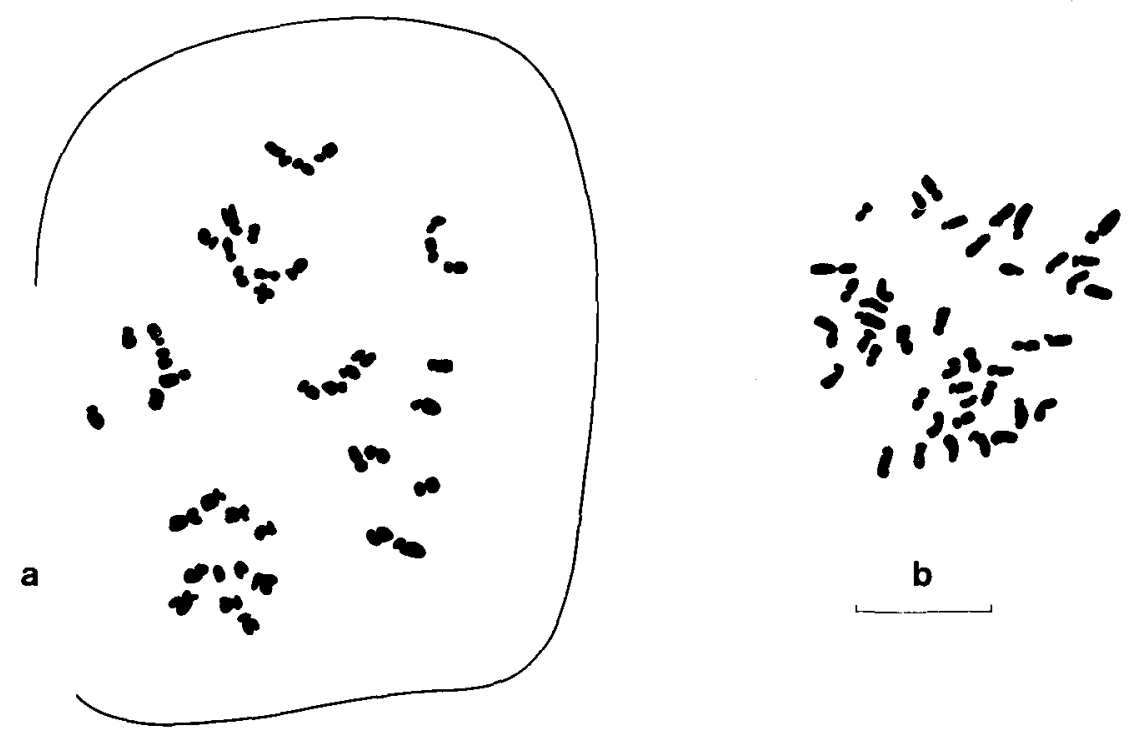

Figure 2. Chromosome complements. Counts from root-tip mitosis. Vouchers are indicated in Table 1. a, 'Veronica formosa' $2 n=42$; b. Chionohebe densifolia $2 n=42$.

\section{Notes on features of the taxa}

(Some comments extend beyond the species covered in this paper to give context of allied taxa.)

\subsection{Woody or shrubby habit}

This feature reflects the general rigidity and form of the plant and has involved somewhat arbitrary distinctions. 'Formosa', for example, has short-lived woody stems, whereas 'Parahebe B', 'Lithophila', Parahebe sens. strict. and Derwentia are softly woody or have woody bases. Many of the differences in habit depend on the extent of elongation and longevity of seasonal growth units (SGUs as in Briggs \& Johnson 1979 and equivalent here to repeating growth units of Grimes 1992). The habit is shrubby where SGUs are short but numerous and not regularly replaced by new growth, whereas Derwentia and possibly the New Guinean Parahebe species, and to a lesser extent 'Formosa', have elongated but little-branched and short-lived main stems.

Stems of all groups have a cylinder of secondary woody tissue even in soft, slender stems such as the erect stems of 'Lithophila' ( $<1 \mathrm{~mm}$ diam.) or the peduncles of racemes of $D$. derwentiana. Stems of Derwentia have a relatively thin xylem cylinder surrounding a broad pith whereas rigid woody stems, for example in Hebe propinqua (Cheesem.) Cockayne \& Allan (group 'Flagriformes a'), have a much narrower pith and thicker xylem. The xylem appears very similar in the species examined (only a small sample of the total species), having radial rows of small thick-walled cells with or without scattered larger vessels. Annual rings are usually visible in stems that have grown through several years. The species of Derwentia with longest-lived stems, $D$. velutina, showed up to four annual rings. Chionohebe species have a rather thick bark but the secondary xylem is poorly developed. 
Hong regarded a woody or shrubby habit as apomorphic within the Veroniceae but as a synapomorphy of the Hebe group of genera. Observations within this group of genera, and references such as Metcalfe \& Chalk (1950), suggest that woody Scrophulariaceae do not show highly unusual wood features, unlike several other families where woody members are considered to be derived from herbaceous ancestors, although Carlquist (1988) reports paedomorphic features in the wood of various Scrophulariaceae. The family is associated with others that are woody, such as Bignoniaceae and Myoporaceae, but is also close to largely herbaceous groups such as Acanthaceae, Selaginaceae and Lentibulariaceae (Thorne 1992, Dahlgren et al. 1981, Cronquist 1981, Dahlgren 1989). Most genera of Scrophulariaceae are herbaceous, and herbaceous tribes have generally been considered to be primitive within it (e.g. Thieret 1967), but there appears to be little evidence as to its plesiomorphic habit condition. Our cladistic analyses showed greater congruence and shorter trees when shrubby habit was treated as plesiomorphic and the non-woody taxa were scored for the apomorphy 'loss of shrub habit'.

\subsection{Trichomes}

The stout 2-4-celled trichomes ('cilia') on leaf margins in Chionohebe and 'Semiflagriformes' have a rough surface, sometimes with a spiral ornamentation of the cell walls, a feature shown by some trichomes of different morphology among these species and elsewhere in the Scrophulariaceae (Raman 1987). 'Formosa' and 'Parahebe $\mathrm{B}^{\prime}$ have these stout trichomes although they are of variable abundance and sometimes few in these taxa. Our attention was drawn to the significance of these trichomes, and to those in the corolla throat of Derwentia, by Dr Garnock-Jones (pers. comm.).

Short or very short glandular hairs with a 2-celled head are found in many species, and within Scrophulariaceae are not confined to the Veroniceae. Longer multicellular hairs occur on calyces of Chionohebe species; these have a single globular or pearshaped apical cell that generally collapses so that the apex is broad but concave and obconical. Similar hairs are seen, for example, in Hebe raoulii (J.D. Hook.) Cockayne \& Allan of the 'Paniculatae' and may be widespread. Other trichome types are present in some of the taxa and in particular locations, e.g. on calyx lobes and in the corolla throat of Derwentia, and warrant further study.

\subsection{Inflorescences}

The terminology and concepts of Briggs \& Johnson (1979), which include many of the definitions and terms of Troll (see Weberling 1981), assist in describing the inflorescences. As with other Scrophulariaceae, the basic unit-inflorescence (uniflorescence) is a raceme, generally anauxotelic. Some taxa show flexibility, with racemes either terminal or lateral or in both positions (Hamann 1960, Moore 1967). In other taxa, increasing fixity of structure appears to have restricted uniflorescences to either lateral (many taxa) or terminal positions. Veronica shows similar trends from a flexible condition (Hamann 1958).

Individual flowers in the racemes lack bracteoles (prophylls) but, where the uniflorescence is reduced to a solitary flower, a pair of 'bracteoles' (prophylls of the uniflorescence axis) generally remains and gives evidence that there has been reduction of axes. Phyllotaxy is spiral in the raceme, in contrast to the generally opposite phyllotaxy of vegetative parts. Sometimes, as in 'Formosa', the racemes are borne on an axis that may develop spiral phyllotaxy and is a short shoot with a bracteose, rather than a frondose, axis in the raceme-bearing region (a bracteose and often anauxotelic $R_{y}$ axis supporting bracteose $R_{z}$ raceme axes). Racemes in Derwentia are exclusively lateral except rarely on leafy lateral stems; the illustration in Barker (1986: 1301) 
depicts terminal as well as lateral inflorescences, rather than the characteristic condition for the species illustrated, namely $D$. decorosa and $D$. derwentiana.

The branching inflorescence of 'Paniculatae' apparently represents the reduction of a branching system of stem axes, hence the inflorescence 'peduncle' cannot be equated with that of a simple raceme as in Derwentia or Parahebe. Although the peduncles are bracteose and differentiated from the leafy parts of the plant in each case, those of the 'Paniculatae' are higher order axes $\left(\mathrm{R}_{\mathrm{y}}\right.$ not $\mathrm{R}_{\mathrm{z}}$ axes). The short leafy lateral branches of 'Formosa' appear homologous (in supporting lateral racemes) to the tall, erect, usually unbranched stems of Derwentia species such as $D$. derwentiana. The branched inflorescences of Hebe diosmifolia (A. Cunn.) Cockayne \& Allan may have also resulted from reduction of more extensive branching systems; it is the only instance of terminal racemes in Hebe sens. strict. which otherwise has racemes limited to lateral positions.

A contrasting interpretation of the limits of the inflorescence was put forward by Heads (1987). On the basis of differences between juvenile (or reversion-shoot) and adult foliage, he considered that, in most of the species of Hebe and Chionohebe with connate leaf bases, the adult leaves are derived from sterilised inflorescence bracts. As Garnock-Jones (1989) aptly states, this is a most novel interpretation of the evolutionary origin of the leaves, and no way is given to distinguish these supposedly bract-derived leaves from the true leaves of Hebe'.

Illustrations of New Guinean species referred to Parahebe (Royen \& Ehrendorfer 1970, Royen 1972) give the impression that the inflorescences mostly bear terminal flowers. Observation shows that the inflorescences are terminated by non-floral buds (blastotelic rather than anthotelic) conforming to the general inflorescence structures in this group of genera and in the Scrophulariaceae as a whole.

In part of Hebe sens. strict. small flower-size is associated with very numerous crowded flowers and the raceme may function as a single 'blossom' in attracting pollinators.

\subsection{Pollen}

Hong (1984) used six characters of the pollen grains in his cladistic analysis. He reported reticulate exine structure and a smooth colpus membrane in Detzneria but striate-reticulate exine and granular membrane in all samples of Hebe, Chionohebe or Parahebe [sens. lat.] studied.

Our SEM observations on the ten Australian species of these genera found all to have 'Veronica-type' pollen (Fig. 3). Thus they show colpate grains with striate-reticulate partial tectum, the colpus membrane is granular with fairly large irregular processes. As observed, the colpi range from wide (e.g. D. nivea) to narrow (e.g. P. lithophila, D. decorosa) but, since the grains were not acetolysed, these differences may reflect age of sample or be artifacts.

\subsection{Seeds}

The seed-coats of Derwentia species are ovoid, rugose abaxially but flattened adaxially. Those of 'Formosa' are circular, thin, smooth on both surfaces apart from a fine cell-pattern, concave adaxially and convex abaxially. Seeds of these groups lack the fine reticulate pattern of collapsed cells illustrated by Hong (1984) (and considered by him to be plesiomorphic in Veroniceae) and elsewhere in Scrophulariaceae by Sutton (1988), but that is only one of the ornamentation types in this diverse family (Corner 1976). 

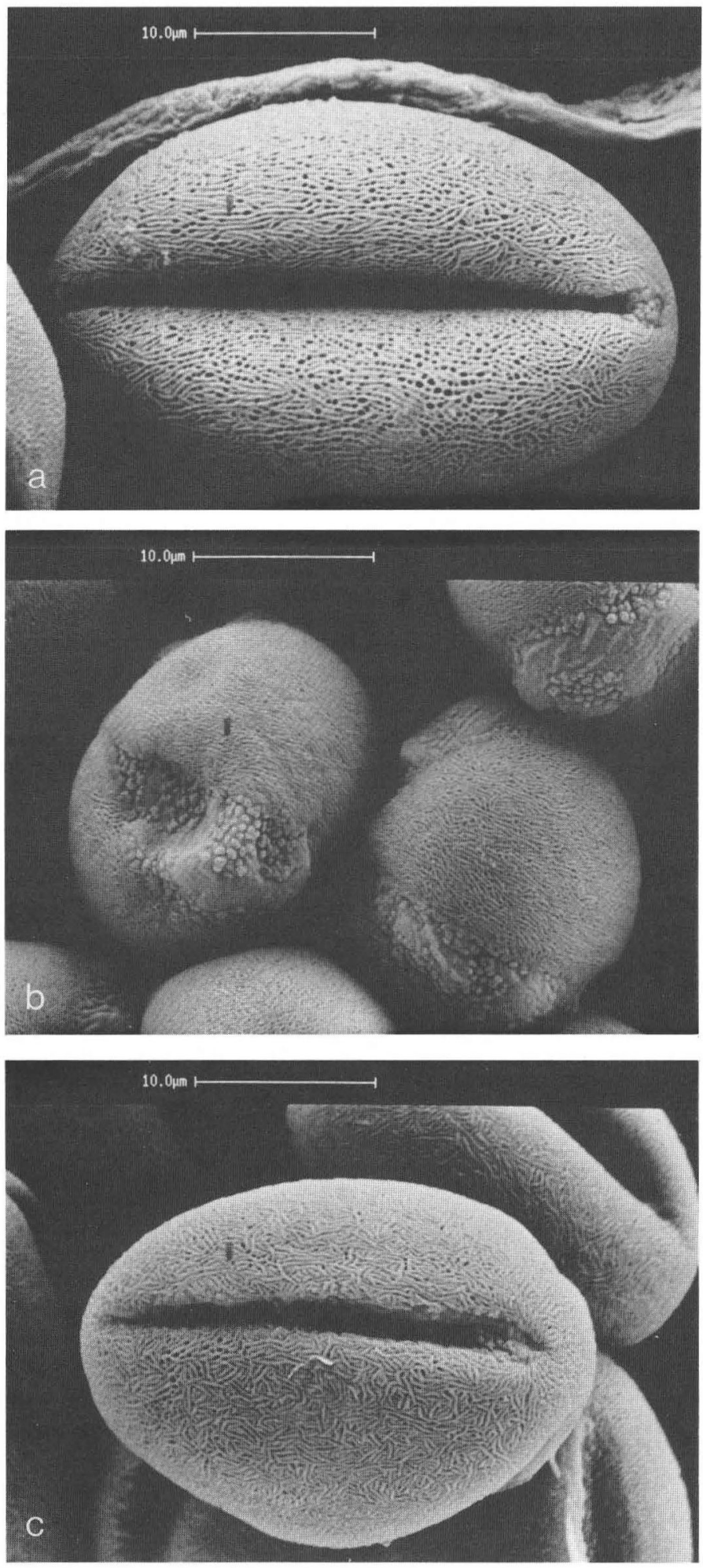

Figure 3. Pollen grains. a, Parahebe lithophila; b, Derwentia nivea; c, D. velutina. 


\section{The Veroniceae and phylogenetic studies}

Studies by Hong (1984) provide a context for investigations within the Veroniceae and suggest directions of character evolution. In his cladogram the Hebe group of genera appears to be relatively advanced within the tribe, although Detzneria retains plesiomorphic seed and pollen features that are shared with other Veroniceae. Some of these characters show much homoplasy, with granular pollen colpus membrane appearing four times in his cladogram. Largely because of these seed and pollen features, the first divergence that he shows among these genera is between Detzneria and a clade consisting of Chionohebe, Hebe and Parahebe.

Our cladistic studies used CLAX (Johnson \& Briggs 1984) and Hennig86 (Farris 1988). Because of extensive homoplasy and low levels of congruence among the relatively small number of characters (27), there were several competing equal-length minimal cladograms from CLAX and many from the Hennig analysis. The different results from these programs arise from their different treatment of character reversals. From them our preferred hypothesis is similarly that Detzneria is sister-group to the remainder, among which the analyses gave evidence of the four clades listed below.

(1) Parahebe clade (Derwentia, Parahebe - New Zealand, P. lithophila, 'Parahebe New Guinea');

(2) Hebe clade (Hebe sens. strict., Connatae, Buxifoliatae, 'Flagriformes');

(3) Chionohebe clade (Chionohebe, 'Semiflagriformes', 'Formosa', 'Parahebe B');

(4) 'Paniculatae'.

Hebe 'Grandiflorae' was variable in position and it associated in equal-length cladograms with any of the first three clades.

Dr Garnock-Jones (pers. comm.) was the first to point out the grouping Chionohebe 'Semiflagriformes' - 'Parahebe B' and also the very isolated position of 'Paniculatae', as found also in our study. We thank him for valuable unpublished information provided on various features used in the analysis.

Other workers have proposed alternative hypotheses which are at variance with our conclusions:

(i) In the course of a study of sexual conditions and floral form in Hebe and Chionohebe, Delph (1990) suggested that the 'Connatae' and 'Semiflagriformes' are phylogenetically close and that their common ancestor may have also given rise to Chionohebe. Our study does not support so close a link between 'Connatae' and Chionohebe.

(ii) Largely on the basis of an interpretation of leaf derivation and phyllotaxy, in an extremely brief treatment, Heads (1987) brought together 31 species under his new genus Leonohebe, typified by a species of the 'Semiflagriformes'. As well as separating the 'Semiflagriformes', 'Buxifoliatae', 'Connatae' and 'Flagriformes' from the remainder of Hebe, he divided Chionohebe. In the latter he retained the species with irregularly imbricate leaves but he transferred to Leonohebe two species with quadrifariously imbricate leaves (Ashwin 1961a). The quadrifariously imbricate condition is, of course, simply a condensation of the regularly decussate arrangement that is plesiomorphic for the whole group, whereas the irregularly imbricate arrangement is a modification of this condition. 
Garnock-Jones (1989) gave a valuable summary and assessment of the taxonomic changes made by Heads (1987); we agree with his strong doubt that Leonohebe, as circumscribed by Heads, is worthy of recognition. Our phylogenetic analysis placed components of Leonohebe in the Hebe and Chionohebe clades, each of which is marked by a considerable range of synapomorphies.

\section{Phytogeographic connections}

The Hebe group of genera, although restricted to the Southern Hemisphere, has an Australasian rather than Gondwanic distribution. It is absent from South Africa and the only representatives in South America are two or three species that occur also in New Zealand. These far-flung members give evidence of trans-oceanic dispersal, as do two species common to New Zealand and Australia.

Of the principal groups, the Parahebe clade includes members in Australia, New Zealand and New Guinea. The members of the Hebe and 'Paniculatae' clades are exclusively in the New Zealand region (from the Kermadecs to Chatham and Campbell Islands) except for the two species of Hebe sens. strict. found also in South America. Australia shares with New Zealand two species of Chionohebe; some limited distancedispersal of high altitude or temperate species is the simplest explanation of this. Questions remain as to the regions of initial diversification of this assemblage of genera and of the clades that span several land-masses. The only region where all the main clades (excluding Detzneria) are represented is New Zealand.

Detzneria occurs on the highest alpine peaks in Papua New Guinea. Since the New Guinea mountains did not reach such altitudes or such climatic zones until the Pleistocene (Ollier 1986), the ancestors of Detzneria may have existed in other regions.

Our phylogenetic conclusions imply the following dispersal or separation events for species of different land-masses. These events may have occurred at very different times and the directions of movement are not established:

\section{New Zealand-Australia}

- Separation of 'Formosa' from common ancestor with Chionohebe and allies.

- Separation of Derwentia or common ancestor of Derwentia and 'Parahebe New Guinea' from Parahebe sens. strict.

- Dispersal or separation of 'Lithophila' from the other species of its genus, i.e. Parahebe sens. strict.

- Dispersal of two species of Chionohebe, presumably from New Zealand to mountain or temperate regions of Australia (Briggs \& Ehrendorfer 1976).

\section{Other regions-New Guinea}

- Detzneria separated from the common ancestor of the other members of the Hebe group of genera.

- 'Parahebe New Guinea' separated from common ancestor with Derwentia, or common ancestor of Parahebe clade.

\section{New Zealand-South America}

- Dispersal of two species of Hebe sens. strict., presumably from New Zealand to South America. 


\section{Generic classification}

Decisions concerning the non-Australian taxa are best deferred until the cladistic analyses are published and studies by others are completed. The following decisions on generic levels are restricted to Australian taxa but have wider implications among these genera; they are adopted in Briggs \& Makinson (1992). It is relevant to note that many of our conclusions are also supported by the work of Dr Garnock-Jones, who will deal more comprehensively with these taxa in future publications, but that our conclusions diverge in some aspects.

\subsection{Parahebe}

Parahebe sens. lat., as recognised in the past, appears from our analyses to be a polyphyletic assemblage, defined by characters that are mostly plesiomorphic. The genus is therefore adopted in a narrow sense, with only one Australian species, $P$. lithophila, described below, included within it. In a study of breeding systems and floral morphology of New Zealand Parahebe, Garnock-Jones (1976) made clear both the diversity of groups that have been included within Parahebe and the important feature of folded lateral corolla lobes. He has also (Garnock-Jones 1991) observed that, in the Hebe group of genera, 'traditional use of both plesiomorphic and apomorphic character states has resulted in taxa that are paraphyletic' as well as others that are polyphyletic.

P. lithophila shares with Parahebe sens. strict. a generally similar corolla shape marked by 'honey guides'. The lateral corolla lobes show longitudinal folds in the newly open flower as in the New Zealand species, and the stamens spread close to the lateral corolla lobes in a generally similar way. The decumbent scrambling habit, leaf form, inflorescence and capsules are shared with New Zealand species but these features may be largely plesiomorphic. Grayer-Barkmeijer (1978) noted the presence of an unusual flavonoid-like compound in Parahebe sens. strict. but no information on chemical constituents is available for P. lithophila.

\subsection{Derwentia}

This group is accorded generic rank. There could be a case for adopting Parahebe sens. lat. to include Derwentia and the New Guinean species, since these appear to form a clade, albeit poorly characterised. Derwentia is, however, marked by a number of characters that are considered to be distinctive: the acutely toothed (rather than crenate) leaves, numerous flowers on short pedicels, presence of hairs in the corolla tube, and reduced chromosome number $(n=20$ or $n=19)$. It also differs from Parahebe in its primarily septicidal capsule dehiscence, a feature it shares with the New Guinean species. Grayer-Barkmeijer (1978) noted that D. derwentiana and D. perfoliata (which she reported under Parahebe sens. lat.) had similar flavonoid patterns but that there was 'no clear indication of any close relationships' with New Zealand species of Parahebe.

As a consequence of the recognition of Derwentia and narrow definition of Parahebe, it will presumably be necessary eventually to accord generic rank also to the New Guinean species, since they do not appear to be appropriately placed within Parahebe or Derwentia as now defined. The New Guinean species share a characteristic trichome type (brown hairs with frequent cell collapse).

The Derwentia species have a distinctive aspect and inflorescence form, but retain apparently plesiomorphic features such as the acute and scarcely compressed capsules of some species. Apparently apomorphic change to strongly compressed, emarginate capsules and dissected leaves has occurred within Derwentia, especially in D. nivea. 
Hebe species have toothed leaves in the juvenile stage (Garnock-Jones pers. comm.), and the deep lobing of juvenile leaves of $H$. cupressoides (J.D. Hook.) Cockayne (Cheeseman 1914: t.154) ('Flagriformes' group c), for example, is reminiscent of Derwentia nivea. It is possible that the condition in $D$. nivea, and perhaps the toothing of other Derwentia species, may be neotenous. Seedling leaves of $D$. derwentiana subsp. derwentiana have a few pairs of very shallow acute teeth. A population of $D$. perfoliata that has the adult leaves entire or with a few teeth showed similarly entire or shallowly toothed leaves at seedling stage. Thus, in the species for which we have information, Derwentia does not have markedly different adult and juvenile leaf forms.

\subsection{Veronica formosa $\mathrm{R}$. Br. and allied groups}

The taxon referred to above as 'Formosa' has generally been retained under Veronica in recent years (e.g. Curtis 1967: 522; Stones \& Curtis 1969: 98, t.52) although the combination Hebe formosa (R. Br.) Cockayne (Cockayne 1929: 434) has been made. It has been referred to informally as 'Parahebe formosa' (Hutchins 1990) and in the past we made herbarium determinations using this unpublished combination, which we no longer support.

The clade indicated by our analyses, that consists of this species together with the 'Semiflagriformes', Chionohebe and probably 'Parahebe B', has synapomorphies of entire and connate adult leaves (rarely crenate lobing has been observed in Chionohebe densifolia (F. Muell.) B. Briggs \& Ehrend. and toothing of leaves on lower branches of 'Formosa'), also the inflorescence is exclusively lateral and reduced to short racemes or single flowers.

Since other Australian members of the Hebe group of genera are now being removed from Veronica, retention of 'Formosa' under that generic name gives a misleading indication of its relationships. It appears unlikely that it will be appropriate to regard it as congeneric with any other member of its clade; we therefore intend to address its generic position in a forthcoming paper.

\subsection{Key to genera of the Hebe group in Australia}

1 Leaves toothed or crenate with leaf bases separate and leaf margins without stout trichomes or if leaves entire and connate (some individuals of Derwentia perfoliata) then leaf margins glabrous.

2 Corolla throat glabrous or with sparse short hairs, lateral corolla lobes longitudinally folded around stamens in newly-opened flowers, stamens spreading widely across lateral corolla lobes; capsule dehiscing primarily loculicidally or both loculicidally and septicidally; seeds broad-ovate or circular, flat and smooth on both surfaces; racemes with 1-18 flowers

Parahebe

2* Top of corolla throat with a ring of dense hairs, lateral corolla lobes not folded around stamens in newly opened flowers, stamens not spreading widely; capsule dehiscing primarily septicidally; seeds elliptic or ovate, flat adaxially but rounded and rugose abaxially; racemes with (4-)20-160 flowers

Derwentia

$1^{*}$ Leaves entire, leaf bases connate, leaf margins with stout white trichomes near the leaf base. [Corolla throat glabrous.]

3 Flowers in racemes of 2-25 flowers, 4-merous, bracteoles absent; shrubs $>0.5 \mathrm{~m}$ tall; leaves not imbricate, $5-21 \mathrm{~mm}$ long; capsule dehiscing primarily septicidally

gen. nov. ('Formosa', Veronica formosa) 
$3^{*}$ Flowers solitary, 5-merous, bracteoles present; low or cushion-like shrubs to $0.3 \mathrm{~m}$ tall; leaves imbricate, $2.5-7 \mathrm{~mm}$ long; capsule dehiscing both loculicidally and septicidally into 4 valves

Chionohebe

\subsection{Notes on the systematic treatment}

Most of the following descriptions include two indices used to quantify aspects of leaf shape.

Leaf index is the ratio of lamina length to lamina breadth (breadth being measured between the base of sinuses rather than between the tips of leaf teeth). Dentation index is the ratio 'outer breadth'/'inner breadth' of lamina; that is, the ratio of lamina breadth measured between the tips of the leaf lobes or teeth/the breadth measured between the base of sinuses of the lobes or teeth.

All specimens cited have been seen by one or both authors except where stated.

Several species are of restricted distribution and endangered but most Derwentia species and Parahebe lithophila will colonise moderately disturbed sites. However it is unlikely that Chionohebe species - even though they occur in sparsely vegetated microhabitats - would be effective colonisers.

Conservation status is given for rare and restricted species with conservation status codes as in J. Briggs \& Leigh (1988).

\section{Parahebe Oliver}

Parahebe Oliver (1944: 229). TypE: Parahebe catarractae G. Forster (New Zealand).

Softly woody shrubs or herbaceous but with woody bases; stems arising from a woody rootstock or trailing, sometimes rooting at nodes, pilose, hairs often in bifarious bands. Leaves opposite, petiolate, \pm pilose; margins crenate-dentate without stout marginal trichomes. Inflorescences racemose, bracteose, borne laterally, with spiral phyllotaxy in the raceme; flowers several to many but not very numerous, wellspaced, pedicellate. Calyx deeply 4-lobed, often ciliolate but without stout marginal cilia. Corolla white, lavender or pinkish, shortly tubular with 4 widely spreading, unequal lobes, often with darker nerves ('honey-guides'), without hairs in the tube or throat; lateral lobes longitudinally folded around the stamens after anthesis; veins branching (with curving lateral branches) in the tube or at the base of the tube. Stamens 2, epipetalous, inserted in the corolla tube, the filaments spreading over the lateral corolla lobes. Ovules many, crowded on a convex placenta. Capsule laterally compressed, emarginate, dehiscing both loculicidally and septicidally or less deeply septicidally. Seeds usually many, flat, not reticulate. Chromosome number: $n=21$ or less often $n=20$.

SPECIES AND DISTRIBUtION: Several species in New Zealand and one in Australia. Other Australian species that have been referred to Parahebe are now excluded from the genus and the inclusion of New Guinean species and some New Zealand species is under review (Garnock-Jones pers. comm.) 


\section{Parahebe lithophila B. Briggs $\mathcal{E}$ Ehrend., sp. nov.}

Inter species Parahebes combinatione characterum sequentium distinguitur: laminae foliorum (5-)12-25 mm longae, (3.5-)8-15 $\mathrm{mm}$ latae, pagina abaxiale non pallida sed saepe laete purpurea; pedunculi nec dense glandularepilosi nec albopubescentes; corolla lavandulacea.

TYPE: New SOUTH WaLes: Central Tablelands: Bulga Range, c. 6 miles [10 km] NW of Yerranderie; map reference, Yerranderie sheet, approx. 145924; alt. $670 \mathrm{~m}, A$. Rodd 517, 17 Sep 1967; holo NSW; iso AD, CHR. The type collection is also the chromosome count voucher.

Softly woody herb. Stems ascending to $15(-30) \mathrm{cm}$ or prostrate and rooted at the nodes and to $0.5 \mathrm{~m}$ long, usually sparingly branched, longest internodes $1-3(-5) \mathrm{cm}$ long, terete, $0.5-2 \mathrm{~mm}$ diam., with short fine hairs evenly and densely distributed or in longitudinal bands; hairs rigid, antrorsely curved, $0.2-0.6 \mathrm{~mm}$ long. Leaves spreading, petiolate; petiole $2-7.5 \mathrm{~mm}$ long, $0.2-0.8 \mathrm{~mm}$ broad, lamina broad-ovate or lanceolate, (5-)12-25 mm long, (3.5-)8-15 mm broad, leaf index 1.2-1.6, with 2-9 slightly spreading shallow acute teeth on each side, dentation index 1.05-1.5, commonly bright purple below, flat except for the narrow revolute margin, with 3-5 nerves from near the base and usually 2 major nerves from the midrib, the nerves prominent on the lower surface, glabrous or with sparse short curved hairs abaxially on the midrib, the base truncate or subcordate, the apex acute. Racemes single or opposite at each of 1-2 upper nodes of stems or lateral on prostrate stems, the floriferous portion $2-9 \mathrm{~cm}$ long with (1-)3-10(-18) flowers; the peduncle (1-)2-5 cm long. Bracts narrow-ovate, subacute, (1-)2-5 mm long, (0.3-)0.6-1(-2.5) $\mathrm{mm}$ broad. Fruiting pedicels $7-22 \mathrm{~mm}$ long, the lower longer than the upper. Calyx lobes elliptic, obtuse to subacute, imbricate in bud, 2-4.5 mm long and $0.7-1.8 \mathrm{~mm}$ broad in fruit, glabrous or with very short sparse curved papillose hairs, the margins glabrous. Corolla lavender with darker nerves, 6$7 \mathrm{~mm}$ long; adaxial lobe more prominently nerved, very broad ovate, obtuse, $7-8 \mathrm{~mm}$ broad; abaxial lobe ovate, obtuse, $3-4.5 \mathrm{~mm}$ broad, lateral lobes folded longitudinally around the stamens in bud and at anthesis; the throat with sparse very short hairs. Stamen filaments white, 3.5-6 mm long; anthers cream, 1.2-2 mm long. Ovules many, crowded on a convex placenta. Capsules broad-obovate or broad-elliptic, glabrous, glossy, compressed, emarginate, (2.5-)3-5.5 mm long, about as broad as long, 1.2-1.8 mm thick; dehiscing by a septicidal split $1 / 3$ of the distance to the base and loculicidally along the upper margin, or rarely dehiscing loculicidally with or without later septicidal dehiscence, finally usually splitting to the base along both sutures; style glabrous, 5-9 mm long, often eventually deciduous. Seeds to 30(-40), broad ovate or circular, c. $1.3 \mathrm{~mm}$ long, $1 \mathrm{~mm}$ broad. Chromosome number (Fig. 1a): $n=21$. (Fig. 4a, 5, 6).

DisTRIBUTION AND HABITAT: Localised towards the south-east of the Central Tablelands of New South Wales. Rooted in shallow pockets of soil on flat or almost vertical rocks, mostly on south-facing slopes, with stems trailing over the rock surfaces. On exposures of coarse sandstone, conglomerate, and quartzite, surrounded by eucalypt forest on ridges in mountainous country, c. 650-870 $\mathrm{m}$ alt. (Fig. 10).

CONSERVATION STATUS: Rare and with restricted distribution, but occurring in Blue Mountains National Park, Code 2RC-, listed by Briggs \& Leigh (1988) as 'Parahebe sp. 1 (Blue Mountains)'.

The epithet is derived from Greek lithos, a stone, and phileo, to love, referring to the species' occurrence on rock exposures.

Beadle et al. (1982) refer to this species in the comment that an undescribed species occurs in 'the Mt Colong area'. It was referred to as 'Parahebe sp. $\mathrm{A}^{\prime}$ in Jacobs \& Pickard (1981). 

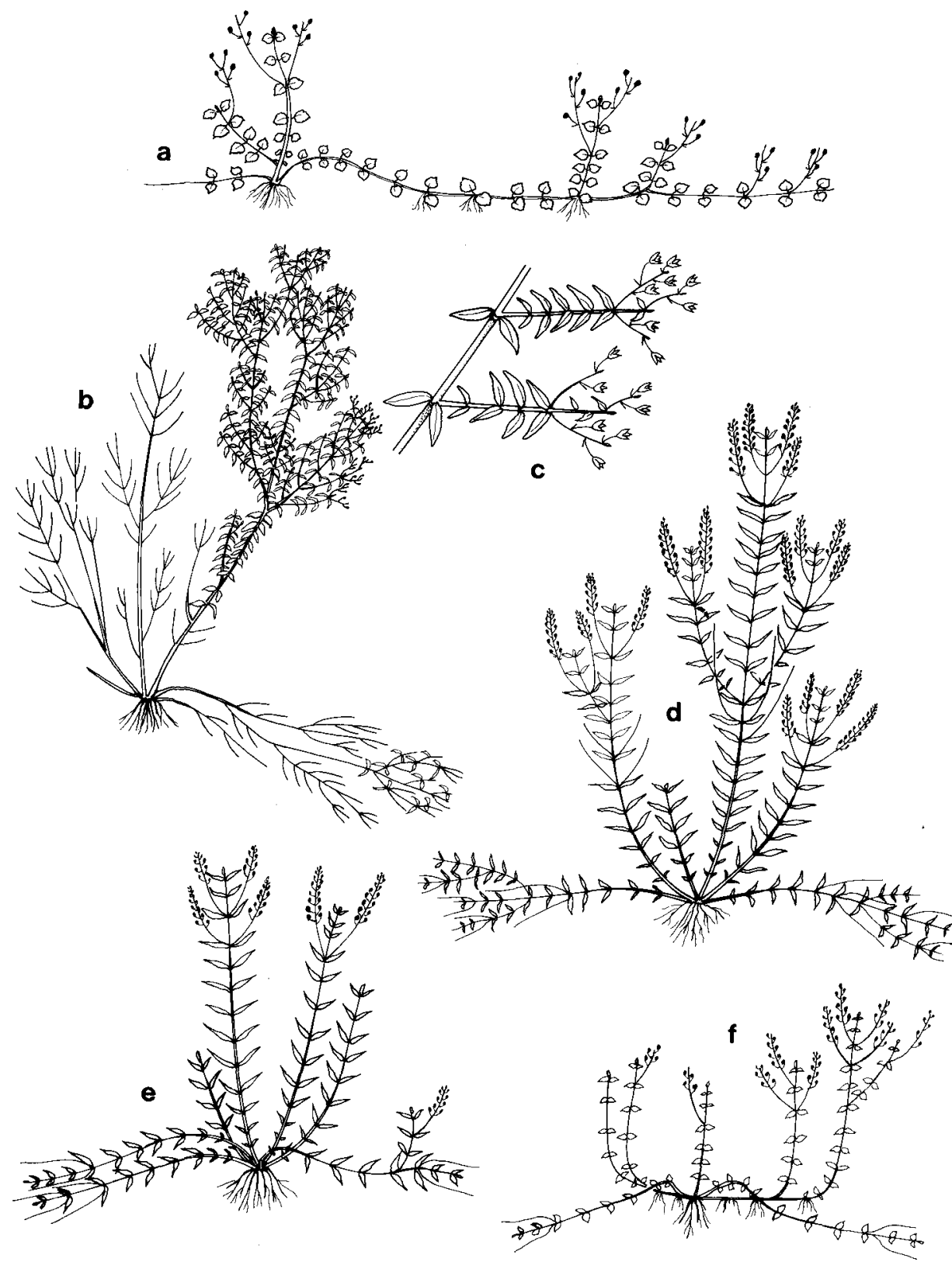

Figure 4. Habit types (diagrammatic). a, Parahebe lithophila: stems prostrate or ascending; inflorescences lateral on nodes of prostrate or erect stems; $b, c$, 'Veronica formosa': stems erect from a woody base, much branched, producing inflorescences over several seasons, finally becoming procumbent; (c) enlargement of inflorescence region; $\mathbf{d}, D$. decorosa, $D$. velutina: stems erect from a woody base, sparsely branched, producing inflorescences over several seasons before falling to ground, sometimes showing limited further growth after becoming procumbent; $\mathbf{e}, D$. nivea, $D$. arenaria, $D$. derwentiana, $D$. blakelyi: stems erect from a woody base, usually producing inflorescences in only one season, procumbent stems sometimes producing further terminal or lateral growth but rarely flowering again; $f, D$. perfoliata: similar to (e) but stems at first somewhat rhizomatous and plant forming a diffuse clump. D. arcuata may show type (e) or (f). 

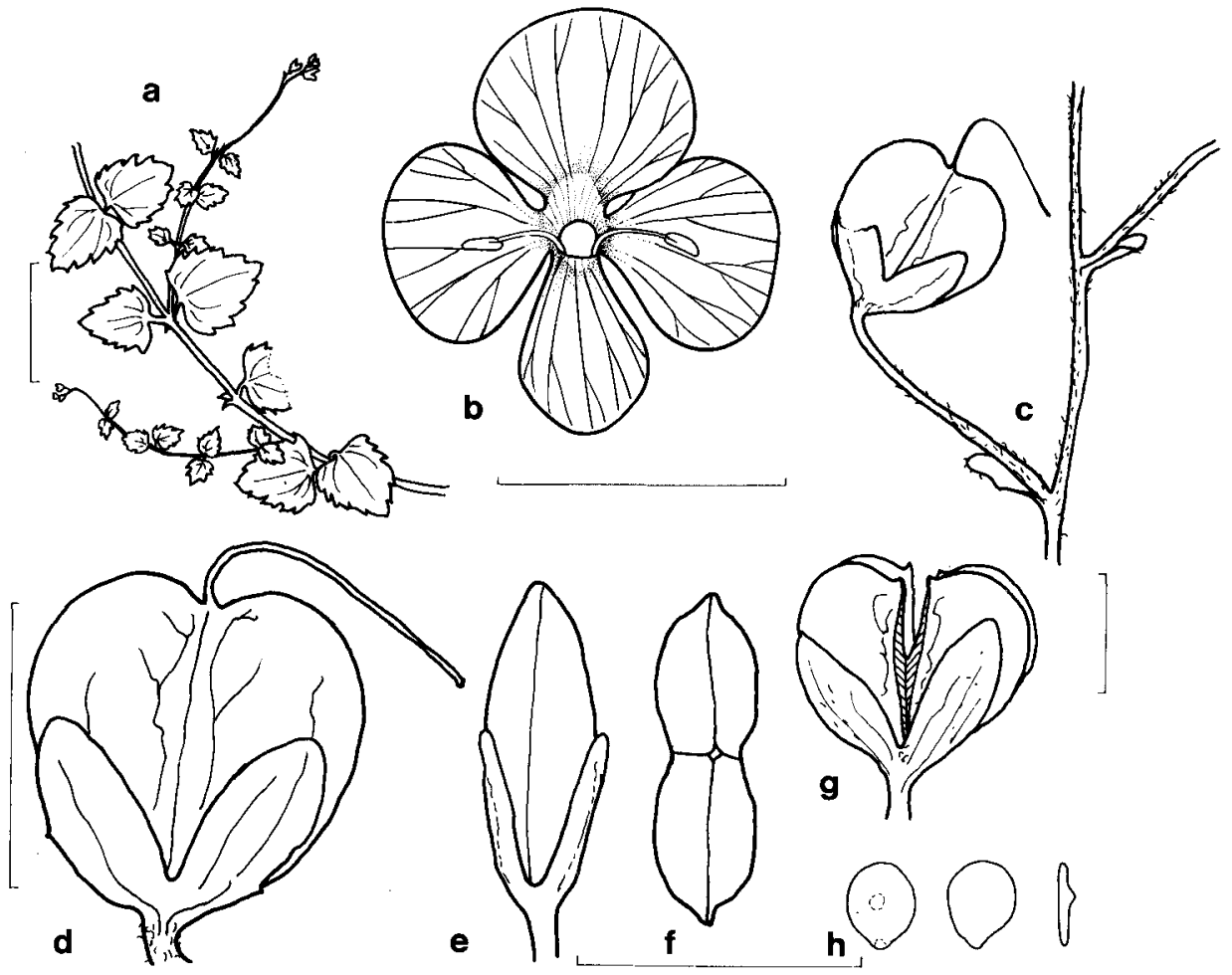

Figure 5. Parahebe lithophila. $\mathbf{a}$, leafy stem; $\mathbf{b}$, fully open corolla with stamens (cf. shape of corolla in recently opened flowers Fig. 6); c, portion of fruiting inflorescence; $d-f$, capsule with calyx lateral, abaxial and apical views; $\mathbf{g}$, dehisced capsule; $\mathbf{h}$, seeds - adaxial, abaxial and side views; $\mathrm{a}-\mathrm{f}$, h from Rodd 517 (holotype); $\mathrm{g}$, NSW 98190. Scale bars: $\mathrm{a}=2 \mathrm{~cm}, \mathrm{~b}=5 \mathrm{~mm}, \mathrm{c}=2 \mathrm{~mm}, \mathrm{~d}-\mathrm{f}=2.5$ $\mathrm{mm}, \mathrm{g}=2.5 \mathrm{~mm}$.

The species shows marked similarity to two New Zealand species, namely P. lyallii (J.D. Hook.) Oliver and the widespread and variable $P$. catarractae (Forst. f.) Oliver (Garnock-Jones \& Langer 1980). It resembles these in prostrate or decumbent habit, petiolate leaves of generally similar shape and dentation, mostly glabrous but the petioles hairy above; long-peduncled racemes; long pedicels; corollas of generally similar form, deeply cut into broad and obtuse lobes and with similar longitudinal folds around the stamens. Differences from the New Zealand species include fine curved rigid hairs on stems and peduncles, glabrous calyx margins, and frequently purple abaxial leaf surfaces.

Selected specimens: New South Wales: Central Tablelands: McMahons Lookout, Kings Tableland, A. Fairley $\mathcal{E}$ R. Miller, 2 Sep 1984 (NSW 166368); $1 \mathrm{~km}$ on track below McMahons Lookout, c. $20 \mathrm{~km}$ S of Wentworth Falls, B. Briggs 8958, 2 May 1992 (NSW, CHR); Kalang Falls, Kanangra Walls, A. Fairley, 15 Dec 1985 (NSW 156174); Coxs R., Blue Mtns, Willows, 6 Oct 1950 (NSW 13581); New South Wales, [Barrallier per?] Caley, 1799-1810 (BM, NSW); eastern spur of Mt Colong, Garden, 1 Oct 1951 (NSW 17266); Mt Colong, 1 km NE of summit, Briggs 1125, Rodd, \& Johnson, 23 Feb 1967 (NSW, AD, MEL), Briggs 1126 et al. (NSW, CANB, CHR, WELT), Briggs 1131 et al. (NSW, WU); Mt Colong, Carolin 5510, 23 May 1967 (SYD, NSW).

There are also reliable but unvouchered records of $P$. lithophila from: 'Spur of Scotts Main Range above Kowmung River near Christies Creek junction'; 'Gangerang Range 
between Gabes Gap and Mt Cloudmaker'; and 'headwaters of Little River near E boundary of Jenolan State Forest' (photo Fig. 6 Rodd 1985; note in herb. NSW).

The specimens cited in BM and NSW bearing Caley's name lack a locality note such as usually accompanies his specimens. The BM sheet was annotated by Caley: 'I suspect this to be the Veronica which Mr Brown saw in looking over the specimens gathered by Mr Barralier [sic]'. In 1802 Barrallier traversed the region about $30 \mathrm{~km}$ west of Nattai Junction (i.e. from about 25 to $60 \mathrm{~km}$ west by south of Camden) and his route probably included the area of the Bulga Range.

\section{Derwentia Raf.}

Derwentia Rafinesque (1836: 55). TYPE SPECIES: D. derwentiana (Andrews) Briggs \& Ehrend. Lectotypified by Garnock-Jones et al. (1990: 537).

Semi-woody shrubs or herbs with woody bases. Stems usually sparsely branched, often short-lived and arising from a woody rootstock; glabrous or pilose. Leaves opposite, sessile or with short broad petioles, glabrous or pilose, margins toothed or entire or leaves pinnatisect, without stout marginal cilia. Inflorescences racemose, bracteose, borne laterally, with spiral phyllotaxy in the raceme; flowers numerous to very numerous, often crowded, shortly pedicellate. Calyx deeply 4-lobed, without stout marginal trichomes (cilia). Corolla white, lavender, deep blue or rarely pink, shortly tubular with spreading, somewhat unequal lobes; sometimes with darker nerves ('honey-guides'),

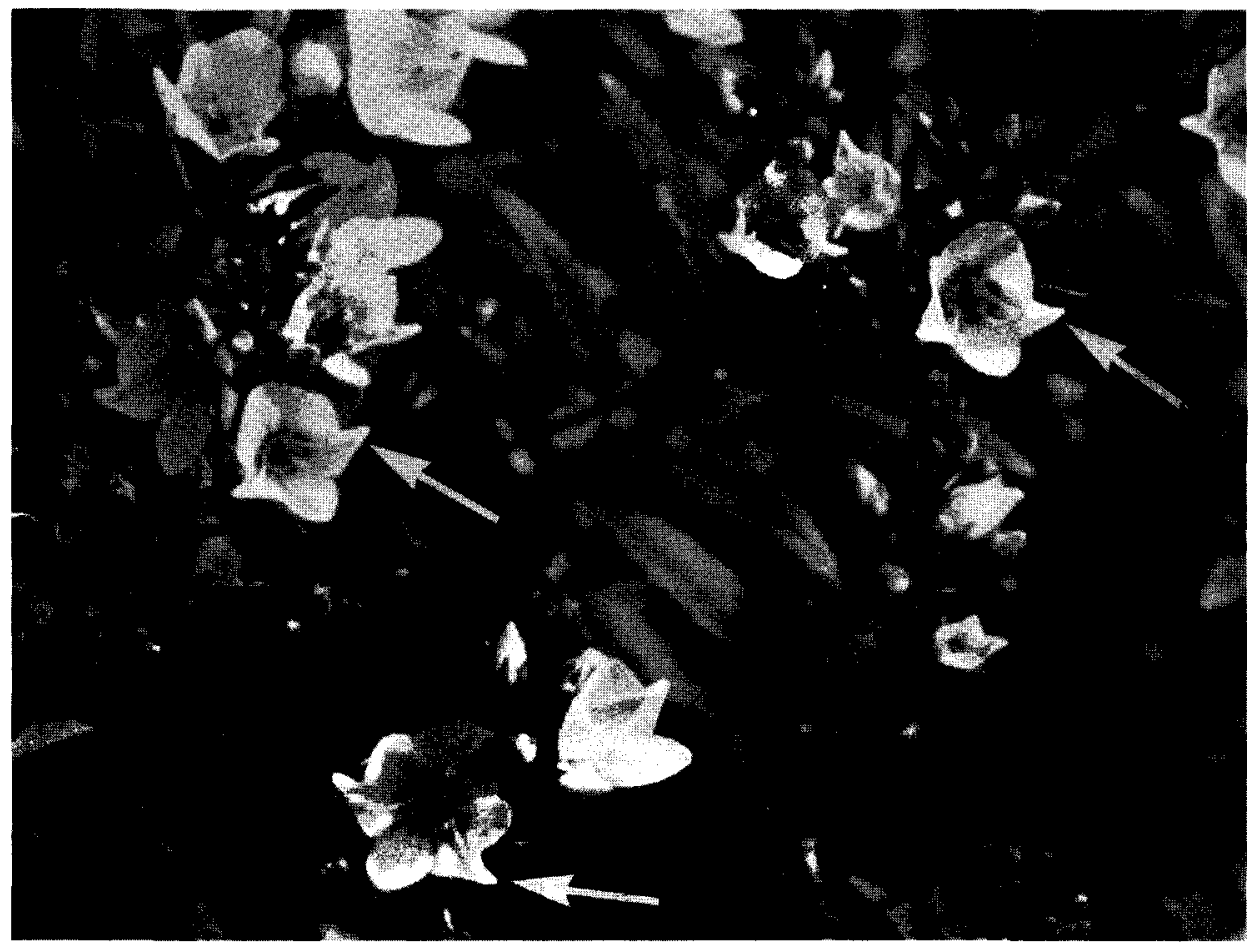

Figure 6. Parahebe lithophila showing corolla shape in newly opened flowers, at Little River, south-western Blue Mountains. Photo A.N. Rodd. 
lobes not folded longitudinally in the open flower but often \pm hooded toward apex; veins branching (with curving lateral branches) in the tube or at the base of the tube; the corolla tube or throat with long thin-walled hairs. Stamens 2, epipetalous, inserted in the corolla tube, the filaments not very widely spreading. Ovules on a narrow vertical placenta, few (6-12) and in two rows or relatively numerous (to c. 40) and irregularly crowded or in 2-4 \pm irregular rows. Capsule slightly or markedly laterally compressed, acute or truncate or emarginate, dehiscing septicidally and often less deeply loculicidally. Seeds several or many, ovoid, flattened adaxially, rugose abaxially, not reticulate. Chromosome number: $n=20$ or 19 .

SPECIES AND DISTRIBUtION: Eight species, endemic in south-eastern Australia, from southeastern Queensland to Tasmania and west to Kangaroo Island in South Australia, mostly in tableland or cool temperate regions.

\section{Key to species}

1 Leaves linear or with linear lobes or divisions, not glaucous; capsules emarginate.

2 Leaves pinnately divided with the primary segments $c .1 / 3-1 / 2$ as long as the leaves and often further divided or lobed; usually with compact clusters of leaves on very short lateral shoots at the lower nodes; capsules strongly compressed [4-6.5 mm long, 3-5.5 $\mathrm{mm}$ broad, 1-1.5 $\mathrm{mm}$ thick] ...... 1. D. nivea

$2^{*}$ Leaves entire or with teeth or lobes less than $1 / 5$ as long as the leaf; not developing compact clusters of leaves; capsules compressed or scarcely compressed.

3 Corolla white with lilac nerves; most leaves entire; capsules scarcely compressed, 2.5-3.5 $\mathrm{mm}$ long, 2-3 $\mathrm{mm}$ broad, $1.5-2 \mathrm{~mm}$ thick

2. D. decorosa

$3^{*}$ Corolla bright violet-blue; lower leaves mostly toothed; capsules compressed, $3.5-6 \mathrm{~mm}$ long, $2.5-3.5 \mathrm{~mm}$ broad, c. $1.5 \mathrm{~mm}$ thick

3. D. arenaria

$1^{*}$ Leaves very narrow-ovate to broad-ovate, entire or toothed, green or glaucous; capsules acute or truncate or emarginate.

4 Vegetative parts not conspicuously glaucous, except sometimes the lower surface of leaves; stems with sparse or dense short hairs or glabrous; leaves with 15-80 teeth on each side.

5 Leaves glabrous except for sparse hairs on the margins; stems usually with denser hairs $0.2-1(-2) \mathrm{mm}$ long in longitudinal bands; corolla white or pale lilac or pale blue

4. D. derwentiana

5* Leaves and stems densely and evenly covered with very short $(0.1-0.3 \mathrm{~mm})$ hairs; corolla violet-blue or pale lavender

5. D. velutina

$4^{*}$ Vegetative parts glaucous and glabrous; leaves entire or with up to 22 teeth on each side.

6 Leaves mostly V-shaped in transverse section, recurved, toothed; capsules obtuse or truncate or emarginate; fruiting pedicels $2-6 \mathrm{~mm}$ long

7 Corolla 6-7 mm long; capsules slightly or distinctly emarginate, compressed, 4-6.5 mm long, 1-2 mm thick

6. D. blakelyi

$7^{*}$ Corolla 9.5-11 mm long; capsules obtuse or truncate, slightly compressed, (4.5)6-9.5 mm long, 2.2-2.8mm thick...................................... 7. D. arcuata

$6^{*}$ Leaves mostly flat and spreading, entire or toothed; capsules acute or obtuse [very slightly compressed, $4.5-8.5 \mathrm{mmm}$ thick]; fruiting pedicels

(3-)5-12 mm long

8. D. perfoliata 
1. Derwentia nivea (Lindley) B. Briggs \& Ehrend., comb. nov.

BAsIONYM: Veronica nivea Lindley, Edwards Bot. Reg. Misc. n.s. 2: 42 (1842), non J.D. Hook. (Hooker 1844).

Type: Tasmania: Van Diemen's Land, Gunn 269, 1835; holo Lindley Herb. CGE, not seen, photo NSW; iso K, photo 2635 CANB ( 3 specimens on left of sheet).

Softly woody shrub to $0.5 \mathrm{~m}$ tall. Stems single or several, herbaceous or \pm woody toward the base, erect or ascending, appearing unbranched but with short lateral branches at most nodes developing a compact cluster of several leaves or with the laterals elongated and sometimes themselves branched, usually each stem flowering in only one season before dying back to the base; old stems sometimes becoming decumbent and with ascending lateral shoots; the stem-bases forming a compact or \pm spreading sympodially branched stock; stems terete, 2-5.5 mm diam., longest internodes 2-7 cm long; hairs in longitudinal bands, often sparse, antrorsely curved or irregularly twisted, $0.3-0.5 \mathrm{~mm}$ long, the cells often collapsed when dry. Leaves sessile, $15-30(-40) \mathrm{mm}$ long, pinnately divided into linear segments, leaf index 12-30, dentation index 8-28, rachis $0.7-1.5(-2.5) \mathrm{mm}$ broad, with (1-)2-5(-8) segments on each side; longest primary divisions 3-20 mm long and often further divided or toothed; the ultimate segments 0.5-1.2 mm broad, subacute, erect or spreading, flat or grooved above when dry, inconspicuously veined, glabrous except for the ciliolate bases of the margins, the margins thickened. Racemes single or usually opposite at each of 1-5 uppermost nodes, the floriferous portion (1.5-)5-17 cm long with (8-)20-40(-65) flowers; peduncle (1-) $3-5 \mathrm{~cm}$ long. Bracts mostly linear or narrow-ovate, $2.5-5 \mathrm{~mm}$ long; lower bracts often larger and pinnately divided. Fruiting pedicels $4-8 \mathrm{~mm}$ long. Calyx lobes ovate or narrow-ovate, subacute, $2-5 \mathrm{~mm}$ long and 1-1.5 mm broad in fruit, glabrous or with sparse short hairs near the base. Corolla white or pale lilac or bright blue, 3.5-6 mm long; adaxial lobe obovate or broad-obovate, obtuse, $1.3-2.5 \mathrm{~mm}$ broad; abaxial lobe obovate or narrow-obovate, obtuse, $0.8-2.5 \mathrm{~mm}$ broad. Stamen filaments white or lilac, $2.5-3.5 \mathrm{~mm}$ long; anthers cream or lilac, $1-1.5 \mathrm{~mm}$ long. Ovules mostly in two rows on a narrow vertical placenta. Capsules broad-obovate, glabrous, glossy, strongly compressed, deeply emarginate, 4-6.5 mm long, almost as broad as long, 1-1.5 mm thick, dehiscing by a loculicidal split across the upper margin and sometimes a shallow septicidal split for $c .1 / 3$ of the distance to the base; persistent style $3-5 \mathrm{~mm}$ long, glabrous. Seeds $10-25$, c. $1.5 \mathrm{~mm}$ long, $0.8 \mathrm{~mm}$ broad. Chromosome number: $n=20$. (Fig. 4d, 7).

DisTRIBUTION AND HABITAT: Kosciusko region of south-eastern New South Wales (most collections at 1500-2000 m alt.), mountain areas of eastern Victoria (1300-1500 m), and in Tasmania above (610?-)1050 $\mathrm{m}$ alt. In alpine and subalpine grassland, heath and bogs, and in subalpine woodland. (Fig. 8).

This species was referred to as 'Parahebe sp. C' in Jacobs \& Pickard (1981).

Selected specimens: New South Wales: Southern Tablelands: near Guthega Reservoir, Gauba, 9 Apr 1957 (GAUBA); Perisher Gap, Burbidge 6237, 7 Jan 1959 (CANB); head of Spencers Ck, Johnson \& Constable, 19 Jan 1951 (NSW 18426); near Betts Camp, c. $10 \mathrm{~km}$ ENE of Mt Kosciusko, Eichler 13607, 3 Feb 1957 (AD). VICtoria: Snowfields: Mt Buffalo, Cambage 3732, 19 Jan 1913 (NSW 599); Falls Ck Ski Village, Bogong High Plains, Eichler 14673, 2 Feb 1958 (AD); Falls Ck, aqueduct above township, Forbes 1185, 5 Dec 1982 (MEL, CANB, HO, NSW); Mt Wellington, Mueller, Nov 1854 (MEL); Echo Flat, Lake Mtn, Muir 2063, 26 Feb 1961 (MEL), Carroll, 26 Feb 1964 (CBG); Baw Baw Mtns, Williamson, Jan 1905 (MEL). Tasmania: Central Highlands: Pine Lake, near Breona, Whaite 2703, 21 Jan 1963 (NSW). Ben Lomond: Mt Arthur, Ratkowsky 1021, 20 Dec 1973 (MO, NSW); Mt Barrow, Burbidge 3002, 9 Jan 1949 (CANB). South West: Mt Field East, Mueller, Jan 1869 (MEL); Mt Field Natl Park, Lake Dobson area, Eichler 16774, 24 Jan 1960 (AD); Mt Wellington, Gunn 269 p.p., 1 Mar 1839 (BM photo CANB); Maiden \& Cámbage, Jan 1902 (NSW 6000), Darbyshire 1058, 3 Jan 1963 (CANB); Hartz Mtns, Lucas, Jan 1901 (NSW 6001). 


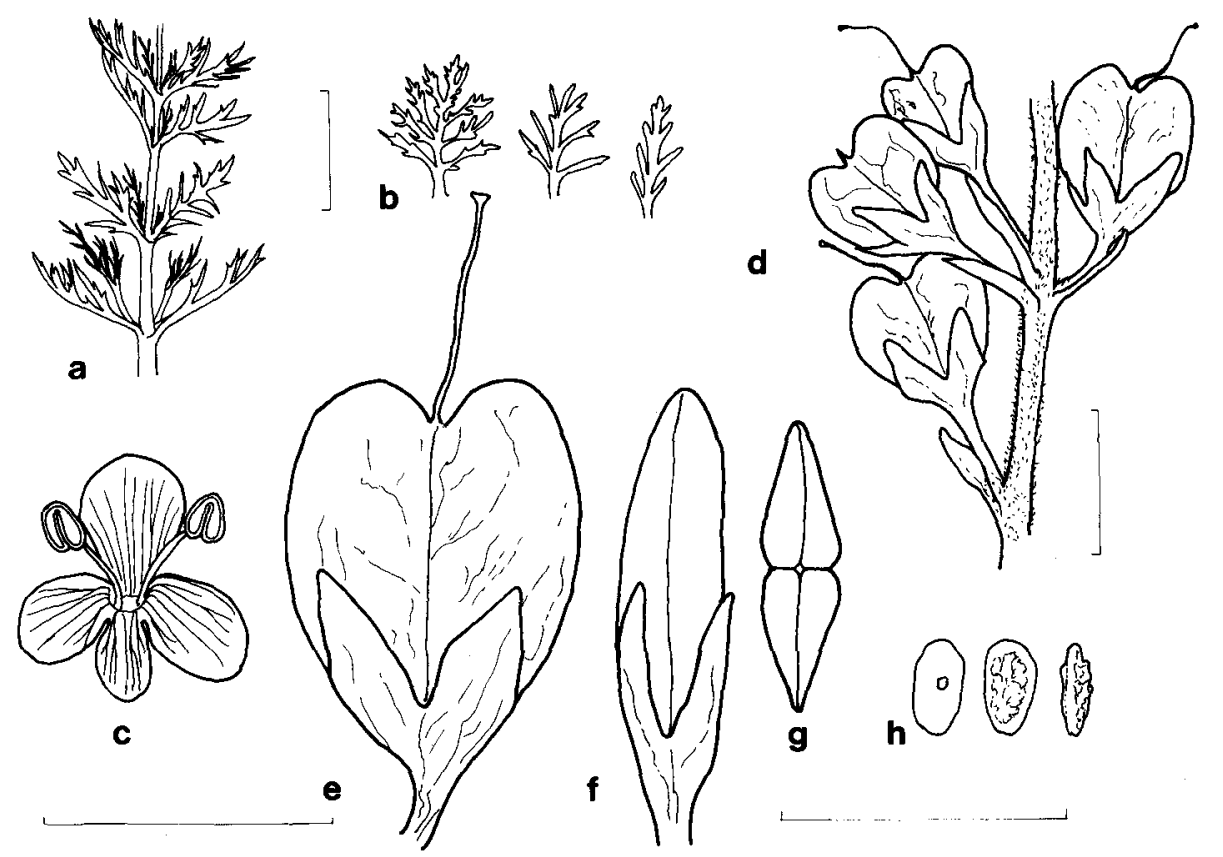

Figure 7. Derwentia nivea. a, leafy stem; b, leaves; $\mathbf{c}$, corolla with stamens; $\mathbf{d}$, part of fruiting inflorescence; $\mathbf{e}-\mathbf{g}$, capsule with calyx - lateral, abaxial and apical views; $\mathbf{g}$, dehisced capsule; $\mathbf{h}$, seeds - adaxial, abaxial and side views; a-d from Johnson NSW 84497; e-h GAUBA 9271. Scale bars: $\mathrm{a}-\mathrm{b}=2 \mathrm{~cm}, \mathrm{c}=5 \mathrm{~mm}, \mathrm{~d}=2 \mathrm{~mm}, \mathrm{e}-\mathrm{h}=2.5 \mathrm{~mm}$.

\section{Derwentia decorosa (F. Muell.) B. Briggs \& Ehrend., comb. nov.}

BasionyM: Veronica decorosa F. Mueller, Linnaea 25: 430 (1853).

Parahebe decorosa (F. Muell.) B. Briggs \& Ehrend. (1986: 1301), non P. decora Ashwin (1961b: 974, 877).

TYPE: SOUTH Australia: In vallibus saxosis montium Flinders ranges, [F. Mueller], Oct 1851; lecto MEL 21494 (here selected); iso K. Residual syntypes: Flinders-ranges prope M. [Mt] Remarkable, M. [Mt] Brown, F. Mueller, Oct 1851 (MEL 21495); interior of South Australia, Mueller, Oct 1851 (K, photo 2630 CANB).

Erect softly woody shrub $50-130 \mathrm{~cm}$. Stems much branched, continuing growth for several seasons; longest internodes $1.5-3 \mathrm{~cm}$ long, terete, 2-3(-5) $\mathrm{mm}$ diam., with short fine hairs in longitudinal bands or scattered; hairs rigid, antrorsely curved, 0.1$0.4 \mathrm{~mm}$ long. Leaves sessile, linear or subulate, acute, entire or the broader ones rarely with remote small teeth (teeth up to 7 on each side, spreading, to $1.5 \mathrm{~mm}$ long), (15-) $30-55(-70) \mathrm{mm}$ long, 1-2.5(-5.5) $\mathrm{mm}$ broad, leaf index 15-40, dentation index 1-1.4, grooved adaxially with a broad keel below, thickened and recurved at the margin, inconspicuously veined, glabrous or with very short glandular hairs along the adaxial groove. Racemes single or opposite at each of 1-5 of the upper nodes of one season's growth, the floriferous portion 10-18 cm long with (4-)10-45 flowers; peduncle 3-7 cm long; the inflorescence sometimes irregularly branched with lateral branches 


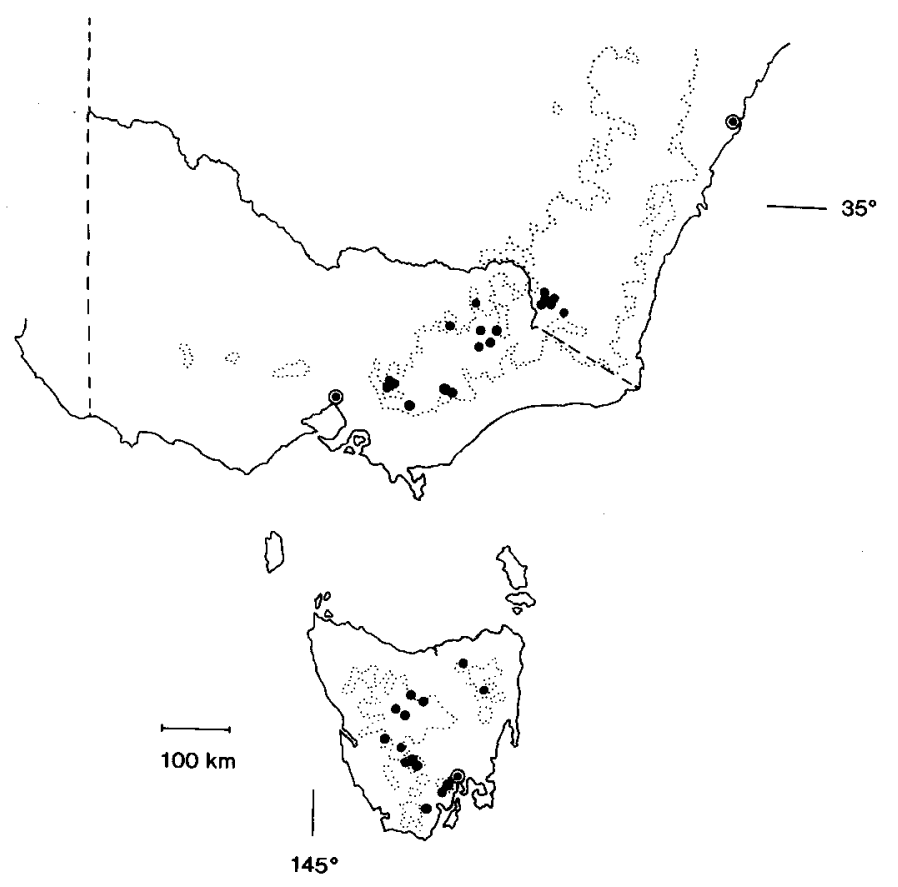

Figure 8. Distribution of D. nivea. The dotted line shows the $610 \mathrm{~m}$ (c. $2000 \mathrm{ft}$ ) contour.

bearing flowers and also further lateral inflorescences. Bracts linear to narrow-ovate, acute, 4-5 mm long. Fruiting pedicels 6-20 mm long. Calyx lobes narrow-ovate, acute, 4-8 $\mathrm{mm}$ long and c. $1.5 \mathrm{~mm}$ broad in fruit, glabrous or with a few short hairs at the base. Corolla white with lilac streaks, 4-10 mm long, hairy in the throat; adaxial lobe more prominently streaked, ovate to very broad-ovate, obtuse, $4.5-6 \mathrm{~mm}$ broad; abaxial lobe ovate or oblong, 2-4.5 mm broad. Stamen filaments white, 4-7 mm long; anthers $1-1.5 \mathrm{~mm}$ long. Ovules few in two rows on a narrow vertical placenta. Capsules glossy, broad-ellipsoidal or almost globular, shallowly emarginate, slightly compressed, 2.5$3.5 \mathrm{~mm}$ long, 2-3 mm broad, 1.5-2 $\mathrm{mm}$ thick, glabrous, dehiscing by a septicidal split which finally reaches the base and sometimes splitting loculicidally $2 / 3$ of the distance to the base; persistent style c. $5 \mathrm{~mm}$ long, glabrous. Seeds (mature) not seen. Chromosome number (Fig. 1b); $n=19$. (Fig. 4d, 9).

The epithet decorosa is derived from the Latin decorus, graceful, handsome and -osus having the quality of, full of. It thus includes an additional element not present in decora, the epithet of a New Zealand Parahebe species, and the two epithets are not to be treated as homonyms (L. Johnson pers. comm., advice on the conclusions of the Orthography Committee of International Association of Plant Taxonomists on similar cases).

Distribution AND habiTAT: South Australia, in the Flinders Ranges, and south to near the head of St Vincents Gulf, rocky sites, on ridges and more often in moist or sheltered sites within the generally arid region. (Fig. 10). 


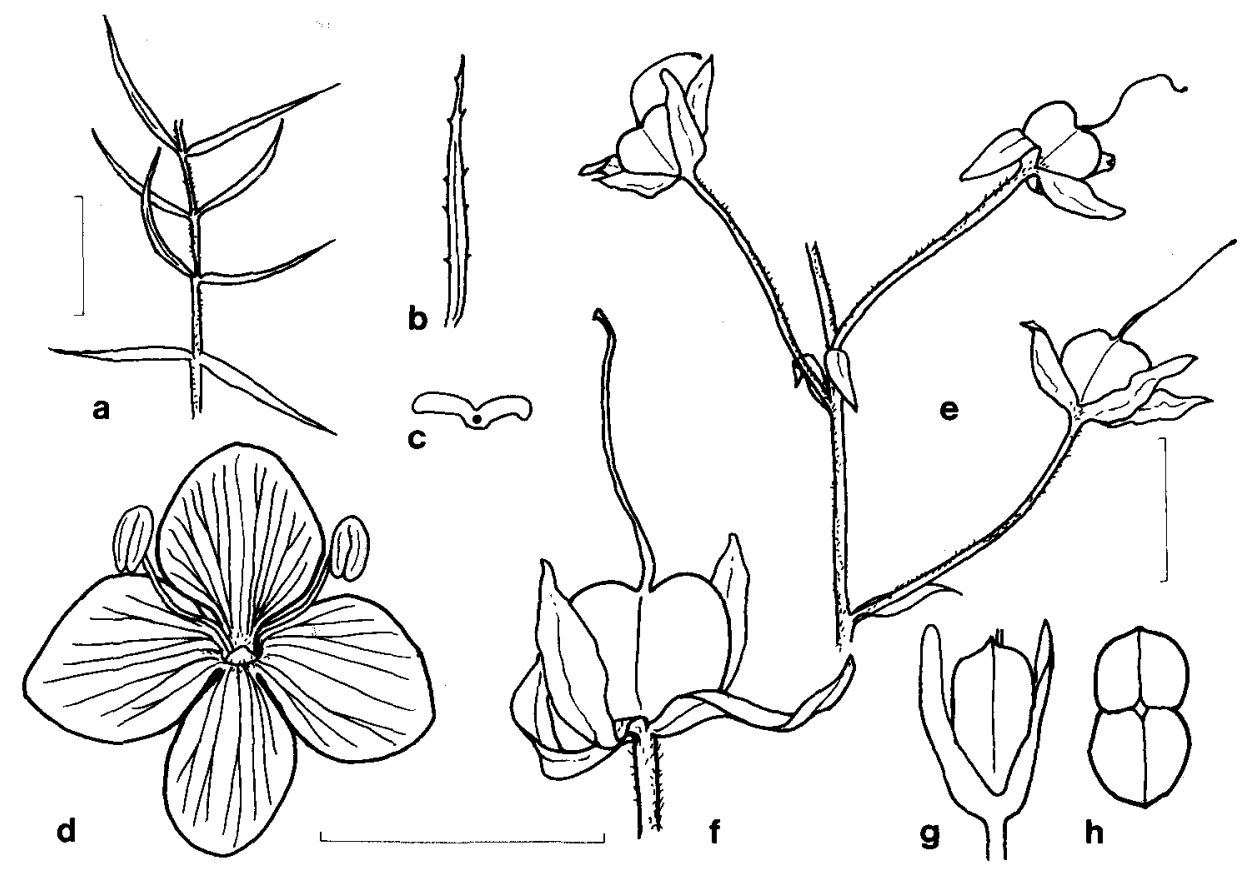

Figure 9. D. decorosa. $\mathbf{a}$, leafy stem; $\mathbf{b}$, leaf; $\mathbf{c}$, transverse section of leaf; $\mathbf{d}$, corolla with stamens; e, part of fruiting inflorescence; $f$, capsule with calyx - lateral, abaxial and apical views; $a, d-$ $\mathrm{f}$ Beauglehole 13453; $\mathrm{b}$ and c AD 96509254. Scale bars: $\mathrm{a}-\mathrm{b}=2 \mathrm{~cm}, \mathrm{c}=0.5 \mathrm{~mm}, \mathrm{~d}=5 \mathrm{~mm}, \mathrm{e}=2$ $\mathrm{mm}, \mathrm{f}-\mathrm{h}=2.5 \mathrm{~mm}$.

Selected SPECIMENS: South Australia: Eastern: Bibliando Stn $2 \mathrm{~km}$ from homestead in SW direction, T. Hall 136, 7 Oct 1984 (AD). Flinders Ranges: Mt Searle [Mt Serle, E of Leigh Ck], Warburton (K, photo CANB, MEL); Gammon Ranges, c. $65 \mathrm{~km}$ E of Leigh Ck, Eichler 1281, 19 Sep 1956 (AD); southern slopes of Yankininna Ra., Lothian 2095, 25 Aug 1956 (AD); Mt Hack, Lothian 5273, 19 Sep 1973 (AD); Arcoona Ck, L.D. Williams 11673, 31 Oct 1980 (AD, HO); Fergusons Gorge near Moolooloo, Ising, 9 Oct 1918 (AD); W of Pompeys Pillar at Wilpena Pound, Jackson 465, 7 Oct 1962 (AD); between Hawker and Moolooloo Stn, Carrodus, Sep 1956 (AD); Quorn, herb. Black, Oct 1924, 12 Oct 1926 (AD); $2 \mathrm{~km} \mathrm{SE} \mathrm{of} \mathrm{Mt} \mathrm{Brown,} 15 \mathrm{~km}$ NW of Wilmington, Sikkes 566, 20 Sep 1973 (CBG, AD, NSW); Mambray Ck, 3 miles [4.8 km] E of hwy, Beauglehole 13453, 28 Sep 1965 (NSW); Lower Mambray Ck, Symon 469, 11 Jun 1960 (AD); Germein Gorge, c. 8 miles from Port Germein, Eichler 19209, 29 Aug 1967 (AD, NSW); Jamestown, Francis (AD); Mt Bryan, Snell, Nov 1894 (AD); Worlds End, c. 30 km SE of Burra, Brummitt, 10 Nov 1892 (AD). 


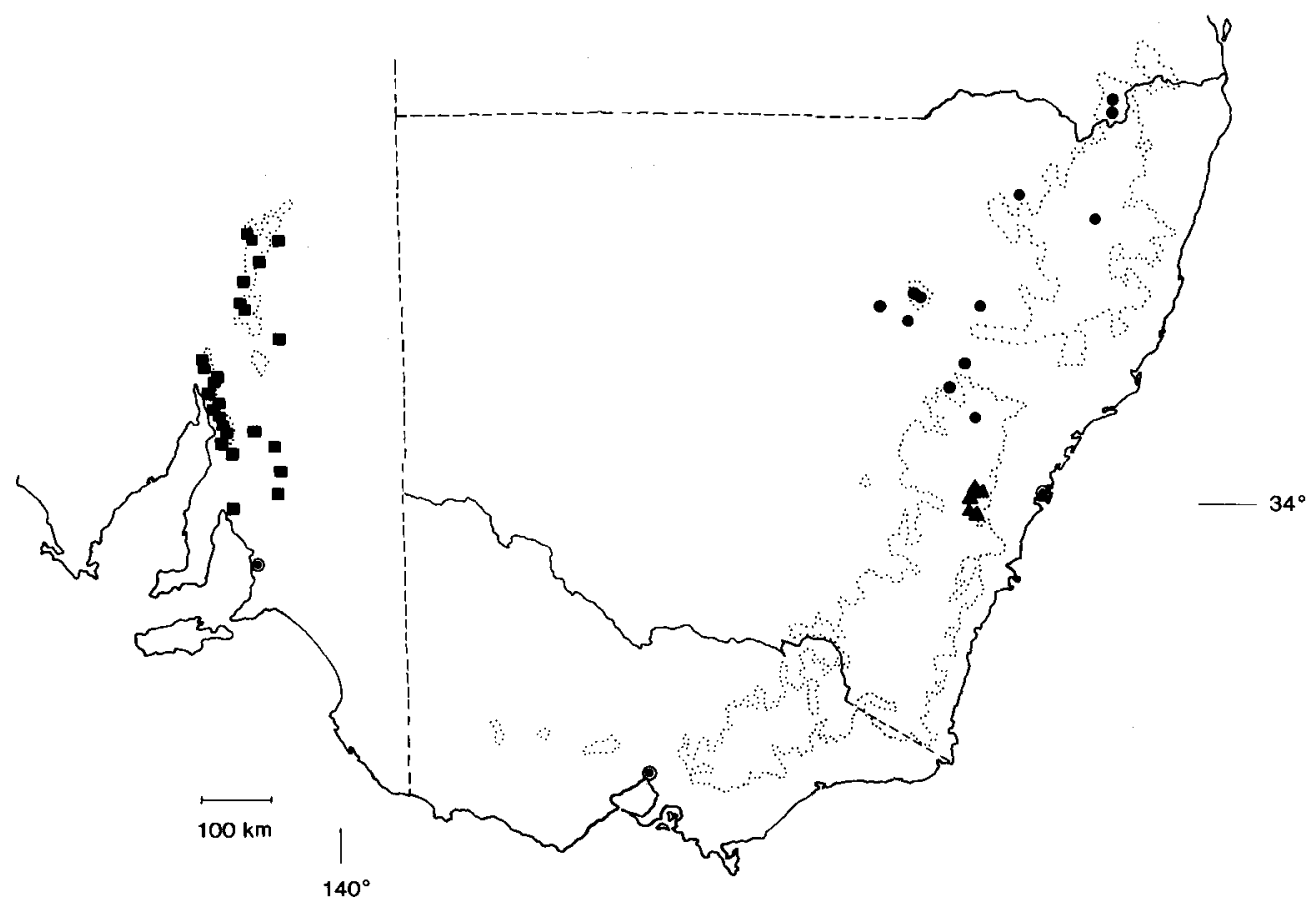

Figure 10. Distribution of Parahebe lithophila (ム), Derwentia decorosa $(\boldsymbol{\square})$ and D. arenaria $(\bullet)$. The dotted line shows the $610 \mathrm{~m}$ (c. $2000 \mathrm{ft}$ ) contour.

3 Derwentia arenaria (A. Cunn. ex Benth.) B. Briggs \& Ehrend., comb. nov.

BAsionym: Veronica arenaria A. Cunn. ex Bentham in Candolle, Prodr. 10: 463 (1846).

TyPE: New SOUTH WaLES: Central Western Slopes: arid sandy flat on the plain of Daby, Cugeegong [Cudgegong] River ... 50 miles [80 km] north from Bathurst, A. Cunningham, Apr 1823; holo K, 2 sheets, photos 2632, 2633 CANB; iso BM, MEL, NSW.

[V. dianthifolia A. Cunn. ex G. Don in Loudon (1830: 467), nom. nud. This and the following name are each accompanied only by horticultural comments which do not constitute a description.]

[V. pulchra G. Don in Loudon (1830: 7), nom. nud., invalid, published in synonymy. This name was altered to $V$. dianthifolia in the simultaneously published supplement.]

V. arenaria var. macrocalycina Moore \& Betche (1893: 340). TYPE: Upper Hunter River, L. Stephenson, Dec 1886; holo NSW 6090; iso MEL 21492.

Few-stemmed, slender, erect, softly woody shrub $0.3-1 \mathrm{~m}$ tall. Stems several from a narrow woody rootstock, sparingly branched, terete, 1-3 mm diam., the longest internodes $1-4 \mathrm{~cm}$ long, with short hairs mainly but not entirely confined to the longitudinal bands; the hairs rigid, antrorsely curved, $0.1-0.3 \mathrm{~mm}$ long; the primary stem soon ceasing growth and overtopped by laterals arising at the lower nodes, each stem usually growing for only one season before dying back almost to the base. Leaves sessile, linear and entire or with rather remote teeth or linear lobes, acute, $20-55 \mathrm{~mm}$ long, 1-3 mm broad (excluding lobes), leaf index 17-28; the teeth or lobes spreading, irregular in arrangement and size, up to 7 on each side, to $8 \mathrm{~mm}$ long and $1.3 \mathrm{~mm}$ 
broad, dentation index 1-15, tending to blacken when dry, only the midvein conspicuous, slightly thickened but not recurved at the margin, with short antrorsely-curved papillose hairs on the margin but otherwise usually glabrous. Racemes single or mostly opposite at 1-5 upper nodes, the floriferous portion (9-)20-35 cm long with (20-)50-100 flowers; peduncle 4-7.5 cm long. Bracts linear, acute, mostly 2-6 mm long, the lower ones to $14 \mathrm{~mm}$ long. Pedicels 4-7 mm long in fruit. Calyx lobes linear, acute, 4-10 $\mathrm{mm}$ long and 1-1.5 $\mathrm{mm}$ broad in fruit, shorter than or considerably exceeding the capsule, with sparse very short papillose hairs on the margins. Corolla bright violet-blue, the nerves not conspicuous when fresh, 7-10 mm long, the throat with dense hairs to $1 \mathrm{~mm}$ long; adaxial lobe ovate or broad-ovate, obtuse or acute, 3.5-5.5 $\mathrm{mm}$ broad; abaxial lobe narrow-ovate, acute, $1.5-3.5 \mathrm{~mm}$ broad. Stamen filaments dark blue, 6-7 mm long; anthers cream, 1-1.5 mm long. Ovules in 2-4 irregular rows on a narrow vertical placenta. Capsules slightly glossy, broad-obovate, compressed, emarginate, $3.5-6 \mathrm{~mm}$ long, $2.5-3.5 \mathrm{~mm}$ broad, c. $1.5 \mathrm{~mm}$ thick with short hairs on the upper margins, dehiscing septicidally and eventually splitting to the base on both sutures; style usually persistent, 6-12 mm long in fruit, pilose toward the base. Seeds c. 20 , c. $1.2 \mathrm{~mm}$ long and $0.7 \mathrm{~mm}$ broad. Chromosome number (Fig. 1c, 1d): $n=19$. (Fig. $4 \mathrm{e}, 11)$.

DisTRIBUTION AND HABITAT: The Stanthorpe district of south-eastern Queensland, and in New South Wales on the Northern Tablelands and from the Warrumbungles to the Cudgegong $\mathrm{R}$. in the North and Central Western Slopes. On rocky slopes to c. $870 \mathrm{~m}$ altitude and on river flats, in sandy soils, often in woodland. (Fig. 10).

CONSERVATION STATUS: D. arenaria is reasonably widespread and occurs in Warrumbungle National Park but is usually found only as scattered individuals. It would be coded 3RC.

This species was referred to as "Parahebe sp. B' in Jacobs \& Pickard (1981).

SeleCted SPECIMens: QueENSLAND: Darling, Downs: Wyberba, Blake 4659, 24 Jan 1933 (BRI, CANB); Stanthorpe district, Gittins, Feb 1948 (NSW 6092); Wallangarra, Boorman, Nov 1904 (NSW 6087), Jan 1906 (NSW 6091), Betche, Dec 1891 (NSW 6086). New SoutH Wales: Northern Tablelands: R. Ann [NE of Guyra], Beckler (MEL). North Western Slopes: Copeton Dam, 32 km NW of Bundarra, Wissman, 25 Aug 1976 (NSW 223489); Warrabah [Nature Reserve?], Namoi River, J. Coveny, Mar 1970 (NSW 223490); near Blackmans Lookout, N side of Belougery Split Rock, Warrumbungle Mtns, Ehrendorfer 9404, Briggs 941 \& Johnson, 24 Oct 1966 (NSW, WU); Belougery Split Rock, Warrumbungle Mountains, Briggs, 31 Jan 1961 (NSW 53766); Warrumbungle Natl Park, near junction of Burbie and Crooked Cks, Willis, 13 May 1969 (NSW 118256); Warrumbungle Mts, Godfrey, Mar 1970 (NSW 131641); Fans Horizon, Warrumbungle Ra., 28 km W of Coonabarabran, Streimann 498, 4 Dec 1973 (CBG, A, AD, BRI, K, NSW). Central Western Slopes: 'Wolaroi', Castlereagh R., c. $16 \mathrm{~km} \mathrm{~W}$ of Mendooran, Coveny 10420 E Benson, 16 Aug 1979 (NSW, AD, CANB, CHR, K, MEL); Dingo Ck, Goulburn R. Valley, Tame 1152, Nov 1984 (NSW).

\section{Derwentia derwentiana (Andrews) B. Briggs \& Ehrend., comb. nov.}

BAsionym: Veronica derwentiana Andrews, Bot. repos. t. 531 (1808). Originally published as $V$. derwentia, the corrected orthography was used in the 'Errata', published a few months later in 1808 with the index to Volume 8 of the Botanist's Repository. Being made by the author in such a manner, this change is to be accepted as a correction of an unintentional orthographic error under the International Code of Botanical Nomenclature. Brown (1810: 434) and Moore \& Betche (1893: 340) attributed the description of $V$. derwentia to Littlejohn but there is no reference to the latter author in the protologue. 

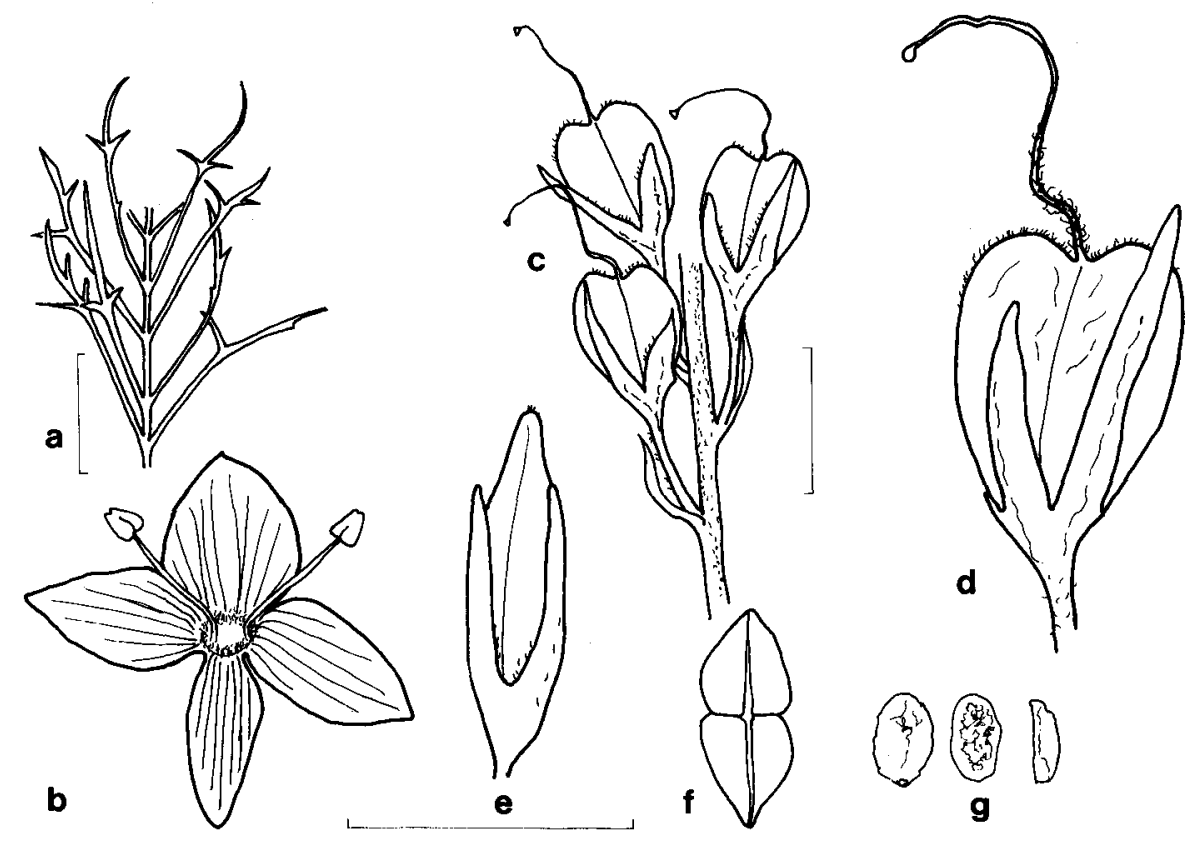

Figure 11. D. arenaria. $\mathbf{a}$, leafy stem; $\mathbf{b}$, corolla with stamens; $\mathbf{c}$, part of fruiting inflorescence; $\mathbf{d}-$ f, capsule with calyx - lateral, abaxial and apical views; g, seeds - adaxial, abaxial and side views; $\mathrm{a}$ and $\mathrm{b}$ from Ehrendorfer $\mathcal{E}$ Briggs 941; c-g Boorman NSW 6091. Scale bars: $\mathrm{a}=2 \mathrm{~cm}, \mathrm{~b}=$ $5 \mathrm{~mm}, \mathrm{c}=2 \mathrm{~mm}, \mathrm{~d}-\mathrm{g}=2.5 \mathrm{~mm}$.

TYPe: Tasmania: Plate 531 of Andrews (1808); "native of Botany Bay on the banks of the Derwent', 'sent over by one of the settlers' per A.B. Lambert, holo [the locality 'Botany Bay' is here used very loosely, to refer to the whole of south-eastern Australia].

$V$. labiata $\mathrm{R}$. Br. (Brown 1810: 434), nom. illegit. The earlier name $V$. derwentiana (as 'derwentia') is cited as a synonym.

Derwentia suaveolens Raf. (Rafinesque 1836: 55), nom. illegit.; based on Veronica derwentiana Andrews (cited by Rafinesque as Veronica derwentia Andrews).

Parahebe derwentiana (Andrews) B. Briggs \& Ehrend. (1968: 742).

Stems several or numerous from a large woody rootstock, mostly erect and unbranched below the inflorescence, at first herbaceous but becoming softly woody, (25-)50-140($200) \mathrm{cm}$ long, terete, $2-7(-10) \mathrm{mm}$ diam., the basal $2-15 \mathrm{~cm}$ usually \pm prostrate and with adventitious roots, the longest internodes $3-8(-11) \mathrm{cm}$ long, glabrous or with short fine hairs in longitudinal bands or rarely over the whole surface; hairs antrorsely curved or irregularly twisted, $0.2-1(-2) \mathrm{mm}$ long, the cells rigid or collapsing when dry; each stem growing for only one season but often persisting for a further season before the leaves and stem wither, the old stems often becoming \pm decumbent and sometimes producing erect lateral flowering shoots at their lower nodes or rarely with leafy lateral branches from near the base of the inflorescence. Leaves sessile or with short broad petioles, the laminae narrow-ovate to ovate, $(45-) 65-15(-240) \mathrm{mm}$ long, (7-)15-40(-50) mm broad, the base cuneate or truncate or cordate, the apex acute or acuminate, with (17-)30-80 apiculate teeth on each side (the teeth antrorsely 
directed or spreading or incurved at the tip, \pm uniform in spacing and depth or irregular), the upper surface dark green and slightly glossy, the lower surface paler and sometimes pruinose, with 5-7 nerves from near the base and 2-10 major nerves from the midrib, the margin thickened and often recurved, glabrous or rarely with sparse curved hairs on the margin. Racemes single or opposite at each of 2-8 of the uppermost nodes, the floriferous portion 8-25(-33) cm long, with (25-)40-100(-130) flowers, the peduncle $2-8(-13) \mathrm{cm}$ long. Bracts linear, acuminate, mostly $3.5-8 \mathrm{~mm}$ long; the lowermost larger, to $18 \mathrm{~mm}$ long. Fruiting pedicels $2-10 \mathrm{~mm}$ long. Calyx lobes elliptic or narrow-triangular, acute to acuminate, $2-5 \mathrm{~mm}$ long and $0.7-1 \mathrm{~mm}$ broad in fruit, glabrous or with scattered very short glandular hairs and sometimes a few short hairs at the bases of the lobes. Corolla white or pale lilac or pale blue, tinged with pink or lilac in bud, 5-9 mm long; adaxial lobe ovate or elliptic, obtuse to acuminate, $2.8-5.5 \mathrm{~mm}$ broad; abaxial lobe narrow-ovate or elliptic, usually acute, 1.4-2.8 mm broad. Stamen filaments usually white, $4.5-5.5 \mathrm{~mm}$ long; anthers pink or purple, $1.5-2 \mathrm{~mm}$ long. Ovules irregularly placed or in irregular rows on a narrow vertical placenta. Capsules slightly glossy, narrow- to broad-obovoid, \pm compressed, the apex acute or truncate or emarginate, $2.8-5.5 \mathrm{~mm}$ long, $2.5-4.5 \mathrm{~mm}$ broad, $1.3-2$ $\mathrm{mm}$ thick, glabrous or with short hairs on the upper margin and the base of the style, dehiscing by a septicidal split and eventually splitting to the base septicidally and for c. $1 / 2$ of the distance to the base loculicidally; style usually persistent, pilose toward the base or glabrous, 4-7 mm long. Seed 4-26, 0.7-1.5 mm long, 0.4-1 mm broad. (Figs. $4 \mathrm{e}, 12-15)$.

$D$. derwentiana is here divided into five subspecies, differing in geographic range. In one case (subsp. derwentiana intergrading with subsp. maideniana, see under the latter), plants with intermediate morphological features are common where the ranges of the subspecies adjoin. A probably hybrid with $D$. perfoliata, arising in cultivation, is mentioned under the latter species.

\section{Key to subspecies of $D$. derwentiana}

1 Summit of capsule subacute or truncate or rarely slightly emarginate; leaves paler on lower surface but not pruinose; base of style and summit of ovary pilose or glabrous.

2 Base of style and summit of capsule sparsely or densely pilose or rarely glabrous.

3 Leaves narrow- or very narrow-ovate, (7-)15-25(-35) $\mathrm{mm}$ broad, length (3-)4-11 times breadth, leaf base cuneate or truncate; pedicels (3.5-)5-7(-9) $\mathrm{mm}$ long in fruit ................................................ 4a subsp. derwentiana

$3^{*}$ Leaves ovate to narrow-ovate, $(20-) 30-40(-50) \mathrm{mm}$ broad, length $1.6-3.5$ $(-5.2)$ times breadth, leaf base cordate or less often truncate; pedicels 2-4 $(-5) \mathrm{mm}$ long in fruit

4 b subsp. maideniana

$2^{*}$ Base of style and summit of capsule glabrous or rarely with a few hairs.

4 Leaves ovate or narrow-ovate, $17-40 \mathrm{~mm}$ broad, length $2.5-3.5(-5)$ times breadth, serrate with uniform shallow antrorse or incurved teeth, leaf base cordate 4c subsp. homalodonta

$4^{*}$ Leaves very narrow-ovate, 14-28 mm broad, length 5-7 times breadth, serrate with deep irregular spreading teeth, leaf base abruptly cuneate 4d subsp. anisodonta

$1^{*}$ Capsule emarginate; leaves pruinose on lower surface (more noticeable in old leaves, this feature may be destroyed by heat-drying of specimens); base of style and summit of ovary glabrous 


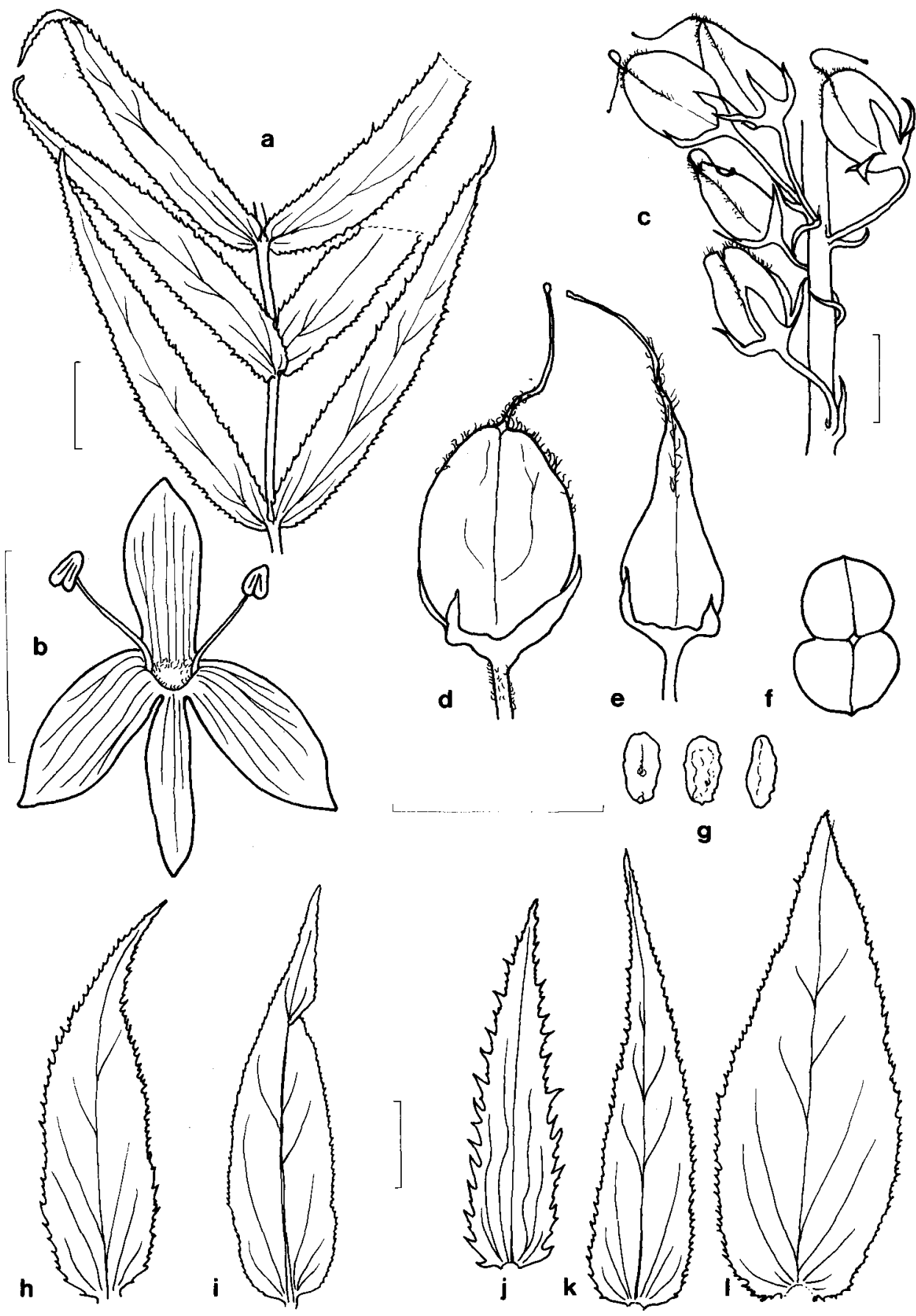

Figure 12. a-i, $D$. derwentiana subsp. derwentiana. a, leafy stem; $\mathbf{b}$, corolla with stamens; c, part of fruiting inflorescence; $\mathbf{d}-\mathbf{f}$, capsule with calyx - lateral, abaxial and apical views; $\mathbf{g}$, seeds adaxial, abaxial and side views; $\mathbf{h}-\mathbf{i}$, leaves: variation in two collections from Wandin, Victoria; a from Rodd 606a; b-g NSW 64434; h from Baker Dec 1906 (MEL); i sine coll., Feb 1905 (MEL). $\mathbf{j}-1, D$. derwentiana. Variation in leaves of different plants within a site in region of intergradation between subsp. derwentiana and subsp. maideniana; from Rodd NSW 101633-5. Scale bars: $\mathrm{a}, \mathrm{h}-\mathrm{l}=2 \mathrm{~cm}, \mathrm{~b}=5 \mathrm{~mm}, \mathrm{c}=2 \mathrm{~mm}, \mathrm{~d}-\mathrm{g}=2.5 \mathrm{~mm}$. 


\section{4a. Derwentia derwentiana subsp. derwentiana}

Leaves sessile; laminae narrow- or very narrow-ovate, the base cuneate or truncate, the apex acuminate, 80-150(-240) $\mathrm{mm}$ long, (7-)15-25(-35) $\mathrm{mm}$ broad, leaf index (3-)4-11; teeth \pm uniform in spacing and depth or irregular, antrorsely curved or spreading or incurved at the tip, dentation index 1.02-1.25, lower surface paler than the upper but not pruinose (but dried specimens sometimes with small scattered white patches on lower surface). Racemes: floriferous portion 9-20(-32) cm long. Pedicels (3.5-)5-7(-9) $\mathrm{mm}$ long in fruit. Capsules acute or truncate or rarely slightly emarginate, the summit and base of the style pilose with a sparse or dense indumentum of short hairs. Chromosome number: $n=20$. (Fig. 12).

Distribution AND HabiTat: South-eastern Queensland; New South Wales, on the South Coast, Northern Tablelands and Southern Tablelands; widespread in Victoria except for the north-west; in the extreme south-east of South Australia and in Tasmania. On a wide range of rock types including granite, basalt and shale, but neither this nor the other subspecies occur on soils of very low nutrient status. In moist situations in Eucalyptus forest, also on steep rocky slopes and alluvial river banks. (Fig. 13).

This taxon was referred to as ' $P$. derwentiana subsp. A' in Jacobs \& Pickard (1981).

This is by far the most widespread of the five subspecies of $D$. derwentiana and includes the greatest morphological diversity. It may represent the basic stock from which the other subspecies are relatively local developments.

In south-eastern Queensland and the Northern Tablelands of New South Wales it is the only subspecies present and extends from about $600 \mathrm{~m}$ to $1350 \mathrm{~m}$ altitude. It is absent from the Central Tablelands of N.S.W., where subsp. subglauca occurs in generally similar habitats. In southern N.S.W. and in Victoria it extends to low altitudes in coastal regions but does not occur in the drier inland districts. Some plants referred to subsp. derwentiana occur as high as $1300 \mathrm{~m}$, but above about $750 \mathrm{~m}$ alt. it is largely replaced by subsp. maideniana and plants morphologically intermediate between these two subspecies. In Tasmania it is the only subspecies represented and extends from low altitudes to very approximately $1000 \mathrm{~m}$ alt.

Occasional specimens are found at low altitudes with broad leaves resembling those of subsp. maideniana, but differing from the latter in other features, e.g. Frankston, Vic., Morrison, 21 Feb 1885 (CANB); Huon, Tas., Colbourn, 2 Jan 1926 (MEL 21573). In each case normal narrow-leaved plants are known from the same or nearby areas, e.g. Frankston, Morrison, 10 Jan 1892 (CANB, PERTH). There is great variation, often in a single locality, in the depth and regularity of the leaf serration (Fig. 12).

Plants with the ovary and style-base almost or completely glabrous are a rare occurrence at widely scattered localities, e.g. Nandewar Range, N.S.W., Schofield, 1 Mar 1965 (NSW 89388); Huon, Tasmania, Colbourn, 2 Jan 1926 (MEL 21573). These plants are not in areas where interbreeding with any of the regularly glabrous-styled subspecies is feasible.

Populations near the coast at Apollo Bay and from the Grampians in western Victoria to Mt Burr in eastern South Australia are very diverse and require further study. Some have very broad leaves and regular serration, e.g. Point Bunbury, Cowle (MEL); S side of Major Mitchell Plateau, Grampians, Beauglehole, 10 Dec 1967 (NSW 118317); while others have narrow leaves that are coarsely serrate, e.g. Grampians, Meebold 2150, 1 Jan 1929 (AD); Heywood, Renfrey, 3 Nov 1888 (MEL). Despite resemblances to other subspecies in particular features, these appear to be local developments from subsp. derwentiana, rather than being outliers from the range of any other taxon. The Heywood specimen mentioned has glabrous gynoecia but in western Victoria there is no 
general approach in this feature to the glabrous condition of the two localised South Australian subspecies.

Selected SPECIMENS: QueENSLAND: Darling Downs: $8 \mathrm{~km}$ SW of Cunninghams Gap, Pilkington, 5 Dec 1987 (BRI); Gladfield, Bailey, June 1892 (NSW 6167). New SOUTH WaLES: South Coast: Moruya, Boorman, Nov 1911 (NSW 6189); Mt Dromedary, Reader (MEL); Belowra, $40 \mathrm{~km} \mathrm{~W}$ of Narooma, Briggs 3095, 16 Dec 1969 (NSW, CBG, K, MO); Towamba, Eden district, McKee 6930, 3 Jan 1960 (CANB). Northern Tablelands: Southern end of Pheasant Mtn ... [29 km NE of Guyra], McGillivray \& Coveny 3612, 21 Apr 1971 (NSW, AD, CHR, K); c. $0.5 \mathrm{~km}$ W of Sinclair Peak, Nandewar Mtns, c. $1350 \mathrm{~m}$ alt., Johnson 7843, 1 Sep 1974 (NSW 222880); $1 / 2$ mile [0.8 km] E of Bakers Ck Falls, near Hillgrove, Williams, 11 Dec 1966 (NE); Barrington Tops, Althofer \& McReaddie, 8 Mar 1967 (NSW 95771). Southern Tablelands: Mt Majura (c. 4 miles [6.5 km] NNE of Canberra, ACT), Gauba, 1 Dec 1949 (GAUBA, CANB); Laurel Hill, [via] Tumbarumba, Cambage, 14 Mar 1903 (CANB); Brown Mtn near Bega, Constable, 25 Feb 1951 (NSW 15890); Wyndham to Cathcart, Gray 5681, 5683, 5685, 28 Jan 1965 (CANB, NSW). VICTORIA: Wannon: Lower Glenelg R., Eckert, 1891 (MEL). Grampians: Grampians, Sullivan (MEL 21605); along Forest Access Rd to Ararat near top William Ra., Whaite, 11 Nov 1953 (NSW 30068). Midlands: S side of Granya Gap, Murray Valley Hwy between Tallangatta and Jingellic, Rodd 606a, Apr 1968 (NSW). Volcanic Plains: $25 \mathrm{~km}$ NW of Portland on rd to Mt Deception, Briggs $5431 \mathcal{E}$ Beauglehole, 18 Feb 1975 (NSW, MEL). Otway Plain: Curdie R., Williamson, Dec 1899 (NSW 6180); Port Fairy, Whan (MEL). Victorian Highlands: Mountain Creek, Tawonga district, Rodd 381, 27 Dec 1966 (NSW); c. 5 miles [8 km] S of Harrietville on the Alpine Hwy, Craven 1554, 2 Feb 1969 (CANB, MEL, K, NSW); Ferntree Gully, Morrison, 5 Jan 1895 (AD). Gippsland Plain: Werribee, Fullager (MEL). Snowfields: south slopes of Mt Stirling, near Howqua Gap, Corrick 7971, 31 Jan 1982 (MEL, AD, NSW). East Gippsland: between Bemm and Coombinbah rivers, Sayer, 1887 (MEL). South Australia: South-eastern: Mt Burr, c. $35 \mathrm{~km}$ NW of Mt Gambier, Herb. Tate, Dec 1883 (AD). TASmania: Glen Leith, Gunn 2/1842, 2 Feb 1840 (NSW 6169); Mt Ben Nevis, Green (MEL); Cataract Gorge, Launceston, Johnson, 11 Jan 1949 (NSW 7299); Western Tier, 5 miles [8 km] from Poatina, Phillips, 6 Dec 1965 (CBG); Tunnel Hill, Ratkowsky 1055, 25 Dec 1973 (MO, NSW).

\section{4b. Derwentia derwentiana subsp. maideniana (Gand.) B. Briggs \& Ehrend., comb. et stat. nov.}

BAsIONYM: Veronica maideniana Gand., Bull. Soc. Bot. France 66: 220 (1919).

TYPE: New SOUtH WALES: Southern Tablelands: Mt Kosciusko, Maiden; holo LY, not seen; iso: Mt Kosciusko up to $5500 \mathrm{ft}$. [c. $1700 \mathrm{~m}$ ], J.H. Maiden, 1. 1898 (NSW 6201).

Leaves sessile; laminae ovate or narrow-ovate, the base truncate or usually cordate, the apex acute, (45-)7-100(-140) $\mathrm{mm}$ long, (20-)30-40(-50) $\mathrm{mm}$ broad, leaf index 1.6$3.5(-5.2)$; the teeth \pm uniform in spacing and depth or alternately large and small, antrorse or spreading, dentation index 1.02-1.17, the lower surface paler than the upper but not pruinose (dried specimens sometimes with small scattered whitish patches). Racemes: floriferous portion $8-17 \mathrm{~cm}$ long. Pedicels $2-4(-8) \mathrm{mm}$ long in fruit. Capsules as in subsp. derwentiana. (Fig. 14).

Distribution And habitat: Southern Tablelands of New South Wales and the Eastern Highlands of Victoria, mostly in montane and lower subalpine situations, at about $750-1500(-1800) \mathrm{m}$ altitude. Sometimes in peaty sites but usually on siliceous soil developed on granite, gneiss, quartzite or conglomerate. On rocky slopes or in grassland, herbfield, eucalypt woodland and at the edges of bogs. (Fig. 13).

This taxon was referred to as 'Parahebe derwentiana subsp. B' in Jacobs \& Pickard (1981).

It is absent from the Northern Tablelands of New South Wales, although the higher areas would provide apparently suitable habitats. Also it does not occur in Tasmania 


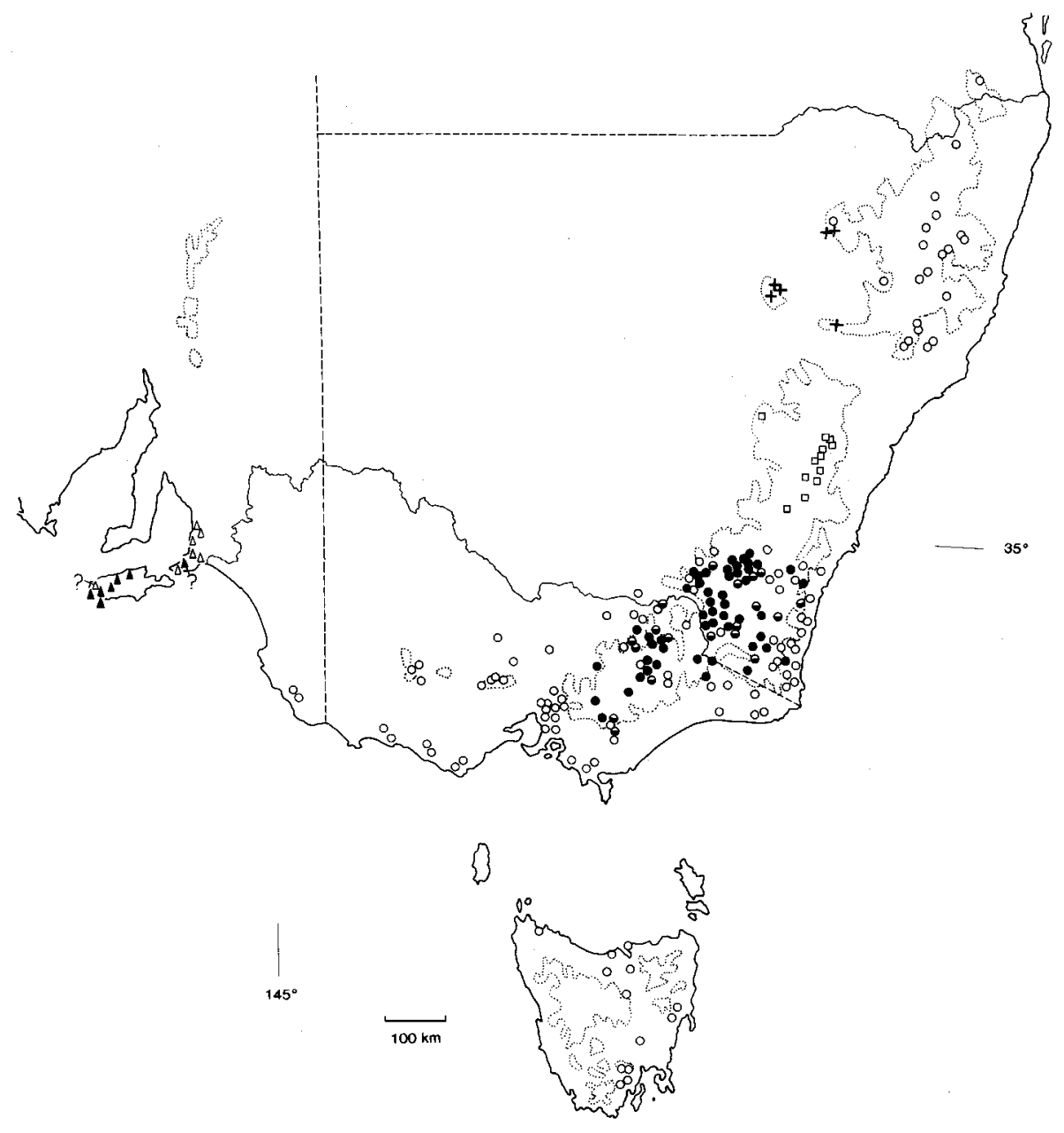

Figure 13. Distribution of $D$. derwentiana: subsp. derwentiana $(O)$, subsp. maideniana $(\bullet)$, intergrades between subsp. derwentiana and subsp. maideniana $(\ominus)$, subsp. homalodonta $(\triangle)$, subsp. anisodonta (ム), subsp. subglauca ( $\square)$; D. velutina (+). The dotted line shows the $610 \mathrm{~m}$ (c. 2000 ft) contour.

where there are extensive montane areas and where $D$. derwentiana is uncommon or absent at the higher altitudes.

Toward its lower altitudinal limit there is extensive intergradation with subsp. derwentiana. Morphologically intermediate stands may be relatively uniform (e.g. $1 \mathrm{~km}$ W of Tuross Falls, SE of Countegany, Johnson, 5 Jan 1968, NSW 85492), or very variable (e.g. between Mountain Creek and Trappers Gap, Tawonga district, Vic., Rodd, 16 Apr 1968 (NSW 101633-5) (Fig. 12c, d, e).

Selected Specimens: New South Wales: Southern Tablelands: Sandhills Ra. (E of Queanbeyan), Moore 1748, 9 Sep 1952 (CANB); Bulls Head, Brindabella Ra., Campbell 32, 22 Mar 1959 (CANB); between Pryors Hut and Mt Gingera, Brindabella Ra., Coveny 11537 \& Hind, 19 Jan 1983 (NSW, 
AD, CHR, K, MO); Fishing Gap, Mt Tidbinbilla, ACT, Burbidge 2751, 27 Jan 1948 (CANB); Brindabella Ra., Lothian, 16 Jan 1954 (AD); Mt Franklin, ACT, Burbidge 1713, Feb 1947 (CANB); Rules Point to Brindabella Rd, above Goodradigbee R., Walker, Dec 1962 (CANB); c. $4.8 \mathrm{~km} \mathrm{SE}$ of Captains Flat on rd to Braidwood, Briggs 3207, 25 Dec 1969 (NSW, LE); Laurel Hill, 15 miles [24 km] N of Tumbarumba, Cambage 837, 14 Mar 1903 (NSW); Happy Jacks Plain, Phillips, 20 Mar 1962 (CBG), turn-off to Island Bend on Mt Kosciusko Rd, McKee 6987, 5 Jan 1960 (CANB); Pretty Point, Mt Kosciusko, Maiden \& Forsyth, Jan 1899 (NSW 6200); New Chum Hill, Kiandra, Briggs 2586, 11 Feb 1969 (NSW, MEL); Dead Horse Gap, Bishop 365 \& Gunnell, 14 Jan 1985 (NSW, MEL); Smiggin Holes, Mt Kosciusko, Johnson \& Constable, 23 Jan 1951 (NSW 18409); Wallace Craige Lookout SW of Ingebyra, Briggs, 25 Dec 1964 (NSW 90671). Victoria: Midlands: SE slopes of Mt Buangor, $21 \mathrm{~km}$ NW of Beaufort, Chinnock 1365, 29 Dec 1973 (AD, BRI, NSW). Victorian Highlands: Mt Beauty area, c. $16 \mathrm{~km}$ E of Bright, Hill 1315, 1 Jan 1964 (AD). Snowfields: between Howmans Gap and Falls Ck, Aston 222, 29 Dec 1958 (MEL); N slope of Rocky Knobs, Bogong High Plains, Eichler 14691, 3 Feb 1958 (AD); Mt Hotham, Rae, Feb 1937 (MEL); Mt Hump, near Mt Buller, Whaite, 11 Jan 1949 (NSW 7656); [Mt] Buffalo, Pryor, 1 Mar 1949 (CBG); Snowy Plains 3 miles [4.8 km] N of Mt Reynard, Muir 4544, 18 Jan 1967 (MEL). East Gippsland: Avalanche Lookout, 5 miles [8 km] from Suggan Buggan R. toward Wulgulmerang, Carroll, 18 Dec 1965 (CBG).

The following are examples of collections more or less intermediate in morphology between subsp. derwentiana and subsp. maideniana:

New South Wales: Southern Tablelands: near Coree Mtn, Story 6528, 9 Jul 1959 (CANB); Upper Cotter, Brooker 1047, 2 Jan 1966 (GAUBA); Rules Point to Brindabella Rd, Walker 961, Dec 1962 (CANB, NSW); Laurel Hill, NE of Tumbarumba, McBarron, 27 Dec 1948 (NSW 7246); Thredbo R., Maiden \& Forsyth, Jan 1899 (NSW 6193); Dicky Cooper Ck, Gittins 424, Jan 1962 (NSW); Brown Mt E of Nimmitabel, Gray 5669, 27 Jan 1965 (CANB). Victoria: Midlands: S side of Granya Gap, NE of Tallangatta, Rodd, 16 Apr 1968 (NSW 101631). Victorian Highlands: Tali Karng, Muir 2979, 31 Dec 1963 (MEL); $13 \mathrm{~km} \mathrm{~S}$ of Woods Point on Walhalla Rd, Briggs, 30 Dec 1964 (NSW 72452); Thompson R., Howitt, 1882 (MEL). Snowfields: [Mt] Buffalo, Baker, Mar 1910 (MEL); Mt St Bernard, Maiden, Jan 1900 (NSW 6173). East Gippsland: Cann R. 4 miles [6.5 km] S of Vic.N.S.W. border, Fagg, 19 Jan 1963 (AD).

\section{4c. Derwentia derwentiana subsp. homalodonta B. Briggs \& Ehrend., subsp. nov.}

Inter subspecies $D$. derwentianae combinatione sequenti characterum distinguitur: capsulae glabrae non emarginatae, laminae foliorum basi cordatae non pruinosae et dentibus antrorsis uniformiter brevibus instructae.

TYPE: SOUTH Australia: Mt Lofty, c. $15 \mathrm{~km}$ south-east of Adelaide, Herb. R. Tate, 4 Dec 1880; holo AD 96645003.

Leaves sessile; laminae narrow-ovate, the base cordate, the apex acuminate, 65-120 $\mathrm{mm}$ long, 17-40 mm broad, leaf index 2.4-3.8 (-5); teeth shallow, uniform in spacing and depth, antrorse and often incurved at the apex, dentation index 1.01-1.1; the lower surface not pruinose (but sometimes with scattered small whitish patches in dried specimens). Racemes: floriferous portion 9-15 cm long. Pedicels $3-4.5 \mathrm{~mm}$ long in fruit. Capsules glabrous, the apex obtuse. Chromosome number: $n=20$. (Fig. 14).

Distribution And habitat: South Australia; Adelaide district to Port Elliot and apparently also Kangaroo Island. Relatively moist sites in gullies and near creeks. (Fig. 13).

CONSERVATION STATUS: not well known but may be at risk, code $3 \mathrm{~K}$.

The subspecific epithet is derived from the Greek homalos, even, level or uniform and odous, odontos, a tooth, referring to the uniform-sized leaf teeth.

The eastern boundary of subsp. homalondonta, isolating it from subsp. derwentiana, is the Murray River valley and the low-lying area of Pleistocene fluvial and lacustrine 
deposits and calcareous dunes to the south-east of the present position of the Murray River mouth. Kangaroo Island was continuous with the Fleurieu Peninsula (west of Port Elliot) until Pleistocene or Holocene time (David 1950).

Subspecies homalodonta and anisodonta are closely allied. Their distribution and variation require more study and the following two specimens depart from the general areas of occurrence of the subspecies and are mapped with some doubt in Fig. 13. Flinders Chase, western end Kangaroo I., Cleland 25 Nov. 1945 (AD) has relatively broad leaves and shallow uniform teeth, as in subsp. homalodonta, although recorded from a region where subsp. anisodonta occurs. By contrast, the following specimen has narrow leaves and spreading teeth that would identify it as subsp. anisodonta but is from a locality that also supports subsp. homalodonta: Kyeema Conservation Park, Hundred [of] Kuitpo, Heddle KCP109, Jan 1974 (AD).

Selected specimens: South Australia: Southern Lofty: Port Adelaide, Blandowsky, 1850 (MEL); Upper Sturt, Ashby, Jan 1920 (ADW); inter Port Adelaide et Hahndorf, Blandowsky, 1849 or 1850 (MEL); Onkaparinga R., Griffith, 31 Dec 1906 (AD); Hindmarsh Tiers, Fleurieu Peninsula, I. McArthur, Jan 1969 (AD, CANB, NSW 118325); Wild Dog Ck, Myponga, Dunstan, Nov 1945 (AD); waterfall off Inman Valley, J.B. Cleland, Jan 1928 (AD); near Port Elliot, Hussey, Jan 1895 (AD); Kyeema Conservation Park, Spooner 6751, 28 Oct 1979 (AD).

\section{4d Derwentia derwentiana subsp. anisodonta B. Briggs \& Ehrend., subsp. nov.}

Inter subspecies $D$. derwentianae combinatione sequenti characterum distinguitur: capsulae glabrae non emarginatae, laminae foliorum basi cuneata, non pruinosae et dentibus grossiusculis irregularibus patentibusque instructae.

TyPe: South Australia: Kelly Hill, c. 13 km east-north-east of Cape du Couedic, S.W. Kangaroo Island, P.G. Wilson 657, 2 Nov 1958; holo AD 95934088; iso M.

Leazes sessile or with petioles c. $3 \mathrm{~mm}$ broad and to $3 \mathrm{~mm}$ long; laminae narrow or very narrow ovate, the base abruptly cuneate, the apex acuminate, (50-)90-140 $\mathrm{mm}$ long, (10-)14-28 mm broad, leaf index 5-6.8; teeth coarse, usually irregular in spacing and depth, spreading, dentation index 1.08-1.25; the lower surface not pruinose (but sometimes with small scattered white patches in dry specimens). Racemes: floriferous portion to c. $25 \mathrm{~cm}$ long. Pedicels c. $4 \mathrm{~mm}$ long. Capsules glabrous, subacute. (Fig. 14).

Distribution AND habITAT: Kangaroo Island, South Australia. Relatively moist sites in gullies and near creeks. (Fig. 13).

CONSERVATION STATUS: Represented in conserved areas but with restricted distribution, code $3 \mathrm{KC}$.

The subspecific epithet is derived from the Greek anisos, unequal, and odous, odontos, a tooth, referring to the uneven-sized leaf teeth.

Selected specimens: South Australia: Kangaroo I.: Stokes Bay, Jackson 996, Nov 1973 (AD); Karatta Caves, Cashmore, 20 Nov 1933 (ADW); Cygnet R., Eardley, Nov 1933 (ADW); Wights, Cygnet R., Cashmore, 19 Dec 1933 (ADW); Middle R., Ashby, Oct 1905 (NSW 6182); Stunsail Boom R., south coast rd, Eichler 15423, 12 Nov 1958 (AD); Ravine des Casoars, Cleland Mar 1926 (AD); Rocky R., Cleland Mar 1926 (AD), Dec 1934 (AD); Breakneck R., Western Flinders Chase, Spooner 3799, 12 Dec 1974 (AD); Flinders Chase $35^{\circ} 52^{\prime} \mathrm{S} 136^{\circ} 42^{\prime}$ E, --, Oct 1922 (AD); Kellys Hill, near the caves, E. Briggs, Oct 1973 (NSW 224343, AD, BRI, CANB, CBG, CHR, MEL, K, L, LE, MO); Kellys Hill Caves, Phillips 27 Sep 1965 (CBG); Kangaroo I., Staer, Mar 1911 (NSW 6183). 


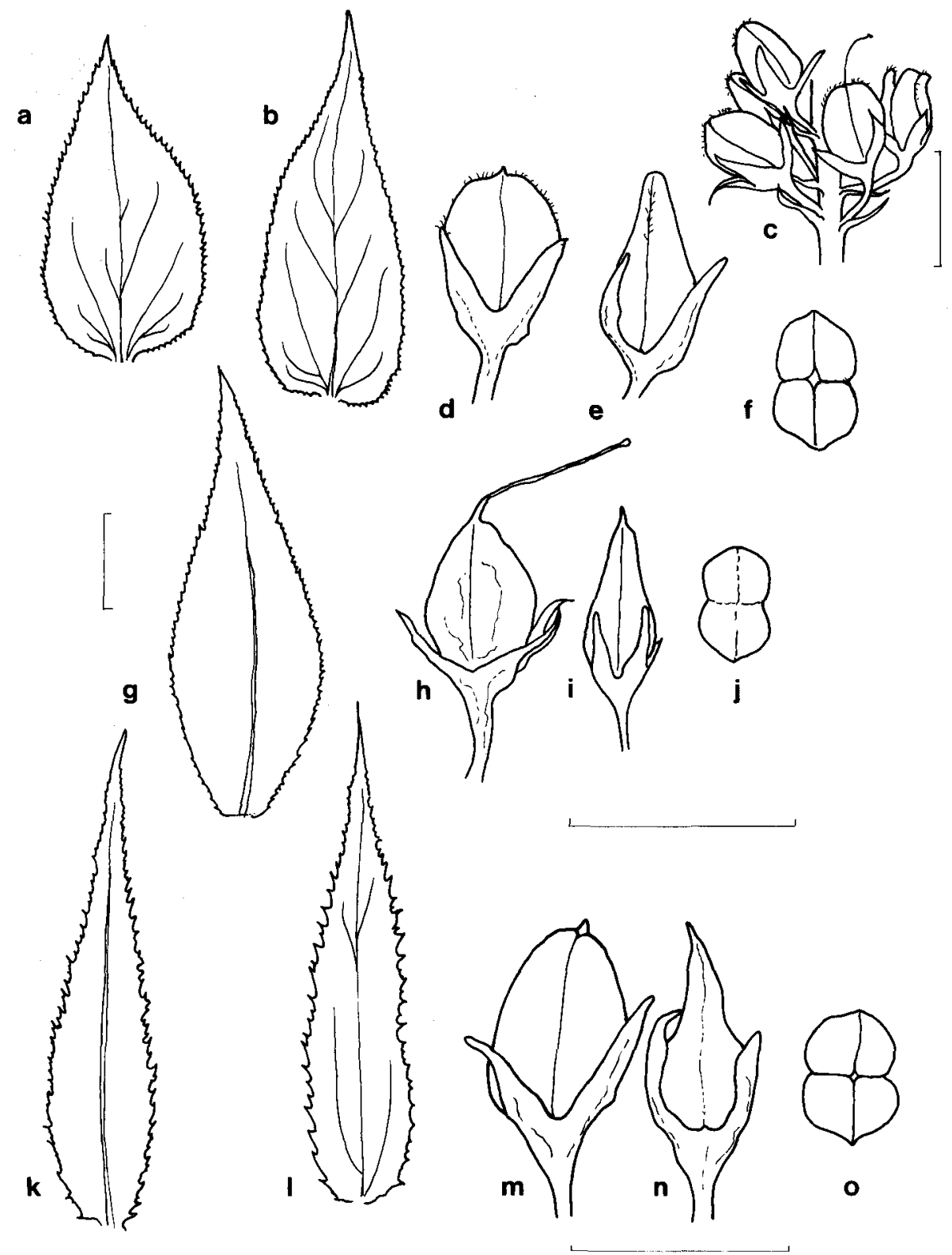

Figure 14. D. derwentiana subsp. maideniana. a-b, leaves; $\mathbf{c}$, part of fruiting inflorescence; $\mathbf{d}-\mathbf{f}$, capsule with calyx - lateral, abaxial and apical views; a from Muir 4544; b-f CBG 7744.

$D$. derwentiana subsp. homalodonta. $\mathbf{g}$, leaf; $\mathbf{h}-\mathbf{j}$, capsule with calyx - lateral, abaxial and apical views; a from AD 96645003; $h-j$ NSW 6182. Scale bars: $a-b, g, k-l=2 \mathrm{~cm}, c=2 \mathrm{~mm}, \mathrm{~d}-\mathrm{f}, \mathrm{h}-\mathrm{j}$, $\mathrm{m}-\mathrm{o}=2.5 \mathrm{~mm}$.

D. derwentiana subsp. anisodonta. $\mathbf{k}-\mathbf{l}$, leaves; $\mathbf{m}-\mathbf{0}$, capsule with calyx - lateral, abaxial and apical views; $\mathrm{k}$ from Wilson 657 (holotype); 1 Eichler 15423; m-o ADW 1904. Scale bars: $\mathrm{a}-\mathrm{c}=2 \mathrm{~cm}$, d $=2 \mathrm{~mm}, \mathrm{e}-\mathrm{g}=2.5 \mathrm{~mm}$. 
4e. Derwentia derwentiana subsp. subglauca B. Briggs \& Ehrend., subsp. nov.

Inter subspecies $D$. derwentianae combinatione sequenti characterum distinguitur: capsulae emarginatae glabraeque; laminae foliorum basi cuneata, infra plus minusve pruinosae et dentibus grossiusculis patentibus vel antrorsisque instructae.

TyPE: New SOUTh WALES: Central Tablelands: Jenolan Caves Road, alt. $1350 \mathrm{~m}$, E.F. Constable, 9 March 1950; holo NSW 11133; iso CANB.

Leaves sessile or very shortly petiolate; petioles to $5 \mathrm{~mm}$ long, 3-4 $\mathrm{mm}$ broad; laminae narrow or very narrow ovate, the base cuneate, the apex acuminate, 75-145 mm long, $18-50 \mathrm{~mm}$ broad, leaf index 2.7-7.5; teeth rather coarse, spreading or antrorsely curved, dentation index 1.03-1.14, the lower surface pruinose in old leaves (pruinosity scarcely noticeable in young leaves and sometimes destroyed by heat-drying of specimens). Racemes: floriferous portion 8-25 cm long. Pedicels 5-10 mm long in fruit. Capsules emarginate, glabrous. Chromosome number (Fig. 1e): $n=20$. (Fig. 15).

Distribution AND HABiTAT: Central Tablelands of New South Wales, south of Lithgow. On granite, shale, sandstone and probably limestone, in moist situations in Eucalyptus forest, often on slopes and rocky gully situations, at about $780-1350 \mathrm{~m}$ alt. (Fig. 13).

The subspecific epithet derives from the Latin $s u b$-, under or somewhat, and glaucus, grey or bluish green, referring to the greyish undersides of the leaves.

This taxon was referred to as 'Parahebe derwentiana subsp. C' in Jacobs \& Pickard (1981).
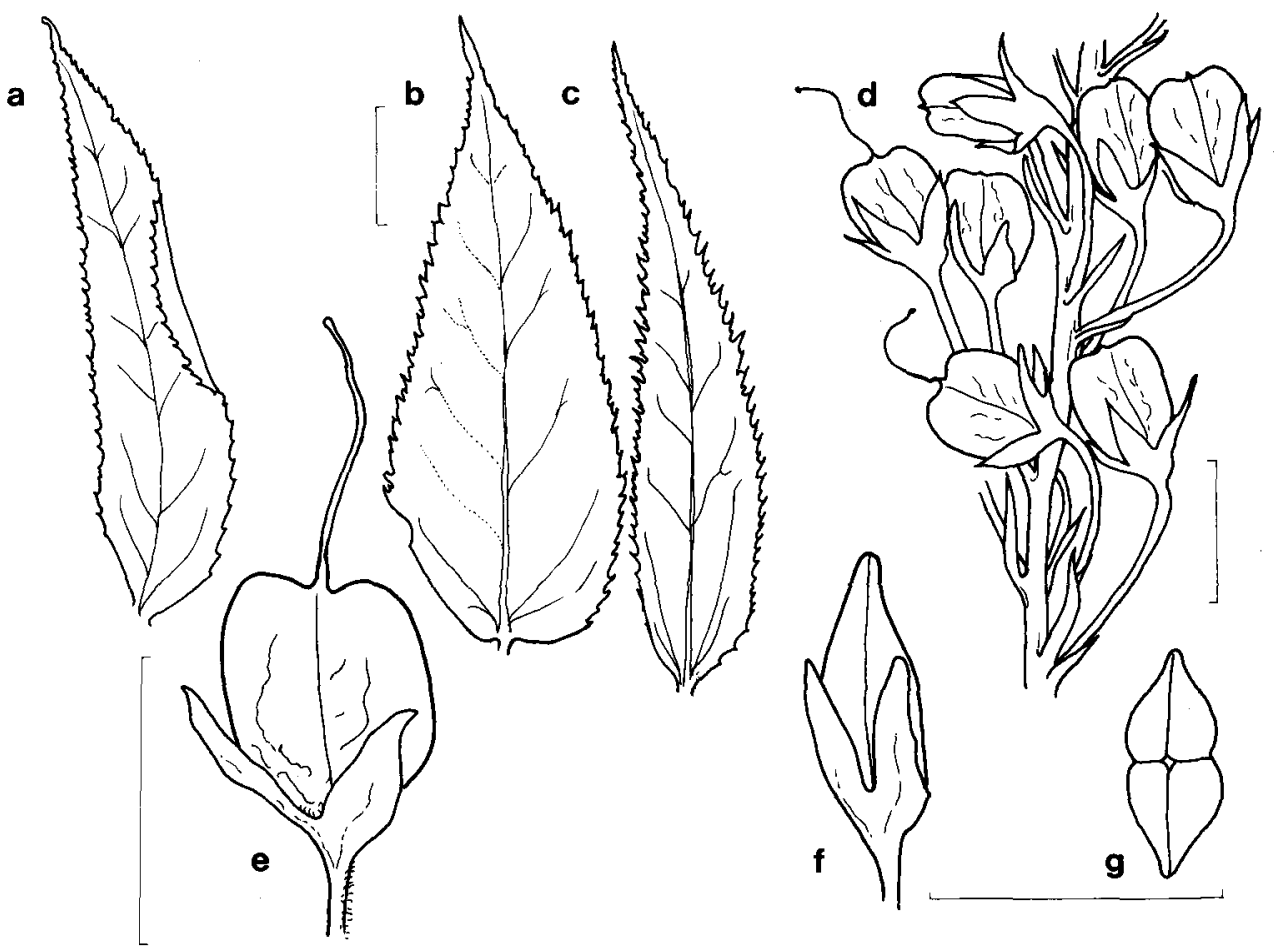

Figure 15. D. derwentiana subsp. subglauca. a-c, leaves; $d$, part of fruiting inflorescence; $\mathbf{e}-\mathbf{g}$, capsule with calyx - lateral, abaxial and apical views; from Constable NSW 11133 (holotype). Scale bars: $\mathrm{a}-\mathrm{c}=2 \mathrm{~cm}, \mathrm{~d}=2 \mathrm{~mm}, \mathrm{e}-\mathrm{g}=2.5 \mathrm{~mm}$. 
It is not known to overlap geographically or intergrade with any other of the subspecies of $D$. derwentiana and is the most distinctive of them. The glabrous emarginate ovary and pruinose lower surfaces of the leaves may suggest a possible origin from hybridisation between subsp. derwentiana and D. blakelyi. However, the indumentum of vegetative parts as well as corolla size and colour are among features in which this resembles other subspecies of $D$. derwentiana and shows no approach to $D$. blakelyi.

Selected specimens: New South Wales: Central Tablelands: Mt Canobolas, Briggs 6244 E Johnson, Nov 1975 (NSW); Esk Bank [Eskbank], Hamilton, Dec 1910 (NSW 6165); Browns Gap, 2 miles [3.2 km] S of Lithgow, Briggs 1006 \& Johnson, 26 Nov 1966 (NSW 101606, CANB); near Hassans Walls, Fletcher, Nov 1893 (NSW 6186, AD, MEL, MO); Mt Victoria, Hamilton (NSW 6191); Blue Mtns, Woolls (MEL); Hampton, Briggs 1012 \& Johnson, 26 Nov 1966 (NSW CANB, CHR, K, MEL, MO); near Hampton on Jenolan rd, Vickery, 28 Nov 1948 (NSW 6969); Gingkin near Jenolan, Maiden, Mar 1912 (NSW 6160); Jenolan Caves, Blakely, Nov 1899 (NSW 6163), Dec 1899 (NSW 16373); Jenolan, Johnston, Jan 1904 (CANB); Jenolan Caves, Duff (MEL); Murdering Gully, Kanangra, 10 miles [16 km] SE of Jenolan Caves, Constable 5904, 23 May 1965 (NSW, AD, CHR); Thurat Rivulet between Kanangra Tops and Thurat Tops, Johnson, 3 Oct 1948 (NSW 6530); 1 mile [1.6 km] W of Kanangra Plateau, Coveny, 15 Apr 1967 (NSW 118259); Mt Werong, 25 miles [40 km] S of Oberon, Constable 4085, 27 Nov 1962 (NSW); 1 mile [1.6 km] S of Mt Werong, Briggs 1102 \& Johnson, 29 Nov 1966 (NSW 95688 - 2 sheets, CBG, LE), Briggs 1103 (NSW, K); 2 miles [c. $3 \mathrm{~km}$ ] NW of Wombeyan Caves, Briggs \& Johnson, 29 Nov 1961 (NSW 101562 - 2 sheets, AD); Taralga, Cheel, 12 Dec 1919 (NSW 6154).

\section{Derwentia velutina $B$. Briggs $\mathcal{E}$ Ehrend., sp. nov.}

Affinis $D$. derwentianae sed characteribus sequentibus distinguitur: omnes partes vegetativae pilis perbrevibus $(0.1-0.3 \mathrm{~mm}$ longis) vestitae; caules per annis pluribus crescentes tunc decumbentes, folia sectione transversa saepe V-formia.

TyPe: New South Wales: North Western Slopes: Siding Spring Mountain, $800 \mathrm{~m}$ alt., on road to Mopera Gap, Warrumbungle Mountains, F. Ehrendorfer 9201, B. Briggs \& L. Johnson, 24 Dec 1966; holo NSW; iso AD, CANB, CHR, MEL, WU.

Slender erect softy woody shrub, 0.5-1.7 m tall, densely and evenly covered with very short fine hairs on the stems, leaves, part of the calyx lobes, ovary, and the outer surface of the corolla (but not the inner surface of corolla and lower half of the calyx lobes); the hairs spreading or recurved, $0.1-0.3 \mathrm{~mm}$ long, of 1-3 cells. Stems several from an erect or prostrate woody rootstock, softly woody, erect, mostly unbranched below the inflorescence, terete, $3.5-7 \mathrm{~mm}$ diam., the basal $2-3 \mathrm{~cm}$ often prostrate and with adventitious roots, the longest internodes $0.5-2(-4.5) \mathrm{cm}$ long; each stem flowering for up to 3 seasons before becoming decumbent and dying back to the rootstock, commonly continuing growth during flowering; sometimes with erect lateral shoots developed from old decumbent branches. Leaves sessile, spreading or recurved, often $\mathrm{V}$-shaped in transverse section, narrow-ovate, (30-)45-90 mm long, (7-)10-16 mm broad, leaf index 3.5-7.5, tapering gradually to the narrow base and the acute or acuminate apex, with 15-30 apiculate teeth on each side (the teeth spreading, \pm irregular, commonly alternately large and small), dentation index $1.05-1.3$, with 3-5 nerves from the base and 4-6 major nerves from the midrib, the margin slightly thickened but not recurved. Racemes single or usually opposite at each of 1-5(-9) upper nodes of one season's growth, floriferous portion (9-)15-30 cm long with 50-160 flowers; the peduncle $1.5-5(-7) \mathrm{cm}$ long. Bracts subulate, $5-14 \mathrm{~mm}$ long. Fruiting pedicels $3-5(-7) \mathrm{mm}$ long. Calyx lobes subulate or narrow-triangular, equalling or exceeding the capsules, $4.5-9 \mathrm{~mm}$ long and $1-1.5 \mathrm{~mm}$ broad in fruit. Corolla violet-blue or pale lavender with darker nerves, $7.5-11 \mathrm{~mm}$ long, the throat with hairs c. $1.5 \mathrm{~mm}$ long; adaxial lobe broad-ovate, acute or obtuse, $3.5-5 \mathrm{~mm}$ broad; abaxial lobe narrowovate, usually acute, $1.5-2.5 \mathrm{~mm}$ broad. Stamen filaments $4-6 \mathrm{~mm}$ long; anthers 1-1.5 
mm long. Ovules in 2-4 irregular rows on a narrow vertical placenta. Capsules not glossy, compressed, ovate, 4-6 $\mathrm{mm}$ long, 3-5 $\mathrm{mm}$ broad, 2-2.8 $\mathrm{mm}$ thick, obtuse or truncate, the margin with short stiff hairs, dehiscing by a septicidal split to (or almost to) the base and splitting loculicidally for $1 / 3$ of the distance to the base; persistent style 5.5-7 mm long with soft twisted hairs near the base. Seeds $10-30,1-1.5 \mathrm{~mm}$ long, c. $0.8 \mathrm{~mm}$ broad. Chromosome number: $n=20$. (Fig. $4 \mathrm{~d}, 16$ ).

DisTRIBUTION AND HABITAT: Three separate elevated areas in the western parts of the Northern Tablelands and North Western Slopes of New South Wales: the Nandewar Range E of Narrabri, the Warrumbungle Mountains and the northern slopes of the Liverpool Range. In eucalypt woodland and in dense scrub, also commonly a coloniser of disturbed sites. In moist or rather dry sites, at about 750-1200 m alt. (Fig. 13).

The epithet is derived from the post-classical Latin velutinus, velvety, referring to the fine short erect hairs on most parts of the plant.

The species was referred to as 'Parahebe sp. D' in Jacobs \& Pickard (1981).

Selected sPecimens: New South Wales: Northern Tablelands: Coryah Gap, Nandewar Ra., Briggs, 2 Mar 1961 (NSW 53767); West Kaputar Lookout, Mt Kaputar Natl Park, R. Pullen 10.380, 15 Mar 1977 (CANB, K, NSW); Mt Kaputar plateau, Briggs 4298 \& Johnson, 5 Jun 1971 (NSW, CHR); range between Coomoo Coomoo $\mathrm{Ck}$ and Henrys $\mathrm{Ck}, \mathrm{c}$. 38 miles $[61 \mathrm{~km}] \mathrm{WSW}$ of Quirindi, Pickard \& Coveny 1158, Jun 1969 (NSW). North Western Slopes: Siding Spring Mtn, Warrumbungle Mtns, Johnson, 26 Mar 1967 (NSW 95847); Warrumbungle Mtns, Hartley, 5 Jun 1966 (NSW 82407); Warrumbungle Ra., Forsyth, Oct 1899 (NSW 6211); Timor Rock to Mopera (as Mobara) Rock, Warrumbungle Ra., Salasoo 2289, Jan 1962 (NSW); Mt Wombelong, Warrumbungle Ra., $30 \mathrm{~km}$ W of Coonabarabran, H. Streimann 524, 5 Dec 1973 (CBG, A, AD, K, NSW).

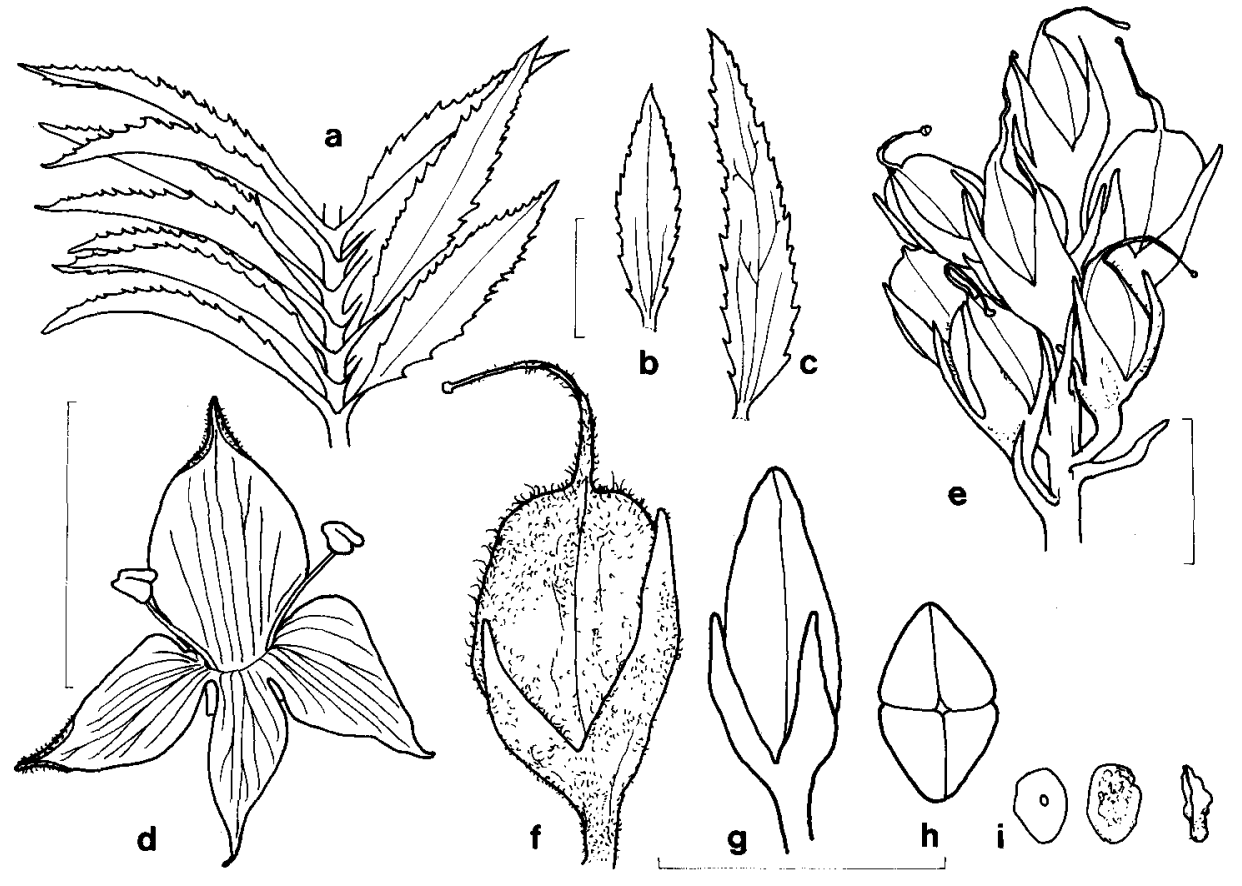

Figure 16. D. velutina. $\mathbf{a}$, leafy branch; $\mathbf{b}-\mathbf{c}$, leaves; $\mathbf{d}$, corolla and stamens; $\mathbf{e}$, part of fruiting inflorescence; $\mathbf{f}-\mathbf{h}$, capsule with calyx - lateral, abaxial and apical views; $\mathbf{i}$, seeds - adaxial, abaxial and side views; $a$ and $b$ from Pickard \& Coveny 1158; c-d Ehrendorfer 9201 (holotype); fi Johnson NSW 95847. Scale bars: $\mathrm{a}-\mathrm{c}=2 \mathrm{~cm}, \mathrm{~d}=5 \mathrm{~mm}, \mathrm{e}=2 \mathrm{~mm}, \mathrm{f}-\mathrm{i}=2.5 \mathrm{~mm}$. 


\section{Derwentia blakelyi $B$. Briggs $\mathcal{E}$ Ehrend., sp. nov.}

A $D$. perfoliata et $D$. arcuata capsula late obovata, compressa, emarginata, (3-)4-6.5 $\mathrm{mm}$ longa, 3-3.5 mm lata, 1.2-2 $\mathrm{mm}$ crassa differt.

Type: New SOUTH Wáes: Central Tablelands: On hill west of Clarence [Railway] Platform, W.F. Blakely \& W.J. Buckingham, 31 Dec 1938; holo NSW 6221; iso AD, CANB, CHR, K, MEL.

Softly woody small slender shrub, $0.15-0.7 \mathrm{~m}$ tall, vegetative parts, calyx, and ovary glabrous and glaucous. Stems one to several from a narrow woody rootstock, mostly erect and unbranched below the inflorescence, at first herbaceous but becoming softly woody, $15-40(-70) \mathrm{cm}$ long, terete, $1.5-4 \mathrm{~mm}$ diam., each stem flowering in only one season, commonly continuing growth above the nodes subtending the racemes but not flowering again before dying back to the base, the longest internodes $1.5-6 \mathrm{~cm}$ long, the basal $1-3 \mathrm{~cm}$ often with adventitious roots but usually erect. Leaves sessile, usually recurved, $\mathrm{V}$-shaped in transverse section, ovate to very narrow-ovate, 25-55 $\mathrm{mm}$ long, (7-)10-20(-27) $\mathrm{mm}$ broad, leaf index 1.8-4(-5.5), with 8-18 shallow teeth on each side, dentation index 1.02-1.2, with 3-7 nerves from near the base and usually 1-2 on the midrib, the base cordate or truncate or cuneate, the apex acute or subacute, the margin thickened. Racemes single or usually opposite at each of 1-3 upper nodes, floriferous portion (2.5-)8-40 cm long, with (6-)15-35(-70) flowers; the peduncle 4.5$14 \mathrm{~cm}$ long. Bracts linear, acute, $2-3.5 \mathrm{~mm}$ long. Pedicels $2.5-6 \mathrm{~mm}$ long in fruit. Calyx lobes narrow-elliptic, obtuse, $3-5.5 \mathrm{~mm}$ long and $0.7-1.3 \mathrm{~mm}$ broad in fruit. Corolla bright blue-violet, 6-7 mm long, with short hairs in the throat; adaxial lobe ovate, obtuse to acute, $2.5-4 \mathrm{~mm}$ broad; abaxial lobe narrow-ovate, subacute, $2-2.5 \mathrm{~mm}$ broad. Stamen filaments violet, $2-3.5 \mathrm{~mm}$ long; anthers cream, 1.4-2 $\mathrm{mm}$ long. Ovules few in 2 vertical rows. Capsules glabrous, glaucous, broad-obovate, slightly or distinctly emarginate, compressed, (3-)4-6.5 $\mathrm{mm}$ long, 3-5.5 $\mathrm{mm}$ broad. 1.2-2 mm thick, splitting septicidally and along the upper margin and eventually splitting to the base along both sutures; style usually persistent, glabrous, 4-5 mm long. Seeds 2-12, 1-1.5 mm long. (Fig. 4e, 17).

DistribUtion AND HABITAT: Central Tablelands of New South Wales: at several locations in the region north, east and west of Lithgow, but all within a range of $100 \mathrm{~km}$. In eucalypt forest or woodland on soils of rather low fertility on shale or sandstone. (Fig. 19).

CONSERVATION STATUS: The restricted distribution and possible occurrence in Wollemi National Park leads to a coding of $2 \mathrm{R}$ or $2 \mathrm{RC}$.

The epithet commemorates William Faris Blakely (1875-1941), botanist at NSW, who collected this species and recognised its distinctiveness, and who made notable studies of many plant groups but especially of eucalypts.

This species was referred to as 'Parahebe sp. E.' in Jacobs \& Pickard (1981). Beadle et al. (1963) refer to it in their comment that intermediate forms between [Derwentia perfoliata and $D$. derwentiana] occur, e.g. near Clarence'. In a later edition (Beadle et al. 1982) this is replaced by a comment that 'Specimens previously thought to be intermediates between these two species are probably an undescribed species'.

SPecimens eXamined: New South Wales: Central Tablelands: Coricudgy Ra., Baker, Oct 1897 (NSW 156175); Mt Horrible, Upper Limekilns rd, Constable, 19 Mar 1955 (NSW 39743); W slope of Mt Horrible, between The Limekilns and Palmers Oakey, Johnson 8120, 5 May 1975 (NSW); on track at the head of the long swamp E of Lithgow Water-Works, Blakely, 31 Dec 1938 (NSW 6224); 1.3 km NW of Clarence, Briggs 6976, 3 Dec 1978 (NSW, AD, CHR, MEL); Clarence, 1/3 mile [0.5 km] NW of Railway Station, Ehrendorfer, Briggs \& Johnson, 23 Oct 1966 (NSW 95678, CANB, MO), Briggs 1410a, 26 Dec 1967 (NSW, BRI, CBG, HO, L, LE, RSA), Briggs 1410b (NSW); 
Shepherds Swamp, Clarence, Blakely \& Buckingham, 30 Dec 1938 (NSW 6223, CANB, CHR); on the W side of Shepherds Swamp, Clarence, Blakely \& Buckingham, 26 Nov 1938 (NSW 6226); head of the long swamp E of The Clay Pits, Blakely \& Buckingham, 31 Dec 1938 (NSW 6222); along the old railway line, Clarence, Blakely \& Buckingham, 24 Nov 1939 (NSW 6225, CANB, CBG, K, LE, MO); Clarence, Burgess, 26 Oct 1962 (CBG).
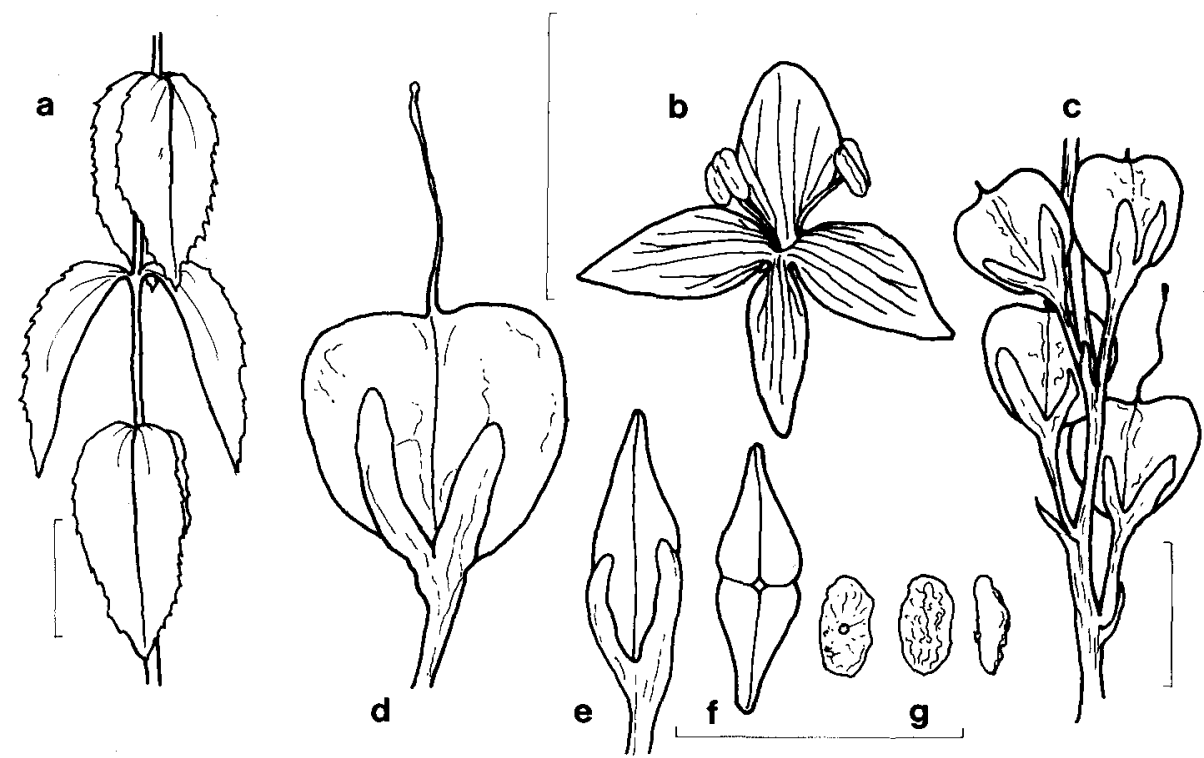

Figure 17. D. blakelyi. a, leafy branch; $\mathbf{b}$, leaf; c, corolla with stamens; d, part of fruiting inflorescence; e- $\mathbf{g}$, capsule with calyx - lateral, abaxial and apical views; $\mathbf{h}$, seeds - adaxial, abaxial and side views; a-c from Briggs 1410a; d-h Blakely \& Buckingham NSW 6221 (holotype). Scale bars: $\mathrm{a}-\mathrm{b}=2 \mathrm{~cm}, \mathrm{c}=5 \mathrm{~mm}, \mathrm{~d}=2 \mathrm{~mm}$, e-h $=2.5 \mathrm{~mm}$.

\section{Derwentia arcuata $B$. Briggs $\mathcal{E}$ Ehrend., sp. nov.}

A D. blakelyi capsula ellipsoidea, minus compressa, non emarginata, et a $D$. perfoliata foliis recurvis sectione transversa V-formibus, semper dentatis, differt.

TyPe: New SOUTH WALEs: Northern Tablelands: Biscuit Ck, $71 / 2$ miles [12 km] NW of Ebor, N.C. Ford, 10 Jan 1958; holo NSW 42793.

Vegetative parts, calyx, and ovary glabrous and glaucous. Stems several from a narrow woody rootstock or from elongated underground rhizomes, mostly erect and unbranched below the inflorescence, at first herbaceous, becoming softly woody, often \pm prostrate at the base, $30-75 \mathrm{~cm}$ long, terete, $1.8-4 \mathrm{~mm}$ diam., the longest internodes $1.5-6 \mathrm{~cm}$ long; each stem flowering in only one season, commonly continuing growth above the nodes subtending the lateral racemes but not flowering again before dying back to the base. Leaves sessile, usually recurved and V-shaped in transverse section, ovate to narrow-ovate, $32-90 \mathrm{~mm}$ long, $10-45 \mathrm{~mm}$ broad, leaf 
index 1.5-3.5, with 6-15 coarse spreading or antrorse teeth on each side, dentation index 1.06-1.2, usually with 7 nerves from near the base and 1-2 on the midrib, the base cordate or cuneate, the apex acute, the margin thickened. Racemes single or usually opposite at each of 1-4(-6) upper nodes, floriferous portion (3-)9-35 cm long, with (8-)20-85 flowers; the peduncle 4-12 cm long. Bracts linear, acute, 2-4 mm long. Pedicels 3-5 mm long in fruit. Calyx lobes linear or narrow-elliptic, acute, 4-5 mm long and $0.8-1.2 \mathrm{~mm}$ broad in fruit. Corolla lilac, 9.5-11 $\mathrm{mm}$ long, with rather long (c. 1 $\mathrm{mm}$ ) hairs in the throat; adaxial lobe elliptic, obtuse or subacute, $5-7 \mathrm{~mm}$ broad; abaxial lobe narrow-ovate, subacute, $2.5-3.5 \mathrm{~mm}$ broad. Stamen filaments $4.5-6.5 \mathrm{~mm}$ long; anthers 1.5-2 mm long. Ovules in 2 irregular vertical rows. Capsules glabrous, glaucous, ellipsoidal, obtuse or truncate, slightly compressed, (4.5-)6-9.5 mm long, 3$5 \mathrm{~mm}$ broad, $2.2-2.8 \mathrm{~mm}$ thick, dehiscing by a septicidal split and eventually splitting to the base septicidally and $1 / 4-1 / 2$ of the distance to the base loculicidally; style glabrous, persistent or the upper part deciduous, the basal $0.5 \mathrm{~mm}$ thickened and splitting longitudinally at dehiscence. Seeds 4-20, ovoid but irregular in outline, the margin undulate, 1-2 mm long, c. $1 \mathrm{~mm}$ broad. (Figs. 4e, f, 18).

Distribution AnD habitat: Northern Tablelands of New South Wales, and extending to closely adjacent areas of the North Western Slopes. Usually in eucalypt woodland, often on shallow soil with rock outcrops, on basalt and granite, 750-1600 m alt. (Fig. 19).

The epithet is derived from the Latin arcuatus, curved, like a bow, referring to the recurved leaves.

This species was included, with a brief English description and illustration, as 'Parahebe arcuata' Briggs et Ehrendorfer [ined.] in Beadle (1984). It was referred to as 'Parahebe sp. $\mathrm{F}^{\prime}$ in Jacobs \& Pickard (1981).

Selected Specimens: New South Wales: Northern Tablelands: Lower slopes of Mt Capoompeta, c. 12 miles [19 km] NE of Deepwater, Constable, 24 Aug 1966 (NSW 99813); $3.1 \mathrm{~km}$ ENE of Emmaville, Coveny 14643, Makinson \& Quirico, 12 Oct 1990 (NSW, BRI); Tent Hill, Cleland (AD); Glen Elgin-Dundee, Gray 3842, Jan 1956 (CANB); Mt Mitchell, Beckler (MEL); Pheasant Mtn, vicinity of Backwater, Gray 3465, 16 Apr 1956 (CANB); top of range near Backwater, Blakely, McKie $\mathcal{E}$ Boorman, 29 Oct 1929 (NSW 6213); Ben Lomond, Maiden, Dec 1899 (NSW 6218); 6 miles [9.6 $\mathrm{kml}$ E of Guyra, Trapnell A90, 19 Apr 1961 (K); Bald Hills to Guy Fawkes and the summit of Round Mtn, Maiden, Dec 1893 (NSW 6217); Guy Fawkes, Boorman, Dec 1909 (NSW 6216); Ebor Falls, Wissman, Jan 1967 (NSW 96037); Armidale, 6 miles [9.6 km] Glen Innes Rd, Stopford, 7 Nov 1908 (BM); Serpentine R., 30 miles [50 km] ENE of Armidale, Davis, 4 Jan 1941 (NSW 22324); Bullock Ck, Williams, 4 Jun 1967 (NE, CHR, NSW 96611); Snowy Ra., Cathedral Rock Natl Park, Native Dog Ck, Telford 10772, 2 Jan 1989 (CBG, AD, NSW); Gara R., 9 miles [14.5 km] E of Armidale, Williams, Aug 1959 (NE); University of New England grounds, Armidale, Piesse, 26 Oct 1959 (NE); Armidale, Stopford, 1907 (BM); Moona Plains, Walcha, Crawford, Nov 1898 (NSW 6219); Moona, Crawford, Feb 1885 (MEL 21587); head of Macleay R., Betche, (NSW 6212); New England, Moore, c. 1867 (K), 1868 (BM). North Western Slopes: Howell, Boorman, June 1904 (NSW 6215); Tingha, Cambage 973, 14 Oct 1903 (NSW 6214).

\section{Derwentia perfoliata (R. Br.) Raf.}

\section{Rafinesque (1836: 55).}

BASIONYM: Veronica perfoliata R. Br. (Brown 1810: 434).

Type: New South Wales: Central Tablelands: Nova Cambria Australis, Blue Mountains', E.F. Barrallier, 1802; lecto BM, photo NSW. From the two sheets of the collection in BM, the left-hand specimen on the sheet marked 'Specimen selected by Brown "for the public collection" ' is selected as lectotype.

Parahebe perfoliata (R. Br.) B. Briggs \& Ehrend. (1968: 742). 


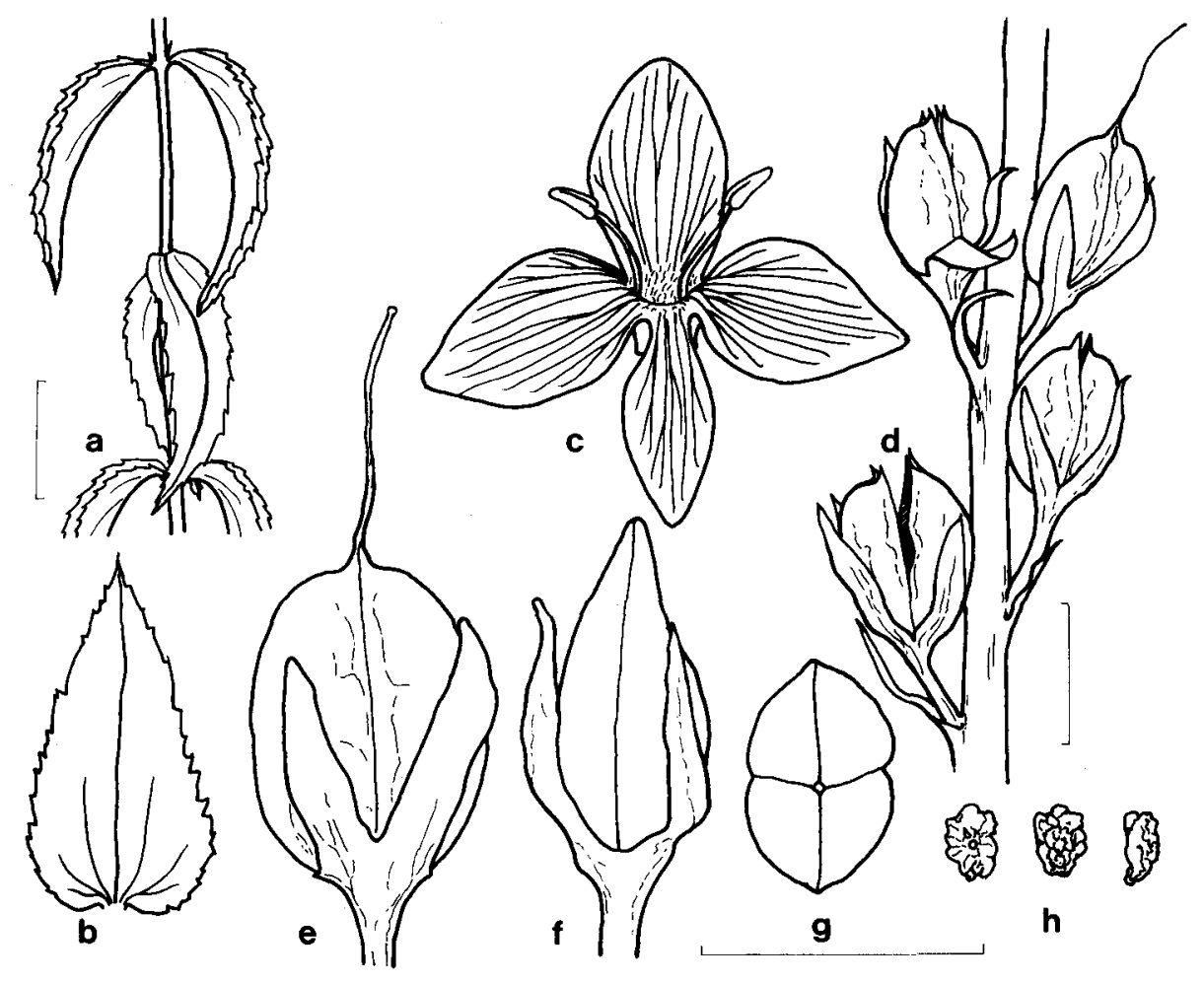

Figure 18. D. arcuata. a, leafy branch; $\mathbf{b}$, corolla with stamens; $c$, part of fruiting inflorescence; d-f, capsule with calyx - lateral, abaxial and apical views; $g$, seeds - adaxial, abaxial and side views; a-f from Ford NSW 42793 (holotype); g MEL 21587. Scale bars: $\mathrm{a}=2 \mathrm{~cm}, \mathrm{~b}=5 \mathrm{~mm}, \mathrm{c}=$ $2 \mathrm{~mm}, \mathrm{e}-\mathrm{g}=2.5 \mathrm{~mm}$.

Veronica imperfoliata Benth. in Candolle (1846: 463). TYPE: New SOUTH WALEs: Central Tablelands: Blue Mountains, New Holland, R. Cunningham; holo K.

Softly woody shrub $0.3-1.2 \mathrm{~m}$ tall, vegetative parts and calyx glabrous and glaucous; the stems, the margins and the nerves of the leaves, and the calyx margins often redpurple. Stems several or numerous, from a narrow woody rootstock or usually the basal $10-30 \mathrm{~cm}$ of the stems prostrate and subterranean (and with adventitious roots) forming ramifying clumps connected by woody rhizomes. Stems mostly erect and unbranched below the inflorescence, rarely with leafy lateral shoots bearing both terminal and lateral racemes, at first herbaceous but becoming softly woody, 30-120 $\mathrm{cm}$ long, terete, 2-4 mm diam., the longest internodes (1.5-)3-7 cm long, each stem flowering in only one season before dying back to the base. Leaves opposite or rarely in whorls of 3 , sessile, coriaceous, ovate or broad-ovate or less often very narrowovate, (16-)25-55(-75) $\mathrm{mm}$ long, (6-)15-40(-65) $\mathrm{mm}$ broad, entire or crenulate or with up to $10(-20)$ shallow or coarse acute teeth on each side, the base perfoliate or cordate or cuneate, the apex acute or acuminate, leaf index 1.06-8, dentation index 1-1.3, the margin thickened, with (3-)5-9 nerves from near the base. Racemes single or opposite at each of 3-6 upper nodes, floriferous portion, 10-45 cm long, with (9-)25-70(-130) 
flowers; the peduncle 5-12 cm long. Bracts linear, subacute, $2-5 \mathrm{~mm}$ long, $0.5-1 \mathrm{~mm}$ broad. Pedicels (3-)5-12 $\mathrm{mm}$ long in fruit. Calyx lobes linear, subacute, 3-5 mm long, $0.5-1 \mathrm{~mm}$ broad. Corolla $7-12 \mathrm{~mm}$ long, blue or purplish blue, the throat with hairs $0.5-1 \mathrm{~mm}$ long; adaxial lobe ovate or broad-ovate, obtuse, $4.5-8 \mathrm{~mm}$ broad; abaxial lobe elliptic or ovate, acute, $2.5-3.5 \mathrm{~mm}$ broad. Stamen filaments purplish-blue or white, 2.5-5 mm long; anthers white or pale yellow, 1.5-3 mm long. Ovules crowded on a narrow vertical placenta. Capsules, not glossy, narrow- or broad-ovoid, obtuse or acute, usually scarcely compressed, $4.5-8.5 \mathrm{~mm}$ long, $2.8-3.5 \mathrm{~mm}$ broad, $2.2-3.5 \mathrm{~mm}$ thick, glabrous, dehiscing by a septicidal split which eventually reaches almost to the base and a loculicidal split for c. 1/2 the distance to the base; style 4-6 mm long, usually persistent, the basal 1-1.5 $\mathrm{mm}$ usually thickened and splitting longitudinally with the capsule. Seeds 6-12, 1-2 mm long, c. $1 \mathrm{~mm}$ broad. Chromosome number (Fig. 1g): $n=20$. (Fig. 4f, 20).

Distribution and habitat: In New South Wales on the South Coast, Central and Southern Tablelands and the Western Slopes, in Victoria in montane areas as far west as c. $144^{\circ} \mathrm{E}$ (Brisbane Ranges). The species is more common above $500 \mathrm{~m}$ alt than at low altitudes and extends to about $1750 \mathrm{~m}$ alt. In eucalypt forests and woodland, alpine meadows, heath, and on rock screes; on a wide range of rock types but usually on shallow skeletal soil. It is reported from granite, shale, sandstone, limestone, and serpentine areas. It commonly adjoins $P$. derwentiana but occurs in drier sites; for example the latter may be on deeper soil or in shaded sites while P. perfoliata grows on adjacent steep, exposed rocky slopes. This wide ecological range contrasts with reports that it was considered 'a sure indicator of gold', a view which was associated with its common name 'Diggers' Speedwell'. The species shows great variation in leaf shape and in this it exhibits some geographic regularity. Plants in drier regions mostly have narrower leaves than those in moister and cooler areas. (Fig. 19).

Richardson \& Barnsley (1991) record a putative hybrid D. derwentiana x D. perfoliata as a self-sown plant in the Australian National Botanic Gardens at Canberra. This plant shows about $70 \%$ of visually normal pollen grains, a somewhat lower percentage than observed in the relevant species, and has well-developed capsules. Its very broad ovate-deltoid leaves that have numerous shallow teeth, together with the shape of corolla lobes and the widely spaced flowers, suggest such a hybrid ancestry. No hybrids between these or other Derwentia species have been recorded in the wild, but ecological differences generally separate the parental species (with $D$. perfoliata in drier sites), despite broad geographic overlap. The plant has some similarities to $D$. derwentiana subsp. maideniana, but Richardson and Barnsley are probably correct in ascribing its origin to interspecific hybridisation.

Selected specimens: New South W Wles: South Coast: Belowra, $40 \mathrm{~km} \mathrm{~W}$ of Narooma, Briggs 3096 , 16 Dec 1969 (NSW, CANB); near Mt Imlay trig, Taylor 224 \& James, 15 Feb 1984 (NSW, MEL). Central Tablelands: Cherry Tree Hill, near Ilford, Ehrendorfer 8801, Briggs \& Johnson, 23 Oct 1966 (NSW 98357, AD, CANB, CHR, MO); Running Stream near Ilford, Burgess, 13 Apr 1963 (CBG); dry rocky summits of hills in the country on the west of the Blue Mountains - Bathurst etc., $A$. Cunningham, April 1817 (K); 3 km S of Lithgow, Briggs 1004 \& Johnson, 26 Nov 1966 (NSW); Mt Victoria, Fletcher, 5 Jan 1892 (NSW 6103); Gibbergunyah Ck, Mittagong, Constable 6722, 20 Feb 1966 (NSW, K); $3 \mathrm{~km} \mathrm{~N}$ of Wombeyan Caves, Briggs 1113 \& Johnson, 29 Nov 1966 (NSW, AD, K, MEL); summit of 'The Gib', Bowral, Rodway, 15 Dec 1935 (NSW 22331); Black Bobs Ck, 7 miles [11 km] SW of Moss Vale, Burgess, 29 May 1962 (CBG). Southern Tablelands: Currockbilly Mtn, near Braidwood, Boorman, Dec 1915 (NSW 6101); Black Mtn, Beeton, 2 Dec 1964 (CBG); Mt Franklin, ACT, Gauba, 2 Nov 1949 (GAUBA); Gingera gate, Brindabella Ra., Canning 639, Jan 1968; below Mt Gingera, ACT, Ford, 16.1.1954 (NSW 26567); between Pryors Hut and Mt Ginni, Brindabella Ra., Coveny 11543 \& Hind, 19 Jan 1983 (NSW, CANB, BRI); Tinderry Mtns, 12 km E of Michelago, Briggs, 26 Dec 1965 (NSW 89773, AD, CBG); near Big Badja Hill, Kybeyan Ra., Coveny 2824 \& Pickard, 15 Mar 1970 (NSW, AD, CHR, K, L, LE, MEL, MO); above Tuross Falls, 
Fairley-Cunninghame, 26 Dec 1967 (NSW); 3 km W of Tuross Falls, Johnson, 5 Jan 1968 (NSW 85491); Sawpit Ck, Mt Kosciusko, Maiden, Jan 1898 (NSW 6114). Central Western Slopes: Upper Meroo R., 14 miles [22.5 km] SW of Mudgee, Johnson E Constable, 13 Aug 1950 (NSW 16199); Ardlethan, Boorman, Nov 1917 (NSW 6130); Harvey Ranges, Peak Hill, Boorman, Nov 1905 (NSW 6120). South Western Slopes: Burrinjuck, Boorman, Feb 1911 (NSW 6098, RSA, US). VICTORIA: Riverina: Chiltern, Williamson, Nov 1904 (MEL). Midlands: S side of Granya Gap, Rodd 606, 16 Apr 1968 (NSW); Avoca, Walter, Oct 1888 (MEL); N end of Brisbane Ra., c. 10 miles [16 km] NW of Balliang, Melville 71.836, 21 Oct 1971 (K, NSW); Brisbane Ranges, Stony Ck Picnic Reserve, Conn 2494 \& Foreman, 16 Nov 1986 (NSW, G, L, MEL, MO, PE, W). Eastern Highlands: Howqua R., Whaite, 11 Jan 1949 (NSW 7655); Wellington R., Gippsland, Lucas, Dec 1890 (NSW 6108); SE of Tali Karng near The Sentinels, Muir 2999, 1 Jan 1964 (MEL). Snowfields: Mt Buffalo, Walter, Nov 1891 (BRI); Suggan Buggan Ra., 4 miles [6.4 km] N of Suggan Buggan, Coveny 2760 \& Pickard, 12 Mar 1970 (NSW, MEL, BRI); Little R., Wulgulmerang, Melville 3013 \& Wakefield, 20 Jan 1953 (K, NSW); W Tree Ck, Murrindal, 13 miles [21 km] N of Buchan, Constable 5368, 30 Oct 1964 (NSW).

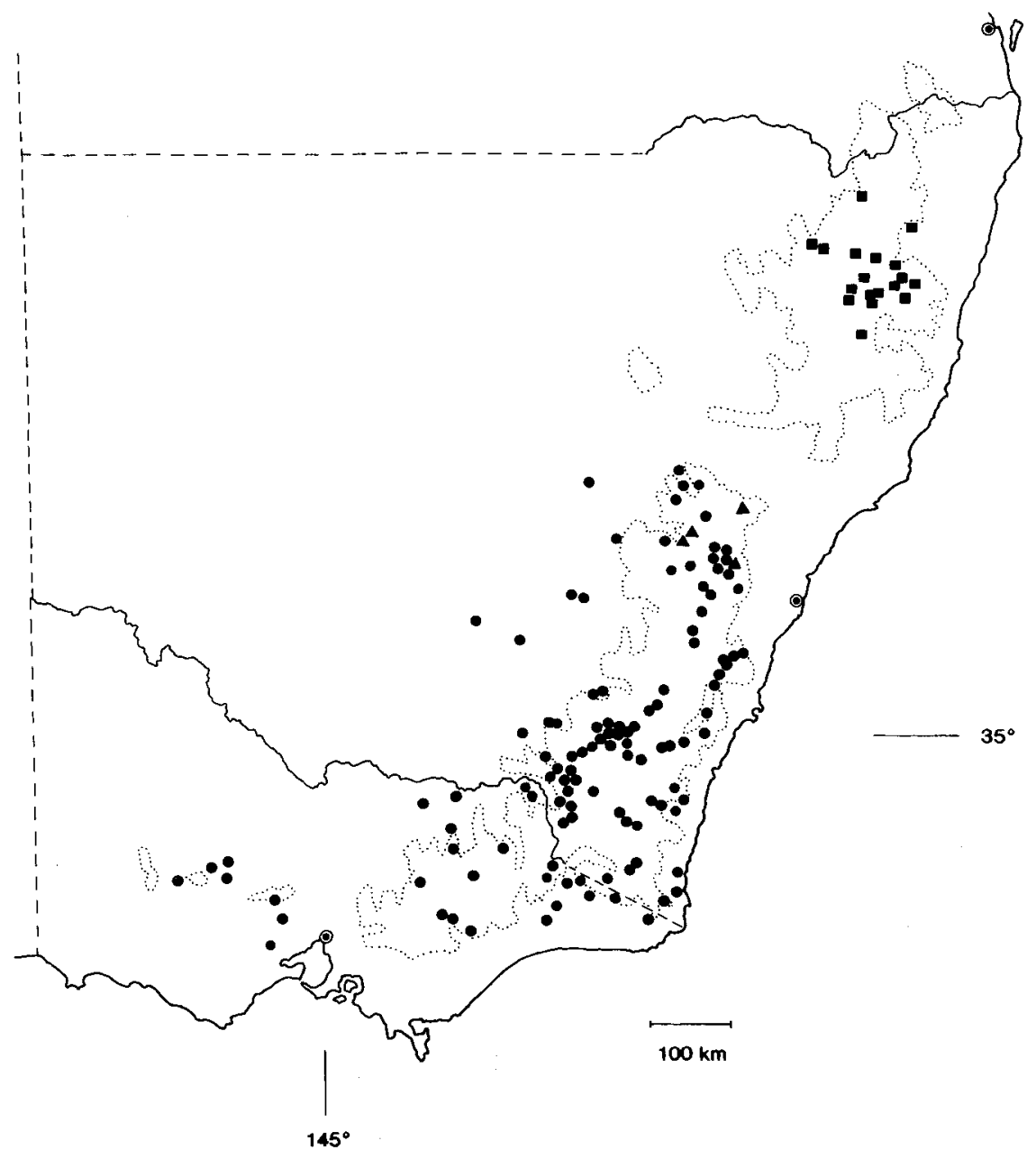

Figure 19. Distribution of $D$. blakelyi $(\boldsymbol{\Lambda}), D$. arcuata $(\boldsymbol{\bullet}), D$. perfoliata $(\bullet)$. The dotted line shows the $610 \mathrm{~m}($ c. $2000 \mathrm{ft})$ contour. 


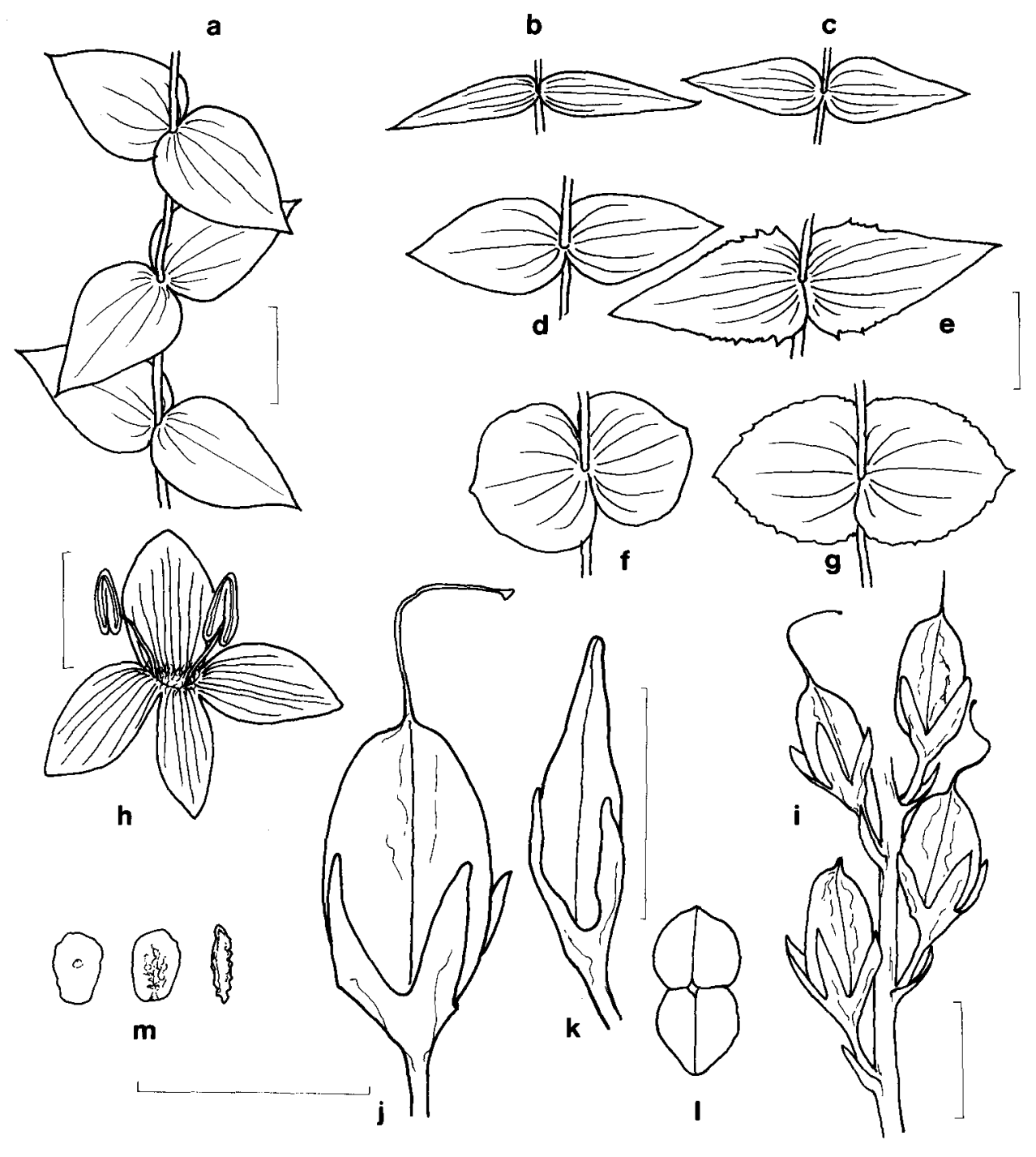

Figure 20. $D$. perfoliata. $\mathbf{a}$, leafy branch; $\mathbf{b}-\mathbf{g}$, variation in leaf shape; $\mathbf{h}$, corolla with stamens; $\mathbf{i}$, part of fruiting inflorescence; $\mathbf{j}-\mathbf{l}$, capsule with calyx - lateral, abaxial and apical views; $\mathbf{m}$, seeds - adaxial, abaxial and side views; a and i-m Briggs NSW 89773; b NSW 6131; c Fairley-Cunninghame NSW 98358; d NSW 989773; e Briggs 1004 \& Johnson; f Ford NSW 26567; g Canning 639. Scale bars: $\mathrm{a}-\mathrm{g}=2 \mathrm{~cm}, \mathrm{~h}=5 \mathrm{~mm}, \mathrm{i}=2 \mathrm{~mm}, \mathrm{j}-\mathrm{m}=2.5 \mathrm{~mm}$. 


\section{Acknowledgements}

We wish to thank the many people and organisations that have assisted this study. Sir Otto Frankel provided chromosomal information and was instrumental in arranging assistance from CSIRO for F.E. to visit Australia at the start of this study. Dr Philip Garnock-Jones generously provided important unpublished information and discussed aspects of the taxa. Dr Lawrie Johnson contributed greatly through discussions, by reviewing the manuscript, and with the cladistic analysis to which reference is made. Mr Robert Makinson, now of CBG, gave great assistance in the organisation of the manuscript. Information and/or collections were provided by Kerry Barringer, W.R. (Bill) Barker, Alex Buchanan, Robert Coveny, Lawrie Johnson, Anthony Rodd, William Stearn, David Symon, John Williams and the late Hansjoerg Eichler, Ernest Constable and Betty Phillips. Thanks are due to the Directors of the following herbaria for the opportunity to study collections and in some cases for their forbearance with regrettably protracted loans: AD, BM, BRI, CANB, CBG, CHR, F, HO, K, MEL, MO, NY, RSA, UNE, US. We are grateful for technical help given at various stages by Ann Williams, Kate Green, Louisa Murray, Robert Makinson and Barbara Wiecek, for SEM observations of pollen provided by Anthony Martin, assistance with illustrations by Angela Schimann (née Clausen) and Marion Westmacott, comment on the manuscript by Bill Barker, Karen Wilson and Peter Wilson, and typing by Angela Benn.

\section{References}

Andrews, H.C. (1808) The botanist's repository, vol. 8.

Allan, H.H. (1961) Flora of New Zealand, vol. I. (Govt Printer: Wellington).

Ashwin, M.B. (1961a) Pygmea. Pp. 870-875 in H.H. Allan, Flora of New Zealand, vol. I. (Govt Printer: Wellington).

Ashwin, M.B. (1961b) Parahebe. Pp. 876-885, 974 in H.H. Allan, Flora of New Zealand, vol. I. (Govt Printer: Wellington).

Ashwin, M.B. (1961c) Hebe 'Flagriformes'. Pp. 927-937 in H.H. Allan. Flora of New Zealand vol. I. (Govt Printer, Wellington).

Barker, W.R. (1986) Scrophulariaceae. Pp. 1275-1313 in J.P. Jessop \& H.R. Toelken (eds), Flora of South Australia. (Govt Printer: Adelaide).

Beadle N.C.W. (1984) Students flora of north eastern New South Wales, part 5. (Univ. New England: Armidale).

Beadle, N.C.W., Evans, O.D. \& Carolin, R.C. (1963) Handbook of the vascular plants of the Sydney district and Blue Mountains. (Brown Gem Print: Armidale).

Beadle, N.C.W., Evans, O.D. \& Carolin, R.C. (1982) Flora of the Sydney Region, edn. 3. (Reed: Sydney).

Beuzenberg, E.J. \& Hair, J.B. (1983) Contributions to a chromosome atlas of the New Zealand flora - 25. Miscellaneous species. New Zealand J. Bot. 21: 13-20.

Borgmann, E. (1964) Anteil der Polyploiden in der Flora des Bismarckgebirges von Ostneuguinea. Zeitschr. Bot. 52: 118-173.

Briggs, B.G. \& Ehrendorfer, F. (1968) New combinations in Parahebe (Scrophulariaceae). Taxon 17: 742 .

Briggs, B.G. \& Ehrendorfer, F. (1976) Chionohebe, a new name for Pygmea Hook. f. (Scrophulariaceae). Contr. Herb. Australiense 25: 1-4.

Briggs, B.G. \& Ehrendorfer, F. (1986) Parahebe decorosa. P. 1301 in J.P. Jessop \& H.R. Toelken (eds), Flora of South Australia. (Govt Printer: Adelaide).

Briggs, B.G. \& Johnson, L.A.S. (1979) Evolution in the Myrtaceae - evidence from inflorescence structure. Proc. Linn. Soc. New South Wales 102: 157-256.

Briggs, B.G. \& Makinson, R.O. (1992) Parahebe, Derwentia. Pp. 588-591 in G.J. Harden (ed.) Flora of New South Wales, vol 3. (New South Wales University Press: Sydney). 
Briggs, J.D. \& Leigh, J.H. (1988) Rare or threatened Australian plants. Australian National Parks \& Wildlife Service, Special Publication no. 14.

Brown, R. (1810) Prodromus florae novae hollandiae.

Burbidge, N.T. \& Gray, M. (1970) Flora of the Australian Capital Territory. (Australian National University Press: Canberra).

Candolle, A.P. de (1846) Prodromus systematis naturalis regni vegetabilis, vol. 10.

Carlquist, S. (1988) Comparative wood anatomy. (Springer-Verlag: Berlin).

Chalk, D. (1988) Hebes and parahebes. (Christopher Helm: London).

Cheeseman, T.F. (1914) Illustrations of the New Zealand flora. (Govt Printer: Wellington).

Cockayne, A.H. (1929) New combinations in the genus Hebe. Trans. \& Proc. New Zealand Inst. 60: $465-472$.

Corner, E.J.H. (1976) The seeds of dicotyledons, vol. 1. (Cambridge University Press).

Cronquist, A. (1981) An integrated system of classification of flowering plants. (Columbia University Press).

Curtis, W.M. (1967) The student's flora of Tasmania, vol. 3 (Govt Printer: Hobart).

Dahlgren, G. (1989) The last Dahlgrenogram - system of classification of the dicotyledons. Pp. 249-260 in K. Tan (ed.), The Davis \& Hedge Festschrift: plant taxonomy, phytogeography and related subjects. (Edinburgh University Press).

Dahlgren, R.M.T., Rosendal-Jensen, S., \& Nielsen, B.J. (1981) A revised classification of the Angiosperms with comments on correlation between chemical and other characters. Pp. 149-204 in D.A. Young \& D.S. Seigler (eds), Phytochemistry and angiosperm phylogeny. (Praeger: New York).

David, T.W.E. (1950) The geology of the Commonwealth of Australia, vol. 2. (Edward Arnold: London).

Delph, L.F. (1990). The evolution of gender dimorphism in New Zealand Hebe (Scrophulariaceae) species. Evol. Trends Plants 4: 85-97.

Ehrendorfer, F. (1971) Discussion. Pp. 150-151 in P.H. Davis et al. (eds), Plant life of South-West Asia. (Bot. Soc. Edinburgh: Aberdeen).

Farris, J.S. (1988). Hennig86 reference, version 1.5. - New York: published by the author.

Frankel, O.H. (1941) Cytology and taxonomy of Hebe, Veronica \& Pygmaea. Nature 147: 117-118.

Frankel, O.H. \& Hair, J.B. (1937) Studies on the cytology, genetics and taxonomy of New Zealand Hebe and Veronica (part 1). New Zealand J. Sci. Technol. 18: 669-687.

Gandoger, M. (1919) Sertum plantarum novarum, pars secunda. Bull. Soc. Bot. France 66: 216307.

Garnock-Jones, P.J. (1976). Breeding systems and pollination in New Zealand Parahebe (Scrophulariaceae). New Zealand J. Bot. 14: 291-298.

Garnock-Jones, P. (1989) What is Leonohebe? Hebe News 4:19-22.

Garnock-Jones, P. (1991) An introduction to cladistics, with examples from Hebe (Scrophulariaceae). Austral. Syst. Bot. Soc. Newsletter 69: 10-11.

Garnock-Jones, P.J., Briggs, B.G. \& Ehrendorfer, F. (1990) Proposal to conserve 7579a Parahebe W. Oliver against Derwentia Raf. Taxon 39: 536-537.

Garnock-Jones, P.J. \& Langer, H.J. (1980) Parahebe catarractae (Scrophulariaceae) : infraspecific taxonomy. New Zealand J. Bot. 18: 285-298.

Grayer-Barkmeijer, R.J. (1973) A chemosystematic study of Veronica: iridoid glucosides. Biochem. Syst. 1: 101-110.

Grayer-Barkmeijer, R.J. (1978) Flavonoids in Parahebe and Veronica: a chemosystematic study. Biochem. Syst. Ecol. 6: 131-137.

Grimes, J. (1992) Metamerism, heterochrony, and inflorescence morphology of the Pithecellobiumcomplex (Leguminosae: Mimosoideae: Ingeae). Brittonia 44: 140-159.

Hair, J.B. (1967) Contributions to a chromosome atlas of the New Zealand flora - 10. Hebe (Scrophulariaceae). New Zealand J. Bot. 5: 322-352.

Hair, J.B. (1970) Contributions to a chromosome atlas of the New Zealand flora - 13. Parahebe and Pygmaea (Scrophulariaceae). New Zealand J. Bot. 8: 255-259.

Hamann, U. (1958) Morphologische und histogenetische Studien an Veronica-Arten. Bot. Jahrb. Syst. 78: 69-118.

Hamann, U. (1960) Morphologische Beobachtungen an Hebe diosmifolia (Scrophulariaceae), besonders ihren Infloreszenzen. Bot. Jahrb. Syst. 79: 405-427.

Heads, M.J. (1987) New names in New Zealand Scrophulariaceae. Bot. Soc. Otago Newsletter 5 : 
$4-11$.

Hong, D. (1984) Taxonomy and evolution of the Veroniceae (Scrophulariaceae) with special reference to palynology. Opera Bot. 75: 5-60.

Hooker, J.D. (1844) Veronica nivea Hook. fil. t. 640 in W.J. Hooker, Icones plantarum, ser. 2: 7.

Hutchins, G. (1990) Parahebe formosa. Hebe News. 5: 11-12.

Jacobs, S.W.L. \& Pickard, J. (1981) Plants of New South Wales. (Govt Printer: Sydney).

Johnson, L.A.S. \& Briggs, B.G. (1984) Myrtales and Myrtaceae - a phylogenetic analysis. Ann. Missouri Bot. Gard. 71: 700-756.

Lindley, J. (1842) Miscellaneous matter of the Botanical Register. Edwards's botanical register n.s. 2: $1-86$.

Loudon, J.C. (1830) Hortus britannicus.

Metcalfe, C.R., \& Chalk, L. (1950) Anatomy of the dicotyledons. (Clarendon Press: Oxford).

Moore, C., \& Betche, E. (1893) Handbook of the flora of New South Wales.

Moore, L.B. (1961) Hebe, except 'Flagriformes'. Pp. 885-952 in H.H. Allan, Flora of New Zealand, vol. I. (Govt Printer: Wellington).

Moore, L.B. (1967) How to look at Hebe. Tuatara 15: 10-15.

Moore, L.B. \& Edgar, E. (1970) Flora of New Zealand, vol. II. (Govt Printer: Wellington).

Mueller, F. (1853) Diagnoses et descriptiones plantarum novarum, quas in Nova Hollandia australi praecipue in regionibus interioribus. Linnaea 25: 367-445.

Oliver, W.R.B. (1944) The Veronica-like species of New Zealand. Rec. Domin. Mus. 1: 228-231.

Ollier, C.D. (1986) The origin of alpine landforms in Australasia. Pp. 3-26 in B.A. Barlow (ed.), Flora and fauna of alpine Australasia. (CSIRO: Melbourne).

Rafinesque, C.S. (1836) Flora telluriana, pt 4.

Raman, S. (1987) A code proposed for the classification of trichomes as applied to the Scrophulariaceae. Beitr. Biol. Pflanzen 62: 349-367.

Richardson, M.M. \& Barnsley, N. (1991) Catalogue of living plants, Australian National Botanic Gardens. (Australian National Botanic Gardens: Canberra).

Royen, P. van, (1972) The Scrophulariaceae of the alpine regions of New Guinea. Bot. Jahrb. Syst. 91: 383-437.

Royen, P. van, \& Ehrendorfer, F. (1970) New combinations in Parahebe (Scrophulariaceae). Taxon 19: 483.

Stones, M. \& Curtis, W.M. (1969) The endemic flora of Tasmania, vol. 2 (Ariel Press: London).

Sutton, D.A. (1988) A revision of the tribe Antirrhineae. (British Museum/Oxford University Press).

Thieret, J.W. (1967) Supraspecific classification in the Scrophulariaceae: a review. Sida 3: 87-106.

Thorne, R.F. (1992) An updated phylogenetic classification of the flowering plants. Aliso 13: 365389.

Weberling, F. (1981) Morphologie der Blüten und der Blütenstande. (Ulmer: Stuttgart).

Yamazaki, T. (1957) Taxonomical and phylogenetic studies of Scrophulariaceae-Veroniceae with special reference to Veronica and Veronicastrum in Eastern Asia. J. Fac. Sci. Univ. Tokyo, Sect. 3, Bot. 7: 91-162. 